Biochemical Journal: this is an Accepted Manuscript, not the final Version of Record. You are encouraged to use the Version of Record that, when published, will replace this version. The most up-to-date version is available at http://dx.doi.org/10.1042/BCJ20190275. Please cite using the DOI 10.1042/BCJ20190275

B-vitamin mediated gene regulation in vascular smooth muscle cells

\title{
Folate deficiency promotes differentiation of vascular smooth muscle cells without affecting the methylation status of regulated genes
}

\author{
Andreas F Kolb ${ }^{1,4}$, Linda Petrie ${ }^{1}$, Claus D Mayer ${ }^{2}$, Lynn Pirie ${ }^{1}$, Susan J Duthie ${ }^{1,3}$ \\ ${ }^{1}$ Metabolic Health Group, Rowett Institute, University of Aberdeen, ${ }^{2}$ Biomathematics and \\ Statistics Scotland (BioSS), University of Aberdeen, ${ }^{3}$ School of Pharmacy and Life Sciences \\ Robert Gordon University
}

author addresses:

1 Andreas Kolb, Linda Petrie, Lynn Pirie

The Rowett Institute

University of Aberdeen

Foresterhill

Aberdeen, AB25 2ZD, UK

e-mail: L.Petrie@abdn.ac.uk, L.Pirie@abdn.ac.uk

2 Claus D Mayer

Biomathematics and Statistics Scotland

University of Aberdeen

Foresterhill

Aberdeen, AB25 2ZD, UK

e-mail: c.mayer@abdn.ac.uk

3 Susan Duthie

School of Pharmacy and Life Sciences

The Robert Gordon University

Riverside East, Garthdee Road

Aberdeen, AB10 7GJ, UK

e-mail: s.j.duthie@rgu.ac.uk

\section{4 corresponding author \\ Dr Andreas Kolb \\ Metabolic Health Group \\ The Rowett Institute \\ University of Aberdeen \\ Foresterhill \\ Aberdeen, AB25 2ZD, UK \\ phone: 0044-1224-438645 \\ e-mail: a.kolb@abdn.ac.uk}

running title: B-vitamin mediated gene regulation in vascular smooth muscle cells 


\begin{abstract}
Elevated serum homocysteine, an intermediate of cellular one-carbon metabolism, is an independent risk factor for cardiovascular disease (CVD). Folate deficiency increases serum homocysteine and may contribute to CVD progression. Vascular smooth muscle cells regulate vascular contractility, but also contribute to repair processes in response to vascular injury. Nutritional deficiencies, like folate deficiency, are thought to impact on this phenotypic plasticity, possibly by epigenetic mechanisms.

We have investigated the effect of folate deficiency on vascular smooth muscle cells in two cell culture systems representing early and late stages of smooth muscle cells differentiation. We find that folate deficiency promotes differentiation towards a more contractile phenotype as indicated by increased expression of respective marker genes. However, microarray analysis identified markers of striated muscle as the predominant gene expression change elicited by folate deficiency. These changes are not merely a reflection of cell cycle arrest, as foetal calf serum restriction or iron deficiency do not replicate the gene expression changes observed in response to folate deficiency. Folate deficiency only has a marginal effect on global DNA methylation. DNA methylation of CpG islands associated with genes regulated by folate deficiency remains unaffected. This supports our earlier findings in a mouse model system which also did not show any changes in global DNA methylation in response to folate and vitamin B6/B12 deficiency.

These data suggest that folate deficiency enhances the expression of smooth muscle marker gene expression, promotes a shift towards a skeletal muscle phenotype, and does not regulate gene expression via DNA methylation.
\end{abstract}

\title{
Keywords
}

B-vitamins, folate, vascular smooth muscle cells, DNA methylation, gene regulation

\section{Abbreviations}

cardiovascular disease: CVD, estrogen receptor alpha: ER $\alpha, \mathrm{Hcy}$ : homocysteine, MTHFR: methylene-tetra hydro folate reductase, RIA: radio-immuno assay, 


\section{Introduction}

Hyperhomocysteinemia is a risk factor for all facets of atherosclerotic disease including stroke, coronary heart disease and peripheral artery disease [1]. Homocysteine is generated as an intermediate of cellular one carbon metabolism. Folate (also known as vitamin B9), vitamin B6 and vitamin B12 are all essential components of cellular one carbon metabolism, either as substrate or as enzyme co-factors (Fig. 1). Single nucleotide polymorphisms or mutations of genes involved in one carbon metabolism are significant predictors of vascular disease. In general a lower activity of these enzymes (e.g. MTHFR, methionine synthase or cystathionine-b-synthase) is associated with a higher risk of vascular disease [2-5].

At present it is unclear whether homocysteine acts as a direct promoter of cardiovascular disease or whether it is mainly an indicator of low B-vitamin status. Numerous studies in animal model systems have assessed the potential mechanisms by which homocysteine might directly influence cardiovascular disease risk [6]. These experiments typically used diets deficient in folate, vitamin B6 and B12 and rich in methionine $[7,8]$ or drinking water enriched with methionine or homocysteine [9]. Some of these studies have indeed demonstrated that indicators of vascular disease respond directly to serum homocysteine concentrations [10-12]. However, in other studies an increase in serum homocysteine was unrelated to the formation of cardiovascular lesions, whereas a reduction in serum B-vitamin levels was $[7,8,13,14]$. This suggests that B-vitamin deficiency may promote cardiovascular disease risk by mechanisms other than causing hyperhomocysteinemia. This is further supported by findings from several large-scale human intervention trials $[15,16]$ using supplementation regimes containing folate, B6 and B12 [16]. Typically supplementation of patients with folate and B-vitamins was successful in reducing serum homocysteine, but ineffective in preventing cardiovascular mortality [15]. This suggests that the major value of homocysteine may be as a marker of B-vitamin deficiency, rather than a mechanistic agent in vascular disease development.

One alternative hypothesis explaining the role of B-vitamin deficiency in vascular disease suggests that a lack of methyl groups available for DNA and histone methylation may alter epigenetic gene regulation in the vascular system [17]. Support for this hypothesis comes from animal experiments which show that alterations in folate supply in pregnancy leads to changes in DNA methylation in "metastable" gene alleles and subsequent changes in gene expression and phenotype [18-20]. As these epigenetic mechanisms are important for the maintenance of differentiated phenotypes, it has been suggested that a shortage in dietary methyl donors may impact on the maintenance of the differentiation status of vascular smooth muscle cells and other cell types [21]. Patients with cardiovascular disease, who suffered from hyperhomocysteinemia and were given a folate supplement (15 mg oral methyltetrahydrofolate a day for 8 weeks) showed an increase in the methylation of imprinted genes suggesting that folate supply may influence the DNA methylation status of genes [22].

Vascular smooth muscle cells (VSMC) display a flexible phenotype in that they are, under normal circumstances, quiescent, contractile and do not synthesize extra-cellular matrix or matrix-modifying enzymes $[10,23,24]$. In the context of vascular injury VSMC become mobile, proliferative and secrete extra-cellular matrix proteins, possibly adopting a less differentiated phenotype. In VSMC isolated from New Zealand White rabbits a more proliferative phenotype is associated with a reduction in global DNA methylation $[17,25]$. In human atherosclerotic lesions global DNA methylation is also decreased relative to normal tissue [25]. However, it is unclear, whether this reduction in DNA methylation is a prerequisite for increased proliferation. Alternatively, the most proliferative (and by 
inference, least differentiated) cells in the population of isolated smooth muscle cells may be those with a reduced DNA methylation status.

We have used two in vitro systems of smooth muscle cell differentiation to determine the influence of B-vitamin supply on differentiation status. One model, A404, represents early developmental stages of smooth muscle differentiation and one model, A7r5, represents a partially differentiated state of vascular smooth muscle cell development. We find that folate deficiency impairs cell proliferation, increases homocysteine secretion and only leads to marginal changes in global DNA methylation. B-vitamin deficiency promotes, rather than prevents, the expression of smooth muscle cell marker genes. However, a microarray analysis of folate deficient VSCM suggest a phenotypic shift towards a skeletal muscle phenotype. The DNA methylation status of the deficiency responsive genes is not affected. This suggests that the methylation of $\mathrm{CpG}$ islands in the vicinity of normal genes (in contrast to metastable alleles) is not responsive to B-vitamin status.

\section{Material \& Methods}

\subsection{Cells}

A404 cells [26], a gift of Prof Gary Owens, University of Virginia, are derivatives of the mouse embryonic carcinoma cell line P19. The cells can be differentiated into several lineages, including a smooth muscle cell lineage, in the presence of retinoic acid. The cell line also carries a puromycin resistance gene under the control of the smooth muscle specific myosin heavy chain 11 (MYH11) promoter. Selection of retinoic acid treated cells in medium containing puromycin permits survival of cells which have differentiated towards the smooth muscle cell lineage but removes cells which have differentiated into other lineages (e.g. neuronal). A404 cells were grown in alpha-MEM medium (Sigma, M8042) supplemented with $7.5 \%$ of foetal calf serum (Hyclone), $200 \mu \mathrm{g} / \mathrm{ml}$ glutamine (Life Technologies) and $100 \mathrm{U} / \mathrm{ml}$ penicillin/streptomycin $(50 \mathrm{U} / \mathrm{ml}$ penicillin and $50 \mu \mathrm{g} / \mathrm{ml}$ streptomycin; Life Technologies) and $200 \mu \mathrm{g} / \mathrm{ml}$ hygromycin B (Roche). Cells were split 1:50 every 2 or 3 days and used for experiments up to passage 20. Differentiation of cells was induced by the addition of $1 \mu \mathrm{M}$ all-trans retinoic acid (Sigma) for 3 days. In some experiments retinoic acid treated cells were additionally treated with $0.5 \mu \mathrm{g} / \mathrm{ml}$ puromycin (Invivogen) for another 3 days. Rat A7r5 cells (ECACC catalogue number 86050803) were grown in DMEM (Sigma, D6171) supplemented with $10 \%$ foetal calf serum (Sigma), $2 \mathrm{mM}$ glutamine and penicillin/streptomycin at $37^{\circ} \mathrm{C}$ and $5 \% \mathrm{CO}_{2}$ in a humidified incubator.

In order to generate folate deficient cells, custom made alpha-MEM and DMEM medium was used (BioConcept). The custom-made medium is equivalent to the normal medium but does not contain folic acid, vitamin B6 (pyridoxine- $\mathrm{HCl}$; concentration $4 \mu \mathrm{g} / \mathrm{ml}$ or $23 \mu \mathrm{M}$ in DMEM, $1 \mu \mathrm{g} / \mathrm{ml}$ or $5.9 \mu \mathrm{M}$ in alpha-MEM), vitamin B12 (cobalamin; absent in DMEM, $1.36 \mu \mathrm{g} / \mathrm{ml}$ or $3.4 \mu \mathrm{M}$ in alpha MEM) and methionine $(30 \mathrm{mg} / \mathrm{l}$ or $200 \mu \mathrm{M}$ in DMEM, $15 \mathrm{mg} / \mathrm{l} \mathrm{or}$ $100 \mu \mathrm{M}$ in alpha-MEM), which can be added separately. While normal alpha-MEM contains both, vitamin B6 and B12, DMEM does not contain vitamin B12. However, sufficient amounts of vitamin B12 are contained in foetal calf serum. A reduced folate medium (indicated as $10 \mathrm{~F}$, containing a folate concentration equivalent to human serum) contained $10 \mathrm{ng} / \mathrm{ml}$ of folic acid. A folate deficient medium (indicated as F) contained no folic acid. A medium deficient in folic acid and vitamin B6 and B12 is indicated as FB. All media were used in conjunction with conventional (i.e. non-dialysed) FCS, which contains $0.6 \mathrm{ng} / \mathrm{ml}$ of folate (as determined by radio-immunoassay). The deficient medium therefore allows for a limited level of cell proliferation. Cell numbers were determined by counting in a haemocytometer.

For treatment with azacytidine cells were seeded into $6 \mathrm{~cm}$ dishes in conventional medium (DMEM for A7r5 cells, alpha-MEM for A404 cells). 24h later cells the medium was 
changed to different concentrations of azacytidine (typically $0.1,1,5$ or $10 \mu \mathrm{M}$ ) or control medium. $72 \mathrm{~h}$ later the medium was changed back to control medium. After a further $72 \mathrm{~h}$ cells were counted and genomic DNA was isolated.

\subsection{Biochemistry}

Homocysteine was analysed using isotope dilution GC-MS (gas chromatography and mass spectrometry) largely as described [27]. Briefly, medium was harvested from treated cells. $100 \mu \mathrm{l}$ of medium was mixed with $50 \mu \mathrm{l}$ of a $50 \mathrm{nM}$ C13 labelled homocysteine standard solution and $25 \mu \mathrm{l}$ of a $0.1 \mathrm{M}$ DTT solution and incubated at room temperature for $20 \mathrm{~min}$. After addition of a 2:1 acetonitrile/ethanol solution the reaction was centrifuged at $13000 \mathrm{rpm}$ for $5 \mathrm{~min}$. The supernatant was absorbed to a Strata-X-C spe column (Phenomenex) activated with $1 \mathrm{ml}$ of methanol. The column was washed consecutively with $0.5 \mathrm{ml}$ of water and $0.5 \mathrm{ml}$ of methanol and dried. Homocysteine was eluted into a tube with $700 \mu \mathrm{l}$ of $5 \% \mathrm{NH}_{3}$ in $70 \%$ methanol and dried at $90^{\circ} \mathrm{C}$ under nitrogen. The pellet was treated with $10 \mu \mathrm{l}$ of $0.1 \mathrm{M}$ DTT and $70 \mu \mathrm{l}$ of $2 \mathrm{M} \mathrm{NH}_{3}$ for $30 \mathrm{~min}$. at room temperature and again dried under nitrogen at $90^{\circ} \mathrm{C}$. The dried material was then resuspended in $50 \mu$ l of a 1:1 mix of MTBSTFA [N-Methyl-N-(tert-butyldimethylsilyl)-trifluoroacetamide] and acetonitrile and heated to $90^{\circ} \mathrm{C}$ for $20 \mathrm{~min}$. The tertiarybutyldimethylsilyl (tBDMS) derivative of homocysteine was detected by GCMS analysis on a $30 \mathrm{~m} \times 0.32 \mathrm{~mm} \times 0.25$ micron ZB-5MSi capillary column. Injections $(1 \mu \mathrm{l})$ were made in the split mode with a 25:1 split. The M-57 fragment ions at $\mathrm{m} / \mathrm{z} 420$ and 421 for unlabelled and 1-C13 labelled homocysteine-tBDMS are monitored under electron impact selective ion monitoring conditions (EI-SIM). Concentrations of homocysteine were calculated from peak area ratios obtained from EI-SIM fitted to a LREG curve generated from standards. Homocysteine concentrations are expressed in correlation with cell numbers (as measured by $\mu \mathrm{g}$ of DNA) to evaluate the secretion of homocysteine per cell. Typically, homocysteine concentrations in the medium of cells grown in full medium are higher (around $10 \mu \mathrm{M}$ ) than in the medium of cells grown in deficient medium (around 1-5 $\mu \mathrm{M}$ ). However, the number of cells in the deficient medium is substantially lower.

Folate concentrations were measured using a competitive radio-immuno-assay (RIA) assay (MP Biomedicals - SimulTRAC-S radioassay kit Vitamin Folate $\left[{ }^{125}\right.$ I]; catalogue number: 06B 254932) following the supplier's instructions. Briefly, cultured cells were detached from plates using Trypsin-EDTA and an aliquot of the cells was counted in a haemocytometer. The remaining cells were pelleted by a brief centrifugation and the cell pellet was snap frozen in liquid nitrogen. For analysis the cells were thawed by addition of $500 \mu \mathrm{l}$ of standard A (blank), resuspended by vortexing and sonicated in an ultrasound water bath for $2 \mathrm{~min}$. Cell culture supernatants were measured after diluting $100 \mu \mathrm{l}$ of medium with $400 \mu \mathrm{l}$ of standard A. $1 \mathrm{ml}$ of tracer solution containing DTT was added and the samples were incubated in a boiling water bath for $15 \mathrm{~min}$. The samples were then cooled to room temperature in a water bath. $200 \mu \mathrm{l}$ of antibody beads were added to each sample and incubated at room temperature for 1 hour in the dark. The beads were subsequently pelleted by centrifugation at $4^{\circ} \mathrm{C}$ for 10 min. and the supernatant discarded. The sample tubes were read on a gamma counter (Packard Instruments). The readings were correlated with a standard curve (range between: 1 and 20ng of folate per $\mathrm{ml}$ ) and the folate concentration was correlated with cell number.

\section{3. $R N A$ and quantitative $P C R$}

RNA was isolated using the Trizol reagent (Sigma) following the manufacturer's protocol ( $1 \mathrm{ml}$ of Trizol per $10^{7}$ cells). Reverse transcription of RNA was done using MLV RNAse(-) reverse transcriptase (Promega) following the manufacturer's recommendations. $2 \mu \mathrm{g}$ of total RNA was used as template for the cDNA synthesis reaction. A one in 10 dilution of the CDNA synthesis reaction was subsequently used as template for quantitative PCR 
(Applied Biosystems 7500 Fast System). At least three independent experiments were carried out for each data point and every sample was measured in triplicate.

Quantitative PCR amplifications were carried out with a final primer concentration of $0.5 \mu \mathrm{M}$. Oligonucleotide primers were designed using the Primer BLAST program (NCBI). The sequences, annealing temperatures and amplicon sizes of the oligonucleotides used in this study are provided in table 1. The quantitative PCR products were evaluated by melting point analysis and agarose gel electrophoresis. Amplifications were done at 40 cycles of $15 \mathrm{~s}$ at $95^{\circ} \mathrm{C}, 15 \mathrm{~s}$ at the indicated annealing temperature and $30 \mathrm{~s}$ at $72^{\circ} \mathrm{C}$. Data were collected at the end of each PCR cycle. Standard curves for all genes were generated from serial dilutions of a plasmid containing the cDNA for each gene. The crossing points obtained from the sample analysis was then correlated with the standard curves to provide a concentration of the individual PCR product. Expression of the genes was then correlated with expression of the reference genes ( $\beta$-actin or GAPDH) in the same sample (expressed as $\mathrm{pg}$ of gene per pg of reference) and expressed as fold change from control treatments.

\subsection{Microarray}

RNA for microarrays was isolated from A7r5 cells grown in medium containing $2.5 \mathrm{ng} / \mathrm{ml}, 10 \mathrm{ng} / \mathrm{ml}$ or $100 \mathrm{ng} / \mathrm{ml}$ of folic acid. The isolation was carried out in cells grown for 7,14 or 21 days in the 3 different media ( 3 time points at 3 concentrations). $2.5 \mathrm{ng} / \mathrm{ml}$ reflects a serum concentration typically seen in folate deficiency; $10 \mathrm{ng} / \mathrm{ml}$ represents a folate sufficient status; $100 \mathrm{ng} / \mathrm{ml}$ represents serum folate concentrations seen in response to folic acid supplement intake. 5 independent samples were analysed for each of the 9 experimental points. RNA was isolated using the Trizol reagent (Sigma) following the manufacturer's protocol, treated with RNAse-free DNAsel (Promega) for $30 \mathrm{~min}$. at $37 \mathrm{C}$, extracted with phenol/chloroform and precipitated with ethanol. The quality of the RNA was assessed via the ratio of $O D$ at $260 \mathrm{~nm}$ and $280 \mathrm{~nm}$ (only samples with an OD higher than 1.8 were used) and capillary electrophoresis analysis on Agilent Chips (only RNA with a RIN higher than 8 was used).

Microarray analysis was done on Affymetrix rat 230-2.0 Genechips by ServiceXS. Data from Service XS, in the CEL file format (containing the raw signal intensities) were transferred to the MadMax website (https://madmax.bioinformatics.nl) where data was analysed using the statistical programming language $\mathrm{R}$ [28] and R-libraries offered by the Bioconductor project [29]. The data were normalized using Bioconductor and a GCRMA method, a Robust Multiarray Analysis with correction for the G:C content of the oligos, and then statistically analysed using the Limma package [30], which allowed identification of the most differentially expressed genes between different conditions using a nominal $p$-value $<0.05$ to represent statistical significance. Microarray data were deposited at the NCBI Gene Expression Omnibus under accession number GSE125502.

\subsection{DNA methylation}

Genomic DNA isolation was done using the Promega Wizard kit following the supplier's instructions. For all DNA methylation analyses reference samples were generated which represent methylated and non-methylated DNA. Non-methylated control DNA was generated by whole genome amplification of genomic DNA using a Qiagen Repli-G kit. Methylated DNA was generated by treating isolated genomic DNA with SssI DNA methyl transferase and S-adenosyl methionine (SAM; as substrate) for $1 \mathrm{~h}$ at $37 \mathrm{C}$. Additional enzyme and additional SAM were added after $30 \mathrm{~min}$. The activity of Sssl was monitored using bacteriophage lambda DNA as control (suppl. Fig. 6). BstUl restriction digestion of lambda DNA (which is not methylated) yields a total of 25 DNA fragments. Treatment of lambda DNA with Sssl and SAM fully methylates the phage DNA and prevents digestion with BstUI (recognition sequence CGCG). Different relative amounts of methylated and non- 
methylated DNA were mixed and assayed by LC-MS to establish a standard curve which correlates the percentage of SssI methylated DNA in the mixture and the experimentally determined \% of methylated cytosine residues (suppl. Fig. 8c).

Global DNA methylation was measured using an LC-MS based method developed by

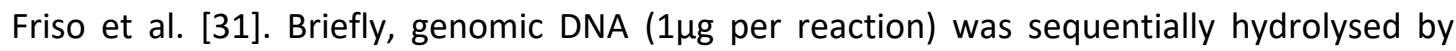
digestion with nuclease P1 (2U per reaction), venom phosphodiesterase I (0.002 U per reaction) and alkaline phosphatase ( $0.5 \mathrm{U}$ per reaction). The resulting hydrolysate was then separated by reverse phase HPLC. The 2'deoxycytidine and 5'methyl-2'deoxycytidine peaks were detected and quantified with reference to the internal standard ${ }^{15} \mathrm{~N}_{3} 2^{\prime}$ deoxycytidine.

Combined bisulfite restriction analysis (COBRA) was carried out as described [32]. Briefly, genomic DNA was treated with bisulfite reagent using the EZ DNA methylation kit (Zymo Research) and purified using the spin columns provided in the kit. The concentration of the converted DNA was measured using a Nanodrop device. $5 \mathrm{ng}$ of bisulfite converted DNA was used as template for a PCR amplification using gene specific primer pairs. The primer pairs were designed using the Methyl Primer Express software (Applied Biosystems). Primer pairs for rat LINE1, rat estrogen receptor alpha exon 1 and rat 14-3-3 sigma (SFN1) were taken from the literature [33-35] (table 2). The amplified DNA was purified over a spin column (QIAGEN Qiaquick) and 100ng of PCR product were used for a digestion with a restriction enzyme whose recognition sequence carries a CG dinucleotide (including BstUI, Taq, SfaNI). Aliquots of the restriction reaction were separated on a $10 \%$ polyacrylamide gel and visualised by ethidium bromide staining. DNA bands were quantified using a Fuji Imaging station and the AIDA Imaging software.

Pyrosequencing primer combinations (PCR primer pairs and sequencing primer) were designed using the Pyromark software package (Qiagen) for the following genes: skeletal muscle myosin heavy chain (MYH2), skeletal muscle $\alpha$-actin (ACTA1), prion protein dublet (PRND), thioredoxin interacting protein (TXNIP) and are shown in table $\mathbf{3}$. Analysis kits for the Insig1 (insulin induced gene 1; PM00547638), Id1 (inhibitor of DNA binding 1; PM00543697) and Idi1 (isopentenyl-diphosphate delta isomerase; PM00504119) genes were purchased from Qiagen. Bisulfite treated DNA was used for the PCR reaction at a concentration of $10 \mathrm{ng} / \mu \mathrm{l}$. Pyrosequencing was carried out using the Pyromark Gold Q24 reagents following the supplier's instructions.

\subsection{Protein analysis}

Cytoplasmic protein extracts for Western blot analysis were prepared as described [36]. Briefly, cells were lysed on ice in a buffer containing $25 \mathrm{mM} \mathrm{KPO}_{4} \mathrm{pH} 7.8,8 \mathrm{mM} \mathrm{MgCl}_{2}$, $1 \mathrm{mM}$ EDTA, 1\% Triton X-100 and 15\% glycerol. The extracts were incubated on ice for $5 \mathrm{~min}$. and then centrifuged at $4^{\circ} \mathrm{C}$ for $1 \mathrm{~min}$. at $10000 \mathrm{~g}$. The supernatants were then aliquoted and stored at $-80^{\circ} \mathrm{C}$.

Western blot analyses were carried out after semi-dry transfer of the proteins to a nitrocellulose membrane as described [37]. Smooth muscle $\alpha$-actin (ACTA2, 42kDa) and $\beta$ actin (ACTB, 42kDa) were detected using monoclonal antibodies (Sigma A2547 and A5441, respectively) and a horse-radish-peroxidase linked anti-mouse serum (Cell Signalling Technologies \#7076). All antibodies were used at a dilution of 1:1000. Western blots were developed using a chemiluminescent detection kit (Pierce) and the light emission recorded on a Fuji Imaging Station.

Immunohistochemistry was carried out as previously described [37].

\subsection{Statistical analysis}

Statistical analysis of datasets was done using one or two-way ANOVA in Microsoft Office Excel 2016 and post-hoc analysis and t-tests were carried out Graph-Pad Prism. Error bars indicate standard deviations. The number of replicates is indicated for each figure. The 
significance levels indicated in the figures typically refer to the comparisons between the control medium and the modified media. Principal components analysis was done using the prcomp function in $\mathrm{R}$ applied to scaled data, i.e. using the correlation matrix rather than the covariance matrix. Pathway analysis was carried out using the Bioconductor-TopGo (https://rdrr.io/bioc/topGO/), DAVID (https://david.ncifcrf.gov/) and ENRICHR (http://amp.pharm.mssm.edu/Enrichr/) software packages.

\section{Results}

Vascular smooth muscle cells surround the endothelium of blood vessels and regulate vascular tone in response to exogenous and endogenous signals [23]. They also play a key role in vascular repair in response to injury. During this process vascular smooth muscle cells switch from a contractile, quiescent phenotype to a proliferative, synthetic phenotype in which the cells contribute to the repair process [10].

Cellular one carbon metabolism is fueled by dietary folate and methionine (Fig. 1). Increased serum levels of the central metabolite homocysteine have been associated with vascular disease including stroke, coronary heart disease and peripheral arterial disease [38]. This is particularly obvious in the genetic disease of cystathionine B-synthase deficiency which leads to extremely high levels of serum Hcy (up to $100 \mu \mathrm{M}$ compared to a level of $10 \mu \mathrm{M}$ in healthy individuals) and death as a consequence of vascular disease in early life [39]. In addition SNPs in enzymes involved in cellular one carbon metabolism (e.g. MTHFR or methionine synthase) are associated with increased risk of atherosclerosis [40]. These findings link B-vitamin supply with vascular disease. Therefore, we set out to assess whether B-vitamin deficiency affects the switch of vascular smooth muscle cells to a pro-atherogenic phenotype.

\subsection{Differentiation induces a switch in DNA methyl transferase expression in A404 cells}

The differentiation capacity of vascular smooth muscle cells cell culture models is typically characterised by an increase of smooth muscle cell marker gene expression (e.g. MYH11, ACTA2, calponin, SM22/transgelin). To assess the effect of B-vitamin deficiency on the process of smooth muscle cell differentiation we first used the A404 model. This cell line is derived from mouse PC19 embryonal carcinoma cells and can be differentiated towards a smooth muscle cell lineage using retinoic acid. The cells also contain a puromycin marker gene under the control of the MYH11 promoter. Therefore cells which have differentiated can be enriched by puromycin selection [26].

As a first step we differentiated A404 cells as described and monitored the ensuing gene expression changes in smooth muscle cell marker genes ACTA2, SM22, MYH11 and the DNA methyl-transferase genes Dnmt1, 3a and 3b. Retinoic acid treatment strongly increases the expression of the smooth muscle marker genes ACTA2 (smooth muscle $\alpha$-actin), SM22 (transgelin 1) and MYH11 (smooth muscle myosin heavy chain) as measured by quantitative PCR (Fig. 2a). This is supported by Western blot analysis and immune-histochemistry analysis of ACTA2 protein expression (Fig. $\mathbf{2 c}$ and d). At the same time expression of the maintenance DNA methyl transferase 1 (Dnmt1) is increased significantly (9 fold) whereas expression of the de novo methyl transferase $3 \mathrm{~b}$ is significantly decreased (Fig. 2b). As expected, the relative induction of differentiation process is further enhanced by additional treatment of the differentiated cells with puromycin (suppl. Fig. 1). The differentiation process is also accompanied by a drastic (more than 1000-fold) reduction in the expression of the stem cell marker Oct4 (suppl. Fig. 1c). Retinoic acid treatment of A404 cells for 1, 2 and 3 days reveals a gradual increase in smooth muscle marker gene expression over time (suppl. Fig. 1d). 
These data are consistent with published microarray data analysing the retinoic acid/puromycin driven differentiation process (suppl. Fig. 2) [41].

\subsection{Azacytidine treatment promotes smooth muscle cell differentiation in A404 cells}

Differentiation of A404 cells towards a smooth muscle phenotype is associated with Dnmt1 activation. The effect of Dnmt1 activity on the differentiation process was further assessed by treating the A404 cells with different concentrations of azacytidine (an inhibitor of Dnmt1 activity). Azacytidine treatment was initiated 24h before the 3-day retinoic acid treatment.

Azacytidine treatment reduces cell viability at concentrations above $0.1 \mu \mathrm{M}$. But cells remain viable even at $10 \mu \mathrm{M}$, although they divide much more slowly (Fig. 3a). Global DNA methylation in A404 cells as measured by liquid chromatography-mass spectrometry (LCMS) is not significantly affected by the azacytidine treatment (Fig. 3b). Expression of the smooth muscle marker genes $\alpha$-actin and SM22 is affected by azacytidine treatment at higher concentrations. $10 \mu \mathrm{M}$ azacytidine increases expression levels of both marker genes in both, the untreated and the retinoic acid treated cells (Fig. $3 \mathrm{c}$ and d). Lower concentrations of azacytidine also increase expression of $\alpha$-actin and SM22 in retinoic acid treated A404 cells, albeit to a lesser degree (Fig. 3d). Azacytidine has modest effects on the expression of Dnmt1 and Dnmt3b at higher concentrations (Fig. 3c, d, e). Combined treatment of cells with $10 \mu \mathrm{M}$ azacytidine and retinoic acid increase the expression of the stem cell marker Oct4 (Fig. 3e). Treatment of A404 cells with aza-dCTP (rather than azacytidine) shows a similar increase in $\alpha$-actin and SM22 expression in A404 cells in the absence of retinoic acid induction (data not shown). Aza-dCTP is more toxic than azacytidine and the effects of smooth muscle cell marker expression are seen at a lower concentration $(0.5 \mu \mathrm{M}$ aza-dCTP, rather than $10 \mu \mathrm{M}$ azacytidine). These data suggest that although Dnmt1 expression in A404 cells is increased in response to retinoic acid treatment this does not increase global DNA methylation and does not appear to be a prerequisite for differentiation.

\subsection{Folate deficiency promotes $A 404$ smooth muscle cell differentiation}

In order to assess the impact of folate, vitamin B6 and vitamin B12 supply on the phenotypic plasticity of smooth muscle cells, A404 cells were grown in media containing various concentrations of folate, either in the presence of vitamin B6 and B12 or in their absence. Cultured cells are typically grown in medium containing a vast excess of folate $(4000 \mathrm{ng} / \mathrm{ml})$. In order to study the effect of folate and B-vitamin deficiency custom made medium with a maximum folate supplementation of $1000 \mathrm{ng} / \mathrm{ml}$ was used.

Growth of A404 cells is impaired significantly in folate free medium containing vitamins B6 and B12 (Fig. 4a) or devoid of B6 and B12 (Fig. 4b). However, the cells still proliferate in this medium, albeit slowly, due to the presence of between 0.5 to $1 \mathrm{ng} / \mathrm{ml}$ of folate in foetal calf serum (typical concentration $0.6 \mathrm{ng} / \mathrm{ml}$ ). The use of dialysed serum completely blocks cell proliferation in folate free medium (data not shown). Cellular folate stores are severely depleted after an incubation period of 6 days in folate free medium (Fig. 4c). Therefore, homocysteine secretion per cell is significantly elevated in response to folate restriction (homocysteine is an intermediate of cellular one-carbon metabolism which can be regenerated to methionine in the presence of folate; Fig. 1). However, overall

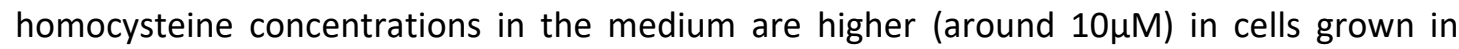
normal medium compared to cells grown in deficient medium (around $1 \mu \mathrm{M}$ ). No significant impact on global DNA methylation can be detected under any of these conditions (Fig. 4e).

The expression of the smooth muscle cell marker genes ACTA2, SM22 and MYH11 is significantly increased in cells exposed to folate and B-vitamin deficiency, even in the absence of retinoic acid (Fig. 4f). The differentiation process induced by retinoic acid treatment is significantly enhanced in folate/B-vitamin deficient cells (Fig. $\mathbf{4 g}$ ). Expression of 
Dnmt genes and their activation by retinoic acid are not significantly affected by folate/Bvitamin deficiency (data not shown). These data suggest that B-vitamin deficiency enhances, rather than inhibits, the differentiation of A404 cells in response to retinoic acid treatment. This conclusion is valid irrespective of the absolute degree of A404 smooth muscle cell differentiation.

\subsection{Folate deficiency promotes vascular smooth muscle cell differentiation in A7r5 cells}

To analyse whether the responses seen in $\mathrm{A} 404$ cells, which represent an early stage of differentiation also apply to a more differentiated vascular smooth muscle cell line, we analysed the bona fide rat vascular smooth muscle cell line A7r5. A7r5 cells respond to extended cultivation at confluence with characteristic morphological changes (including cell elongation, Fig. 5a), and induction of several smooth muscle marker genes like smooth muscle $\alpha$-actin (ACTA2) and smooth muscle myosin heavy chain (MYH11) (Fig. 5b, $\mathbf{c}$ and d). A7r 5 cell grown under conditions of folate deficiency show a reduction in cell proliferation (Fig. 6a and b) even if folate levels are only reduced to the physiological concentration of $10 \mathrm{ng} / \mathrm{ml}$ (Fig. $\mathbf{~} \mathbf{b}$ and $\mathbf{c}$ ). Folate deficiency also leads to a decrease in the concentration of intracellular folate (Fig. 6d), and an increase in secretion of homocysteine per cell (Fig. 6e). The increase of homocysteine secretion is diminished under conditions of additional B6 deficiency in which cell proliferation and, presumably, overall cell metabolism is attenuated (suppl. Fig. 3a). Under conditions of folate deficiency an increase in global DNA methylation (as measured by LC-MS) is detectable (Fig. 6f). In conditions of combined folate and vitamin B6 deficiency this change in DNA global DNA methylation is not observed (Fig. 6f). This change is more pronounced in the presence of vitamin B6 sufficient medium and gradually lost in decreasing medium concentrations of B6 (suppl. Fig. 3b). As in A404 cells, the expression of the smooth muscle cell marker genes MYH11 and SM22 is increased significantly in response to combined folate and B6 deficiency (Fig. 6g). No significant changes can be detected in the expression of ACTA2. A trend towards an increase in gene expression is found for Dnmt3a (Fig. 6h) which was confirmed in later experiments. Dnmt1 expression is unchanged and Dnmt3b expression was undetectable by qPCR in A7r5 cells (using our experimental set-up). A similar set of responses is also seen if folate deficiency is combined with methionine deficiency (suppl. Fig. 4).

\subsection{Microarray analysis detects a shift towards skeletal muscle differentiation in response to} folate deficiency in A7r5 cells

To characterise the gene expression changes in response to folate deficiency more fully, A7r5 cells were grown in medium containing $100 \mathrm{ng} / \mathrm{ml}, 10 \mathrm{ng} / \mathrm{ml}$ or $2.5 \mathrm{ng} / \mathrm{ml}$ of folate and the transcriptome was analysed by an Affymetrix microarray. $100 \mathrm{ng} / \mathrm{ml}$ of folate is representative of supra-physiological folate levels only detected in human serum in response to the consumption of folate supplements. $10 \mathrm{ng} / \mathrm{ml}$ folate represents an average concentration of human serum folate derived from conventional dietary intake. $2.5 \mathrm{ng} / \mathrm{ml}$ folate represents folate levels found in humans with folate deficiency [42].

RNA was harvested from the cells after 7, 14 and 21 days of cultivation and analysed using Affymetrix microarrays. A principal component analysis of the data demonstrates that the main differences in overall gene expression manifest themselves at day 14 and day 21, whereas fewer significant changes are observed at day 7 (Fig. 7). At day 21 there is significant variation between the transcriptome of cells grown at $2.5 \mathrm{ng} / \mathrm{ml}$ and $100 \mathrm{ng} / \mathrm{ml}$, whereas the variation between cells grown at $2.5 \mathrm{ng} / \mathrm{ml}$ and $10 \mathrm{ng} / \mathrm{ml}$ is less pronounced. This is confirmed by Venn diagrams of the gene expression changes (for data with $p<0.01$ and a change bigger than 2-fold; Fig. 8). The top 20 genes regulated by folate availability (increased in $2.5 \mathrm{ng} / \mathrm{ml}$ and increased at $100 \mathrm{ng}$ ) are shown in table 4 . A similar set of gene expression changes is found between cells grown at $2.5 \mathrm{ng} / \mathrm{ml}$ and $10 \mathrm{ng} / \mathrm{ml}$, but the 
amplitude of expression changes is much reduced. E.g. MYH2 expression is increased 11.5fold in cells grown in $2.5 \mathrm{ng} / \mathrm{ml}$ compared to cells grown in $100 \mathrm{ng} / \mathrm{ml}$. The fold change is only 6.5-fold if cell grown in 100 and $10 \mathrm{ng} / \mathrm{ml}$ are compared (Fig. 9).

A pathway analysis was carried out using the TOP-GO, DAVID and Enrichr software suites. TOP-GO analysis ([43] evaluating the Gene Ontology-terms of the regulated genes) identifies pathways associated with cell division and cell proliferation, and cholesterol biosynthesis (GO:0006695) as processes which are significantly regulated by folate availability (table $\mathbf{5}$ ). These data confirm the key role folate plays as a one-carbon donor for DNA synthesis (Fig. 1).

The effect on cholesterol biosynthesis is also consistent with observations that folate supply and lipid metabolism are tightly linked [44-46]. Many of the genes which are significantly downregulated in response to folate deficiency (e.g. insulin induced gene 1 [Insig1], isopentenyl-diphosphate delta isomerase [Idi1], Steaoryl-CoA desaturase 2 [SCD2]) are involved in aspects of lipid and cholesterol biosynthesis [47]. Cholesterol biosynthesis is also the signalling pathway most affected by folate deficiency in a WikiPathways analysis $(p=1.2 \mathrm{x}$ $10^{-10}$ ) in the Enrichr software suite (http://amp.pharm.mssm.edu/Enrichr/). The key role of folate supply for cell proliferation is supported by the identification of mitotic cell cycle as top term in a Reactome 2016 pathway analysis ( $p$ value: $3.2 \times 10^{-21}$ ) and PLK1 (polo-like kinase 1) signalling (a key pathway for mitosis in embryonic cells; $p$-value $2.4 \times 10^{-12}$ ).

A Go-term analysis of genes activated by folate deficiency using the DAVID software (https://david.ncifcrf.gov/) identifies muscle specific genes (GO:0043292 and related GOterms) with the highest enrichment score ( $p$ value $2.8 \times 10^{-7}$ ). This is consistent with the observation that 4 of the 8 genes which are most strongly induced by folate deficiency are skeletal muscle specific genes (table 4). Striated muscle contraction is also the most significant signalling pathway identified by REACTOME analysis in the ENRICHR software suite (suppl. Fig. 5) when a gene list with all genes responsive to folate deficiency $(p<0.01$; fold change $>2$ ) is analysed [48,49]. Cardiac myopathy is the disease network most closely associated with this gene list (suppl. Fig. 5b). Other genes which are activated by folate deficiency include prion protein dublet (Prnd) and inhibitor of DNA binding 1 (Id1). Both of these genes are associated with pro-angiogenic function [50-53]. Consistent with this observation the HIF-1a transcription factor network is the most significant $\mathrm{NCl}-\mathrm{Nature}$ gene network activated in response to folate deficiency (ENRICHR) (suppl. Fig. 5a). Expression of several smooth muscle marker genes (including MYH11, ACTA2, SM22, MYL6L) and other muscle specific marker genes (including the transcription factors serum response factor and myocardin) are increased significantly $(\mathrm{p}<0.001)$, albeit by a small margin (up to around 1.5fold) in response to $2.5 \mathrm{ng} / \mathrm{ml}$ folate treatment (data not shown). This suggests that the higher induction rates seen in deficient medium $(0.6 \mathrm{ng} / \mathrm{ml}, \underline{\text { Fig. }} \mathbf{6 g})$ are elicited by the lower concentration of folate in the medium. Genes encoding enzymes of the cellular one carbon metabolism are only marginally changed by low folate. The biggest significant changes are found for dihydrofolate reductase (DHFR, down-regulated by 1.9 -fold in $2.5 \mathrm{ng} / \mathrm{ml}$ vs $100 \mathrm{ng} / \mathrm{ml}$ of folate, $\mathrm{p}<0.001$ ) and methylene-tetrahydrofolate dehydrogenase (MTHFD2, upregulated by 2 -fold in $2.5 \mathrm{ng} / \mathrm{ml}$ vs $100 \mathrm{ng} / \mathrm{ml}$ of folate, $p<0.001$ ).

Taken together the microarray results confirm that smooth muscle cell markers are increased in response to folate deficiency, but that genes associated with a skeletal muscle phenotype are increased more strongly, together with genes associated with angiogenesis.

\subsection{Folate deficiency induced gene expression changes are not caused by cell cycle arrest}

The expression of the 8 most responsive genes (4 most highly activated in response to high folate and 4 most highly activated in response to low folate) was confirmed using quantitative PCR (data not shown). To assess whether the changes in gene expression were merely due to cell cycle arrest in response to folate deficiency, A7r5 cells were exposed to 2 
other stimuli known to reduce cell proliferation. The cells were grown in medium containing $0.5 \%$ FCS or supplemented with $0.01 \mu \mathrm{M}$ of the iron chelator deferoxamine (DFO). Both treatments significantly reduce cell proliferation (Fig. 10a and b) similar to folate restriction (Fig. 6c). Expression of 7 genes regulated by folate deficiency (4 downregulated by low folate: TXNIP, IDI1, ID1 and INSIG1, 3 upregulated by folate deficiency: MYH2, ACTA1, and PRND) was measured in response to FCS reduction and iron deficiency using quantitative PCR. Expression of IDI1 and ID1 was significantly reduced in response to FCS reduction (as under conditions of folate deficiency) and INSIG1 expression was significantly reduced in response to Fe deficiency (albeit much less than in response to $\mathrm{F}$ deficiency). In the case of TXNIP1, MYH2, ACTA1 and PRND only folate deficiency elicited the characteristic gene expression changes, whereas iron deficiency and low FCS did not. This suggests that most of the gene expression changes observed in the microarray are specific to folate deficiency rather than a reflection of cell cycle arrest. During this analysis it was also found that expression of Dnmt3a was increased in response to folate deficiency (but not iron deficiency or low serum, Fig. 10d) confirming the trend seen in Fig. $\mathbf{6 h}$.

\subsection{Folate deficiency induced gene expression changes are not associated with changes in gene specific DNA methylation}

To assess whether the observed gene expression changes are correlated with gene specific changes in DNA methylation, A7r5 DNA derived from folate deficient and iron deficient cells and cells grown in low serum (0.5\%) were analysed using combined bisulfite restriction analysis (COBRA) and pyrosequencing. Reference points for non-methylated DNA and methylated DNA were established by whole genome amplification and DNA methyltransferase SssI treatment, respectively, and used to establish standard curves for methylation frequency in all experiments (suppl. Fig. 6a).

Whole genome amplified A7r5 DNA only shows $0.2 \%$ of all cytosine residues being methylated when analysed by LC-MS [31] (suppl. Fig. 6d). In contrast in untreated A7r5 DNA $3.1 \%$ of all cytosine residues are methylated. Treatment of naïve A7r5 DNA with Sssl and SAM increases the frequency of methylated cytosine residues to $5 \%$ (suppl. Fig. 6d). In contrast whole genome amplified DNA treated with Sssl only contains $1.2 \%$ of cytosine residues in a methylated state. This suggests that Sssl treatment has limited efficiency on non-methylated genomic DNA (suppl. Fig. 6d). Genomic DNA derived from azacytidine treated A7r5 cells show a progressive global demethylation as assessed by LC-MS (suppl. Fig. 7).

Gene specific methylation of LINE1 and estrogen receptor alpha was measured in genomic DNA derived from folate deficient (and control) A7r5 cells using COBRA (Fig. 11 and suppl. Fig. 8 and 9). Methylation of LINE1 was marginally increased in response to folate deficiency (Fig. 11e and suppl. Fig. 8c and d). It remained unchanged in response to cell cycle arrest inducing treatments of A7r5 cells in 0.5\% FCS and DFO treatment (Fig. 11f). Similarly, methylation of ER $\alpha$ was marginally increased in response to folate deficiency (suppl. Fig. 9d). No significant change in DNA methylation was found for the tumour suppressor gene 14-3-3 sigma (SFN, data not shown) [35]. These marginal DNA methylation changes contrast with a control experiment in which we could find a strong methylation of the CMV promoter in A404 cells compared with HEK293 cells, which correlates with the expression rates of a CMV promoter driven nuclear GFP protein (suppl. Fig. 10). Methylation of a BstUl site in the Prnd gene, which is strongly activated in response to folate deficiency, is significantly decreased in response to folate deficiency, but not in response to reduced serum and iron deficiency (DFO treatment) (Fig. 12).

To get a more comprehensive overview over gene specific methylation in A7r5 cells in response to folate deficiency, iron deficiency and restricted FCS, 7 of the genes strongly regulated by folate deficiency were assessed for gene specific DNA methylation using 
pyrosequencing. CpG islands were identified using the Methyl Primer Express software (Applied Biosystems) and confirmed using the CpG finder software. All 7 genes carry a CpG island in the vicinity of the gene (suppl. Fig. 11). Pyrosequencing assays for these areas were developed using the pyromark software (for Myh2, Acta1, Prnd, Txnip) or purchased as kits from QIAGEN (for Id1, Idi1 and Insig1). The overall methylation rate of the gene sequences is highly variable ranging from $5 \%$ for ID1 to $90 \%$ for PRND. This may reflect the position of the $\mathrm{CpG}$ islands relative to the transcriptional start site (table $\mathbf{3}$ ) which is a known determinant of genome methylation [54]. The results do not show a significant change in gene specific DNA methylation for any of the genes in response to the different treatments (Fig. 13). Control reactions using mixtures of whole genome amplified DNA and SssI treated DNA demonstrate that all sites tested are amenable to the presence and absence of DNA methylation (as shown for the Prnd gene in Fig. 13g). In contrast, a significant (albeit small) decrease in DNA methylation was detected in the Prnd gene in response to azacytidine treatment (suppl. Fig. 12). Taken together with the change in DNA methylation found in the COBRA analysis, this suggests that the Prnd gene may be most susceptible to gene regulation changes by DNA methylation.

\section{Discussion}

We have analysed the effects of folate deficiency on the phenotypic plasticity of vascular smooth muscle cells. Our results demonstrate, firstly, that folate deficiency induces significant changes in global gene expression patterns indicating that the cells adopt a more contractile phenotype. Secondly, the overall expression pattern suggests a transdifferentiation towards a skeletal muscle phenotype. Thirdly, folate deficiency mediated alterations of cellular one-carbon metabolism do not induce DNA methylation changes in CpG islands associated with folate responsive genes.

Folate deficiency is associated with several disease phenotypes. The most important of these is neural tube defects $[55,56]$ which has led to the introduction of fortification of flour with folic acid in some countries [57]. The caveat to this approach is the promotion of cell proliferation which can have a small but measurable cancer promoting effect [58]. This is not surprising as many cancer drugs (e.g. methotrexate; see Fig. 1) act as anti-folates interfering with folate-supported DNA synthesis. Another well characterised disease outcome of folate deficiency is colon cancer which has been documented in animal studies and epidemiological observations in human populations [59]. Finally, folate deficiency (and one of its physiological outcomes, increased serum homocysteine levels) is associated with an increased risk of cardiovascular disease $[60,61]$. The mechanisms by which B-vitamin deficiency impacts on CVD risk, however, are unclear.

Numerous studies have investigated potential direct effects of homocysteine on vascular health. Several mechanistic explanations have been put forward including a promotion of inflammation, an increased proliferation of VSMC in the neointima, a toxic effect on the vascular endothelium, and cell signalling alterations [62]. Some studies in model systems seemed to support a mechanistic role for homocysteine in cardiovascular disease progression by promoting VSCM proliferation [11]. However other studies (including our own) failed to establish a conclusive link between serum homocysteine concentrations and vascular disease progression $[7,8,13]$. Specifically, our data demonstrate that plaque formation is not correlated with serum homocysteine levels. Under conditions of combined folate and B-vitamin deficiency serum homocysteine levels of around $50 \mu \mathrm{M}$ were detected, whereas folate deficiency alone only increased serum homocysteine to $15 \mu \mathrm{M}$. In contrast, significant increases in plaque formation were detected in folate deficient, but not in 
combined folate/B-vitamin deficient mice [8]. This is supported by another rodent model system, which specifically demonstrated that provision of high methionine seems to be the predominant driver of vascular disease and not high homocysteine levels [13]. These data argue against a direct link of serum homocysteine levels with the extent of vascular plaque formation.

Moreover, the finding that B-vitamin supplementation in cardiovascular patients reduces serum homocysteine, but appears to be of no clinical benefit has led to the suggestion that homocysteine may be a marker for B-vitamin deficiency, rather than an active agent in vascular disease progression $[15,16]$. These findings may be explained in two ways. Firstly, homocysteine may have no further effect on disease progression, once overt cardiovascular disease is present. Alternatively, homocysteine lowering may only be clinically effective in the small group of patients which suffer from severe hyperhomocysteinemia (i.e. serum homocysteine levels of higher than $100 \mu \mathrm{M}$; incidentally this is the concentration which is typically used in rodent and in vitro models of hyperhomocysteinemia) [62]. Therefore, other mechanistic links between B-vitamin deficiency and cardiovascular disease risk are being considered.

Hiltunen et al. observed a reduction in global DNA methylation of vascular smooth muscle cells in association with cardiovascular disease in a mouse/rat model $[25,63]$. This led to the hypothesis that B-vitamin deficiency may exert its effect on cardiovascular disease via epigenetic mechanism like DNA methylation or histone methylation. A potential link between folate supply, DNA methylation, and gene expression has been demonstrated e.g. for the agouti mouse model and related "metastable" alleles [64]. We have therefore studied the effects of folate, vitamins B6 and B12, and methionine deficiency in two complementary cell culture models representing early and late differentiation stages of vascular smooth muscle cells.

Our results allow two major conclusions. Firstly, folate deficiency does not prevent the establishment or maintenance of a differentiated vascular smooth muscle phenotype. In fact, the expression of smooth muscle cell marker genes is increased in response to folate deficiency in both, A404 and A7r5 cells. However, the microarray analysis of A7r5 cells suggests a shift of overall gene expression towards a skeletal muscle phenotype. Transdifferentiation on A7r5 cells into skeletal muscle has been observed before as a spontaneous outcome of cultivation but was only characterised by expression of two skeletal muscle proteins [65]. Our results suggest that an exogenous stressor like folate deficiency can promote this process. In addition, several genes involved in tissue repair are also activated in response to folate deficiency, while genes involved in cholesterol and lipid metabolism are downregulated. This is also reflected for the overall transcriptome by pathway analyses. The close link between B-vitamin/one carbon metabolism and lipid metabolism is well characterised and supports the findings of other researchers [44-46]. Trans-differentiation of VSMC in vivo has been documented $[66,67]$ but is controversial $[68,69]$. The most relevant trans-differentiation processes observed in vivo appear to be towards an osteogenic and macrophage (rather than a skeletal muscle) lineage [66,67].

We have previously studied the effects of folate and vitamin B6 and B12 deficiency in the arterial tissue of folate deficient apoE-/- mice using proteomics $[8,70]$. Some of the changes seen in that analysis are also reflected in the A7r5 cells. E.g. the transferrin receptor, the electron-transfer flavoprotein, lactate dehydrogenase, glutathione-Stransferase mu1, several fibrinogen polypeptides are all significantly upregulated in conditions of folate deficiency in both analysis systems. The fact that the major changes seen in A7r 5 cells are not seen in the whole aorta is presumably due to the different sensitivities of the two analyses (microarray vs proteomics, the latter only revealing changes in highly 
expressed proteins) and the modest contribution of smooth muscle cells to the overall tissue composition of a complete aorta.

The second conclusion from the data presented is that changes in gene expression are not correlated with significant changes in DNA methylation of $\mathrm{CpG}$ islands associated with genes regulated by folate supply. This is in accordance with recent findings by McKay et al. who found that gene expression and DNA methylation changes in the liver of folate deficient mice were not correlated for most genes [71]. In addition, Wang et al. investigated the role of DNA methylation in a model of neural tube defects, and found that the expression of very few genes was changed as a consequence of DNA methylation changes [72]. In contrast, Leclerc et al. found small but significant increases in the methylation of CpG islands associated with tumour suppressor genes in colon tumours induced by folate deficiency in C57B/6 mice [73]. However, even in that case the DNA methylation changes detected (by pyrosequencing) were in the range of a few percent; similar to the amplitude of changes we detect in some of the assays, especially for the Prnd gene. The available data suggest that while the methylation status of some genes is sensitive to environmental changes (like folate supply) for most genes no significant methylation changes are found. In order to conclusively assess the specific effect of environmental changes on DNA methylation a whole genome sequencing of bisulfite converted DNA would be necessary.

Recent technological advances have enabled the site directed modification of DNA methylation using fusion proteins of Cas9 with Dnmt3a or Tet1 [74-76] in which the methylating or demethylating activities are targeted to sites specified by guide RNAs interacting with Cas9. While these experiments clearly demonstrate a link between the methylation of target genes with their expression, it is possible that these effects only apply to a subset of genes. Our data also show profound impacts of DNA methylation on the expression of a CMV-GFP transgene stably inserted in HEK293 cells and A404 cells. Taken together these data suggest that a simple correlation between gene specific DNA methylation changes resulting in altered gene expression, as is the case for metastable alleles, is not generally applicable. Alternatively, DNA methylation changes in one genomic location may have long range effects on chromosome architecture resulting in changes of expression of distant genes with consequent changes in biological phenotypes.

The results in this study also raise the question as to how important folate supply is for DNA methylation. It is probable that DNA methylation of genes is mainly malleable during early stages of development (as reflected in the A404 cells). Effects of early life nutrition on cardiovascular disease risk have indeed been demonstrated [77]. We only detected small changes in global or gene specific DNA methylation in both vascular smooth muscle cell lines in response to folate deficiency, reflecting our findings in mice [8]. Human studies have demonstrated that folate and B-vitamin supply in utero can have differing effects on the methylation of different imprinted genes [78,79]. In addition, direct analysis of gene expression correlated with these methylation changes is restricted as very few tissues which are accessible for such studies in humans (mainly lymphocytes).

DNA methylation enzymes compete for methyl groups with other cellular processes like DNA synthesis [80]. In tumour cells an increased requirement for de novo nucleotide synthesis can therefore decrease overall levels of DNA methylation. However, even a dramatic increase in the DNA de novo synthesis rate of $36 \%$ (e.g. in tumour cells) only reduces the DNA methylation rate by $0.5 \%$ [81] suggesting that DNA methylation is not particularly responsive to one carbon unit supply. In addition, histone methylation, another mechanism of epigenetic gene control, may also provide a target for gene regulatory effects of folate deficiency. It has been suggested that THF (derived from dietary folate) is required to protect lysine demethylase enzymes from the formaldehyde generated as a consequence of histone demethylation [82]. Folate deficiency may therefore impair histone 
demethylation thereby impacting on gene regulation. B-vitamin deficiency may also affect cardiovascular disease risk indirectly via other processes, including DNA repair, micro RNA stress responses, inflammation and energy sensors, like mTOR [83-86] either with or without epigenetic alterations.

\section{Conclusions}

Taken together the data shown in here demonstrate that folate deficiency promotes a contractile phenotype in vascular smooth muscle cells, combined with a transdifferentiation towards a skeletal muscle gene expression profile. These expression changes are not accompanied by altered DNA methylation of the regulated genes. The data also clearly show that a simple correlation of gene specific DNA methylation changes and altered gene expression, as is the case for metastable alleles, is not generally applicable.

\section{Acknowledgements}

Microarray data shown in this manuscript have been deposited at NCBI via the Gene Expression Omnibus webpage under number: GSE125502. This work was funded by The Scottish Government Rural and Environment Science and Analytical Services Division (RESAS). The funder had no role in the design of the study, the analysis and interpretation of the data, or the publication process. The authors would like to thank Drs Bill Rees and Perry Barrett for helpful discussions throughout the project and on the manuscript. There are no competing interests to declare.

\section{Authors' contributions}

Andreas Kolb designed and supervised the study, carried out experimental work, and wrote the manuscript, Linda Petrie and Lynn Pirie carried out experimental work, Claus Mayer analysed the microarray data, Susan Duthie co-designed and co-supervised the study and cowrote the manuscript.

\section{References}

1 Ntaios, G., Savopoulos, C., Grekas, D. and Hatzitolios, A. (2009) The controversial role of B-vitamins in cardiovascular risk: An update. Arch. Cardiovasc. Dis., Elsevier Masson 102, 847-854.

2 Zaina, S., Lindholm, M. W. and Lund, G. (2005) Nutrition and Aberrant DNA Methylation Patterns in Atherosclerosis: More than Just Hyperhomocysteinemia? J. Nutr. 135, 5-8.

3 Lund, G., Andersson, L., Lauria, M., Lindholm, M., Fraga, M. F., Villar-Garea, A., Ballestar, E., Esteller, M. and Zaina, S. (2004) DNA Methylation Polymorphisms Precede Any Histological Sign of Atherosclerosis in Mice Lacking Apolipoprotein E. J. Biol. Chem. 279, 29147-29154.

4 Ghandour, H., Chen, Z., Selhub, J. and Rozen, R. (2004) Mice Deficient in Methylenetetrahydrofolate Reductase Exhibit Tissue-Specific Distribution of Folates. J. Nutr. 134, 2975-2978.

5 Chen, Z., Karaplis, A. C., Ackerman, S. L., Pogribny, I. P., Melnyk, S., Lussier-Cacan, S., 
Chen, M. F., Pai, A., John, S. W. M., Smith, R. S., et al. (2001) Mice deficient in methylenetetrahydrofolate reductase exhibit hyperhomocysteinemia and decreased methylation capacity, with neuropathology and aortic lipid deposition. Hum. Mol. Genet. 10, 433-443.

6 Thambyrajah, J. and Townend, J. . (2000) Homocysteine and atherothrombosismechanisms for injury. Eur. Heart J., Narnia 21, 967-974.

7 Hofmann, M. A., Lalla, E., Lu, Y., Gleason, M. R., Wolf, B. M., Tanji, N., Ferran Jr., L. J., Kohl, B., Rao, V., Kisiel, W., et al. (2001) Hyperhomocysteinemia enhances vascular inflammation and accelerates atherosclerosis in a murine model. J. Clin. Invest. 107, 675-683.

8 McNeil, C. J., Beattie, J. H., Gordon, M.-J., Pirie, L. P. and Duthie, S. J. (2011) Differential effects of nutritional folic acid deficiency and moderate hyperhomocysteinemia on aortic plaque formation and genome-wide DNA methylation in vascular tissue from ApoE-/- mice. Clin. Epigenetics 2, 361-8. Zhou, J., Moller, J., Danielsen, C. C., Bentzon, J., Ravn, H. B., Austin, R. C. and Falk, E. (2001) Dietary Supplementation With Methionine and Homocysteine Promotes Early Atherosclerosis but Not Plaque Rupture in ApoE-Deficient Mice. Arter. Thromb Vasc Biol 21, 1470-1476.

10 Gomez, D. and Owens, G. K. (2012) Smooth muscle cell phenotypic switching in atherosclerosis. Cardiovasc. Res., Oxford University Press 95, 156-64.

11 Bloor, J., Shukla, N., Smith, F. C. T., Angelini, G. D. and Jeremy, J. Y. (2010) Folic acid administration reduces neointimal thickening, augments neo-vasa vasorum formation and reduces oxidative stress in saphenous vein grafts from pigs used as a model of diabetes. Diabetologia, Europe PMC Funders 53, 980-8. Qureshi, I., Chen, H., Brown, A. T., Fitzgerald, R., Zhang, X., Breckenridge, J., Kazi, R., Crocker, A. J., Stühlingexsr, M. C., Lin, K., et al. (2005) Homocysteine-induced vascular dysregulation is mediated by the NMDA receptor. Vasc. Med., Sage PublicationsSage CA: Thousand Oaks, CA 10, 215-223.

13 Troen, A. M., Lutgens, E., Smith, D. E., Rosenberg, I. H. and Selhub, J. (2003) The atherogenic effect of excess methionine intake. Proc Natl Acad Sci U S A 100, 1508915094.

14 Zhou, J., Moller, J., Ritskes-Hoitinga, M., Larsen, M. L., Austin, R. C. and Falk, E. (2003) Effects of vitamin supplementation and hyperhomocysteinemia on atherosclerosis in apoE-deficient mice. Atherosclerosis 168, 255-262.

15 Ebbing, M., Bleie, $\varnothing$., Ueland, P. M., Nordrehaug, J. E., Nilsen, D. W., Vollset, S. E., Refsum, H., Ringdal Pedersen, E. K., Nygård, O., Bleie, O., et al. (2008) Mortality and cardiovascular events in patients treated with homocysteine-lowering $B$ vitamins after coronary angiography: a randomized controlled trial. Jama 300, 795-804. Martí-Carvajal, A. J., Solà, I., Lathyris, D. and Dayer, M. (2017) Homocysteine-lowering interventions for preventing cardiovascular events. Cochrane Database Syst. Rev., John Wiley and Sons, Inc. and the Cochrane Library 8, CD006612. Hiltunen, M. O. and Yla-Herttuala, S. (2003) DNA Methylation, Smooth Muscle Cells, and Atherogenesis. Arter. Thromb Vasc Biol 23, 1750-1753.

18 Waterland, R. A. (2003) Do maternal methyl supplements in mice affect DNA methylation of offspring? J Nutr 133, 238; author reply 239.

19 Waterland, R. A. and Jirtle, R. L. (2004) Early nutrition, epigenetic changes at transposons and imprinted genes, and enhanced susceptibility to adult chronic diseases. Nutrition 20,63-68.

20 Carter, M., Ulrich, S., Oofuji, Y., Williams, D. A. and Ross, M. E. (1999) Crooked tail (Cd) models human folate-responsive neural tube defects. Hum. Mol. Genet. 8, 21992204. 
21 Gomez, D., Swiatlowska, P. and Owens, G. K. (2015) Epigenetic Control of Smooth Muscle Cell Identity and Lineage Memory. Arterioscler. Thromb. Vasc. Biol. 35, 250816.

22 Ingrosso, D., Cimmino, A., Perna, A. F., Masella, L., De Santo, N. G., De Bonis, M. L., Vacca, M., D'Esposito, M., D'Urso, M., Galletti, P., et al. (2003) Folate treatment and unbalanced methylation and changes of allelic expression induced by hyperhomocysteinaemia in patients with uraemia. Lancet 361, 1693-1699.

23 Brozovich, F. V, Nicholson, C. J., Degen, C. V, Gao, Y. Z., Aggarwal, M. and Morgan, K. G. (2016) Mechanisms of Vascular Smooth Muscle Contraction and the Basis for Pharmacologic Treatment of Smooth Muscle Disorders. Pharmacol. Rev., American Society for Pharmacology and Experimental Therapeutics 68, 476-532. Liu, R., Leslie, K. L. and Martin, K. A. (2015) Epigenetic regulation of smooth muscle cell plasticity. Biochim. Biophys. Acta 1849, 448-53. Hiltunen, M. O., Turunen, M. P., Hakkinen, T. P., Rutanen, J., Hedman, M., Makinen, K., Turunen, A. M., Aalto-Setala, K. and Yla-Herttuala, S. (2002) DNA hypomethylation and methyltransferase expression in atherosclerotic lesions. Vasc Med 7, 5-11. Manabe, I. and Owens, G. K. (2001) Recruitment of Serum Response Factor and Hyperacetylation of Histones at Smooth Muscle-Specific Regulatory Regions During Differentiation of a Novel P19-Derived In Vitro Smooth Muscle Differentiation System. Circ Res 88, 1127-1134.

27 Valerio, A., Baldo, G. and Tessari, P. (2005) A rapid method to determine plasma homocysteine concentration and enrichment by gas chromatography/mass spectrometry. Rapid Commun. Mass Spectrom. 19, 561-567.

28 Ihaka, R. and Gentleman, R. (1996) R: A Language for Data Analysis and Graphics. J. Comput. Graph. Stat. 5, 299-314.

29 Gentleman, R. C., Carey, V. J., Bates, D. M., Bolstad, B., Dettling, M., Dudoit, S., Ellis, B., Gautier, L., Ge, Y., Gentry, J., et al. (2004) Bioconductor: open software development for computational biology and bioinformatics. Genome Biol, BioMed Central 5, R80.

30 Ritchie, M. E., Phipson, B., Wu, D., Hu, Y., Law, C. W., Shi, W. and Smyth, G. K. (2015) limma powers differential expression analyses for RNA-sequencing and microarray studies. Nucleic Acids Res., Oxford University Press 43, e47.

31 Friso, S., Choi, S. W., Dolnikowski, G. G. and Selhub, J. (2002) A method to assess genomic DNA methylation using high-performance liquid chromatography/electrospray ionization mass spectrometry. Anal Chem 74, 45264531.

32 Xiong, Z. and Laird, P. W. (1997) COBRA: a sensitive and quantitative DNA methylation assay. Nucl. Acids Res. 25, 2532-2534.

33 Pogribny, I. P., Ross, S. A., Wise, C., Pogribna, M., Jones, E. A., Tryndyak, V. P., James, S. J., Dragan, Y. P. and Poirier, L. A. (2006) Irreversible global DNA hypomethylation as a key step in hepatocarcinogenesis induced by dietary methyl deficiency. Mutat. Res. Mol. Mech. Mutagen. 593, 80.

34 Monje, L., Varayoud, J., Luque, E. H. and Ramos, J. G. (2007) Neonatal exposure to bisphenol A modifies the abundance of estrogen receptor \{alpha\} transcripts with alternative 5'-untranslated regions in the female rat preoptic area. J Endocrinol 194, 201-212.

35 Chen, T., Mally, A., Ozden, S. and Chipman, J. K. (2010) Low Doses of the Carcinogen Furan Alter Cell Cycle and Apoptosis Gene Expression in Rat Liver Independent of DNA Methylation. Environ. Health Perspect. 118, 1597-1602.

36 Kolb, A. F., Maile, J., Heister, A. and Siddell, S. G. (1996) Characterization of functional domains in the human coronavirus HCV 229E receptor. J. Gen. Virol. 77 ( Pt 10, 2515- 
21.

37 Szymanowska, M., Hendry, K. A. ., Robinson, C. and Kolb, A. F. (2009) EMMPRIN (basigin/CD147) expression is not correlated with MMP activity during adult mouse mammary gland development. J. Cell. Biochem. 106, 52-62. Homocysteine Studies Collaboration and Homocysteine Studies, C. (2002) Homocysteine and Risk of Ischemic Heart Disease and Stroke: A Meta-analysis. Jama 288, 2015-2022.

39 Dayal, S., Bottiglieri, T., Arning, E., Maeda, N., Malinow, M. R., Sigmund, C. D., Heistad, D. D., Faraci, F. M. and Lentz, S. R. (2001) Endothelial dysfunction and elevation of S-adenosylhomocysteine in cystathionine beta-synthase-deficient mice. Circ Res 88, 1203-1209.

40 Liew, S.-C. and Gupta, E. Das. (2015) Methylenetetrahydrofolate reductase (MTHFR) C677T polymorphism: Epidemiology, metabolism and the associated diseases. Eur. J. Med. Genet., Elsevier Masson 58, 1-10.

41 Spin, J. M., Quertermous, T. and Tsao, P. S. (2010) Chromatin remodeling pathways in smooth muscle cell differentiation, and evidence for an integral role for $\mathrm{p} 300$. PLoS One, Public Library of Science 5, e14301.

42 De Bruyn, E., Gulbis, B. and Cotton, F. (2013) Serum and red blood cell folate testing for folate deficiency: new features? Eur. J. Haematol., Wiley/Blackwell (10.1111) 92, 354-359.

43 Alexa, A., Rahnenfuhrer, J. and Lengauer, T. (2006) Improved scoring of functional groups from gene expression data by decorrelating $\mathrm{GO}$ graph structure. Bioinformatics, Oxford University Press 22, 1600-1607.

44 McNeil, C. J., Hay, S. M., Rucklidge, G. J., Reid, M., Duncan, G., Maloney, C. A. and Rees, W. D. (2008) Disruption of lipid metabolism in the liver of the pregnant rat fed folate-deficient and methyl donor-deficient diets. Br. J. Nutr. 99, 262-71.

45 Adaikalakoteswari, A., Finer, S., Voyias, P. D., McCarthy, C. M., Vatish, M., Moore, J., Smart-Halajko, M., Bawazeer, N., Al-Daghri, N. M., McTernan, P. G., et al. (2015) Vitamin B12 insufficiency induces cholesterol biosynthesis by limiting sadenosylmethionine and modulating the methylation of SREBF1 and LDLR genes. Clin. Epigenetics, BioMed Central 7, 14.

46 Li, Y., Zhang, X., Sun, Y., Feng, Q., Li, G., Wang, M., Cui, X., Kang, L. and Jiang, Y. (2013) Folate Deficiency during Early-Mid Pregnancy Affects the Skeletal Muscle Transcriptome of Piglets from a Reciprocal Cross. PLoS One (Wu, Q., ed.) 8, e82616.

47 McFarlane, M. R., Liang, G. and Engelking, L. J. (2014) Insig proteins mediate feedback inhibition of cholesterol synthesis in the intestine. J Biol Chem, American Society for Biochemistry and Molecular Biology 289.

48 Chen, E. Y., Tan, C. M., Kou, Y., Duan, Q., Wang, Z., Meirelles, G. V., Clark, N. R. and Ma'ayan, A. (2013) Enrichr: interactive and collaborative HTML5 gene list enrichment analysis tool. BMC Bioinformatics, BioMed Central 14, 128.

49 Kuleshov, M. V, Jones, M. R., Rouillard, A. D., Fernandez, N. F., Duan, Q., Wang, Z., Koplev, S., Jenkins, S. L., Jagodnik, K. M., Lachmann, A., et al. (2016) Enrichr: a comprehensive gene set enrichment analysis web server 2016 update. Nucleic Acids Res., Oxford University Press 44, W90-7.

50 Al-Hilal, T. A., Chung, S. W., Choi, J. U., Alam, F., Park, J., Kim, S. W., Kim, S. Y., Ahsan, F., Kim, I.-S. and Byun, Y. (2016) Targeting prion-like protein doppel selectively suppresses tumor angiogenesis. J. Clin. Invest., American Society for Clinical Investigation 126, 1251-66.

51 Perry, S. S., Zhao, Y., Nie, L., Cochrane, S. W., Huang, Z. and Sun, X.-H. (2007) Id1, but not Id3, directs long-term repopulating hematopoietic stem-cell maintenance. Blood 110, 2351-2360. 
Wen, D., Zou, Y.-F., Gao, Y.-H., Zhao, Q., Xie, Y.-Y., Shen, P.-Y., Xu, Y.-W., Xu, J., Chen, Y.-X., Feng, X.-B., et al. (2016) Inhibitor of DNA Binding 1 Is Induced during Kidney Ischemia-Reperfusion and Is Critical for the Induction of Hypoxia-Inducible Factor- $1 \alpha$. Biomed Res. Int., Hindawi 2016, 1-10.

53 Hung, Y.-H., Chang, S.-H., Huang, C.-T., Yin, J.-H., Hwang, C.-S., Yang, L.-Y. and Yang, D.-I. (2016) Inhibitor of Differentiation-1 and Hypoxia-Inducible Factor-1 Mediate Sonic Hedgehog Induction by Amyloid Beta-Peptide in Rat Cortical Neurons. Mol. Neurobiol. 53, 793-809.

54 Guo, H., Zhu, P., Yan, L., Li, R., Hu, B., Lian, Y., Yan, J., Ren, X., Lin, S., Li, J., et al. (2014) The DNA methylation landscape of human early embryos. Nature, Nature Publishing Group 511, 606-610.

55 Czeizel, A. E. (1995) Nutritional supplementation and prevention of congenital abnormalities. Curr Opin Obs. Gynecol 7, 88-94. Pitkin, R. M. (2007) Folate and neural tube defects. Am J Clin Nutr 85, 285S - 288. Jacques, P. F., Selhub, J., Bostom, A. G., Wilson, P. W. F. and Rosenberg, I. H. (1999) The Effect of Folic Acid Fortification on Plasma Folate and Total Homocysteine Concentrations. N. Engl. J. Med. 340, 1449-1454. Mason, J. B., Dickstein, A., Jacques, P. F., Haggarty, P., Selhub, J., Dallal, G. and Rosenberg, I. H. (2007) A Temporal Association between Folic Acid Fortification and an Increase in Colorectal Cancer Rates May Be Illuminating Important Biological Principles: A Hypothesis. Cancer Epidemiol. Biomarkers Prev. 16, 1325-1329.

59 Mathers, J. (2009) Folate intake and bowel cancer risk. Genes Nutr. 4, 173.

60 McNulty, H., Pentieva, K., Hoey, L. and Ward, M. (2008) Homocysteine, B-vitamins and CVD. Proc Nutr Soc 67, 232-237.

61 Ward, M., McNulty, H., McPartlin, J., Strain, J. J., Weir, D. G. and Scott, J. M. (1997) Plasma homocysteine, a risk factor for cardiovascular disease, is lowered by physiological doses of folic acid. Qjm 90, 519-524. Antoniades, C., Antonopoulos, A. S., Tousoulis, D., Marinou, K. and Stefanadis, C. (2009) Homocysteine and coronary atherosclerosis: from folate fortification to the recent clinical trials. Eur Hear. J 30, 6-15. Hiltunen, M. O., Tuomisto, T. T., Niemi, M., Brasen, J. H., Rissanen, T. T., Toronen, P., Vajanto, I. and Yla-Herttuala, S. (2002) Changes in gene expression in atherosclerotic plaques analyzed using DNA array. Atherosclerosis 165, 23-32. Waterland, R. A. and Michels, K. B. (2007) Epigenetic Epidemiology of the Developmental Origins Hypothesis. Annu. Rev. Nutr. 27, 363-388. Graves, D. C., Yablonka-Reuveni, Z. and Yablonka-Reuveni, Z. (2000) Vascular Smooth Muscle Cells Spontaneously Adopt a Skeletal Muscle Phenotype: A Unique Myf5/MyoD+ Myogenic Program. J. Histochem. Cytochem. 48, 1173-1193. Goettsch, C., Rauner, M., Pacyna, N., Hempel, U., Bornstein, S. R. and Hofbauer, L. C. (2011) miR-125b Regulates Calcification of Vascular Smooth Muscle Cells. Am. J. Pathol., Elsevier 179, 1594-1600. and Feil, R. (2014) Transdifferentiation of Vascular Smooth Muscle Cells to Macrophage-Like Cells During Atherogenesis. Circ. Res. 115, 662-667. Swirski, F. K. and Nahrendorf, M. (2014) Do vascular smooth muscle cells differentiate to macrophages in atherosclerotic lesions? Circ. Res., NIH Public Access 115, 605-6.

69 Bentzon, J. F. and Majesky, M. W. (2018) Lineage tracking of origin and fate of smooth muscle cells in atherosclerosis. Cardiovasc. Res., Oxford University Press 114, 492-500. 
alters the expression of key proteins associated with vascular smooth muscle cell proliferation and migration in the aorta of atherosclerotic apolipoprotein $\mathrm{E}$ null mice. Genes Nutr. 10, 446.

71 McKay, J. A., Adriaens, M., Evelo, C. T., Ford, D. and Mathers, J. C. (2016) Gene promoter DNA methylation patterns have a limited role in orchestrating transcriptional changes in the fetal liver in response to maternal folate depletion during pregnancy. Mol. Nutr. Food Res., Wiley-Blackwell 60, 2031-42.

72 Wang, X., Guan, Z., Chen, Y., Dong, Y., Niu, Y., Wang, J., Zhang, T. and Niu, B. (2015) Genomic DNA hypomethylation is associated with neural tube defects induced by methotrexate inhibition of folate metabolism. PLoS One, Public Library of Science 10, e0121869.

73 Leclerc, D., Cao, Y., Deng, L., Mikael, L. G., Wu, Q. and Rozen, R. (2013) Differential gene expression and methylation in the retinoid/PPARA pathway and of tumor suppressors may modify intestinal tumorigenesis induced by low folate in mice. Mol. Nutr. Food Res., Wiley-Blackwell 57, 686-697.

74 Liu, X. S., Wu, H., Ji, X., Stelzer, Y., Wu, X., Czauderna, S., Shu, J., Dadon, D., Young, R. A. and Jaenisch, R. (2016) Editing DNA Methylation in the Mammalian Genome. Cell, Elsevier 167, 233-247.e17.

75 Vojta, A., Dobrinić, P., Tadić, V., Bočkor, L., Korać, P., Julg, B., Klasić, M. and Zoldoš, V. (2016) Repurposing the CRISPR-Cas9 system for targeted DNA methylation. Nucleic Acids Res., Oxford University Press 44, 5615-28.

76 Lei, Y., Zhang, X., Su, J., Jeong, M., Gundry, M. C., Huang, Y.-H., Zhou, Y., Li, W. and Goodell, M. A. (2017) Targeted DNA methylation in vivo using an engineered dCas9MQ1 fusion protein. Nat. Commun., Nature Publishing Group 8, 16026.

77 Guardamagna, O., Abello, F., Cagliero, P. and Lughetti, L. (2012) Impact of nutrition since early life on cardiovascular prevention. Ital. J. Pediatr., BioMed Central 38, 73.

78 Haggarty, P., Hoad, G., Campbell, D. M., Horgan, G. W., Piyathilake, C. and McNeill, G. (2013) Folate in pregnancy and imprinted gene and repeat element methylation in the offspring. Am. J. Clin. Nutr., Oxford University Press 97, 94-99. Dominguez-Salas, P., Moore, S. E., Baker, M. S., Bergen, A. W., Cox, S. E., Dyer, R. A., Fulford, A. J., Guan, Y., Laritsky, E., Silver, M. J., et al. (2014) Maternal nutrition at conception modulates DNA methylation of human metastable epialleles. Nat Commun, Nature Publishing Group, a division of Macmillan Publishers Limited. All Rights Reserved. 5.

80 Stover, P. J. (2009) One-carbon metabolism-genome interactions in folate-associated pathologies. J. Nutr., American Society for Nutrition 139, 2402-5.

81 Cao, S., Zhu, X., Zhang, C., Qian, H., Schuttler, H.-B., Gong, J. and Xu, Y. (2017) Competition between DNA Methylation, Nucleotide Synthesis, and Antioxidation in Cancer versus Normal Tissues. Cancer Res., American Association for Cancer Research 77, 4185-4195.

82 Garcia, B. A., Luka, Z., Loukachevitch, L. V, Bhanu, N. V and Wagner, C. (2016) Folate deficiency affects histone methylation. Med. Hypotheses, NIH Public Access 88, 63-7.

83 Duthie, S. (2010) Folate and cancer: how DNA damage, repair and methylation impact on colon carcinogenesis. J. Inherit. Metab. Dis.

84 Marsit, C. J., Eddy, K. and Kelsey, K. T. (2006) MicroRNA Responses to Cellular Stress. Cancer Res 66, 10843-10848.

85 Silva, E., Rosario, F. J., Powell, T. L. and Jansson, T. (2017) Mechanistic Target of Rapamycin Is a Novel Molecular Mechanism Linking Folate Availability and Cell Function. J. Nutr., American Society for Nutrition 147, 1237-1242. Kolb, A. F. and Petrie, L. (2013) Folate deficiency enhances the inflammatory response of macrophages. Mol. Immunol. 54, 164-72. 
B-vitamin mediated gene regulation in vascular smooth muscle cells 


\section{Figure legends:}

Table 1: Oligonucleotides used for quantitative PCR. Primer sequences, annealing temperatures and expected product sizes are given.

Table 2: Oligonucleotides used for COBRA analyses.

Table 3: Oligonucleotides used for pyrosequencing analyses and gene sequences analysed.

Table 4: Top 20 gene expression changes in response to folate deficiency. Fold change of gene expression between A7r5 cells grown in in folate sufficient $(100 \mathrm{ng} / \mathrm{ml})$ and folate deficient $(2.5 \mathrm{ng} / \mathrm{ml})$ medium

Table 5: TOP-GO pathway analysis of transcriptome changes in response to folate deficiency. elimKS here gives the p-values from topGO specific Kolmogorov-Smirnov Test with elimination of genes of significant GO-terms in parent terms.

Figure 1: Schematic representation of cellular one carbon metabolism. Relevant enzymes are shown: methylene tetrahydrofolate reductase (MTHFR), methionine synthase (MS), cystathionine-B-synthase (CBS), di-hydrofolate reductase (DHFR), betaine-homocysteine Smethyltransferase (BHMT). Enyzmes dependent on B-vitamins are indicated [B6], [B12]. Dietary folate is a precursor for both, DNA synthesis and DNA methylation. Methotrexate is a classic example of an "anti-folate" used in cancer therapy. It is a highly effective competitive inhibitor of DHFR.

Figure 2: Analysis of smooth muscle marker and Dnmt gene expression in A404 cells. A404 cells were treated with $1 \mu \mathrm{M}$ all-trans retinoic acid (dissolved in DMSO; stock solution $1 \mathrm{mM}$ ) or equivalent concentration of solvent for 3 days. RNA was isolated, reverse transcribed and analysed by quantitative real time PCR. Expression of the smooth muscle $\alpha$-actin (ACTA2), SM22, myosin heavy chain (MYH11), Dnmt1, Dnmt3a and Dnmt3b genes was measured and correlated with expression of the reference gene GAPDH. Panel A: Fold induction of the smooth muscle cell marker genes ACTA2, SM22 and MYH11 in A404 cells treated with retinoic acid supplemented medium relative to control medium. Panel B: Fold induction of the DNA methyl-transferase genes Dnmt1, 3a and 3b in A404 cells treated with retinoic acid supplemented medium relative to control medium. Panel C: Western blot analysis of cytoplasmic extracts from A404 cells treated with retinoic acid supplemented medium ([+]RA) and control medium ([-]RA). Smooth muscle $\alpha$-actin (ACTA2) and $\beta$-actin (ACTB) were detected using specific monoclonal antibodies. Statistical analysis was done by ANOVA $(n=4)$. $\mathrm{p}<0.05:{ }^{*}, \mathrm{p}<0.01:{ }^{* *}, \mathrm{p}<0,001:{ }^{* * *}$. Panel $\mathrm{D}$ : Immunohistochemistry analysis of ACTA2 protein expression in untreated ([-]RA [-]puro), retinoic acid treated ([+]RA [-]puro) and retinoic acid and puromycin treated ([+]RA [+]puro) A404 cells.

Supplementary Figure 1: Changes in gene expression in response to retinoic acid treatment and combined retinoic acid/puromycin treatment in A404 cells. Panel A: Expression of smooth muscle marker genes smooth muscle $\alpha$-actin (ACTA2), transgelin 1 (SM22) and smooth muscle myosin heavy chain (MYH11) in response to treatment with retinoic acid for 3 days (d3 [+]RA) and after treatment with retinoic acid for 3 days and treatment with puromycin for another 3 days (d6 [+]RA). Data are shown as fold change in expression from untreated cells at day 3 (d3 [-]RA). Expression data were correlated with the expression of the reference gene GAPDH. Panel B: Expression of ACTA2, SM22 and MYH11 correlated with the reference gene $\beta$-actin. Panel C: Expression of Dnmt1, 3a and $3 b$ and Oct4 in response to 
treatment with retinoic acid for 3 days (d3 [+]RA) and after treatment with retinoic acid for 3 days and treatment with puromycin for another 3 days (d6 [+]RA). Data are shown as fold change in expression from untreated cells at day 3 (d3 [-]RA). Expression data were correlated with the expression of the reference gene GAPDH. Panel D: Expression of ACTA2, SM22 and MYH11 in response to retinoic acid treatment for 1, 2, and 3 days. Data are shown as fold change in expression from untreated cells at day 3 (d3 [-]RA). Expression data were correlated with the expression of the reference gene GAPDH.

Supplementary Figure 2: Expression data for the smooth muscle marker genes ACTA2 (panel A) and SM22 (panel B), the differentiation marker Oct4 (panel C) and the Dnmt1, 3a and 3b genes (panels $D$ to $F$ ) in response to treatment of A404 cells with retinoic acid for $48 \mathrm{~h}$ or $96 \mathrm{~h}$ or treatment with retinoic acid for $96 \mathrm{~h}$ with subsequent puromycin selection (96h-P). Data are derived from Spin et al. 2010 via the Gene Expression Omnibus at the NCBI. 3 different probe sets, representing variations in the expression of splice variants are shown for Dnmt3a.

Figure 3: Impact of azacytidine treatment on cell proliferation and global DNA methylation. A404 cells were grown in medium containing $0.1 \mu \mathrm{M}, 1 \mu \mathrm{M}$ or $10 \mu \mathrm{M}$ of azacytidine or in normal medium for 6 days. $10^{4}$ cells were seeded, and cell numbers were recorded on day 3 and 6. Genomic DNA was isolated at the end of the incubation and analysed by LC-MS. Panel A: Cell proliferation of cells grown in the different media. The number of cells was determined by trypan blue staining at the indicated time points using a haemocytometer $(n=6)$. Panel B: Global DNA methylation. The percentage of methylated cytosine residues is shown ( $n=3$ ). Panels C-E: Analysis of gene expression in azacytidine treated A404 cells. A404 cells were treated with azacytidine for $24 \mathrm{~h}$ and then induced with all-trans retinoic acid or equivalent concentration of solvent for 3 days in the continued presence of azacytidine. RNA was isolated, reverse transcribed and analysed by quantitative real time PCR. Expression of the smooth muscle $\alpha$-actin (ACTA2), SM22, Dnmt1, Dnmt3b and Oct4 genes was measured and correlated with expression of the reference gene GAPDH in A404 cells treated with different concentrations of azacytidine. Expression is show as fold change from control cells (not treated with azacytidine). Panel C: Fold induction of the ACTA2, SM22, Dnmt1, Dnmt3b and Oct4 genes in response to azacytidine treatment without retinoic acid. Panel D: Fold induction of the ACTA2, SM22 and Dnmt1 genes in response to combined retinoic acid and azacytidine treatment. Panel E: Expression of the Dnmt3b and Oct4 genes in response to combined retinoic acid and azacytidine treatment. Statistical analysis was done by ANOVA $(n=3) . p<0.05:{ }^{*}, p<0.01:{ }^{* *}, p<0,001:{ }^{* * *}$.

Figure 4. Impact of folate and vitamin B6/12 deficiency on A404 cells. Panels A-B: Proliferation of A404 cells in different cell culture media as determined by trypan blue staining at the indicated time points using a haemocytometer. Cells were grown in medium containing 100, 100, 10 or $0 \mathrm{ng} / \mathrm{ml}$ of folate either in the presence of B-vitamins (Panel A) or in their absence (Panel B). The folate deficient medium $(0 \mathrm{ng} / \mathrm{ml})$ contains residual folate derived from foetal calf serum at a final folate concentration of $0.6 \mathrm{ng} / \mathrm{ml} .2 * 10^{4}$ A404 cells were seeded into $6 \mathrm{~cm}$ dishes and grown for 7 days. Cells were counted after 3, 5, and 7 days. The average of 4 independent experiments is shown. Panel C: Intracellular folate concentration in cells grown in folate deficient $(\mathrm{F} ; 0 \mathrm{ng} / \mathrm{ml})$ or folate and B-vitamin deficient (FB) media. Concentrations determined by radio-immunoassay are shown as pg folate per $10^{4}$ cells. Panel D: Homocysteine concentrations in cell culture medium as measured using a GC-MS method. Concentrations in $\mathrm{nM}$ per $\mu \mathrm{g}$ of DNA (isolated from the underlying cell layer) were calculated and the results are shown as percentage of homocysteine in control medium. Panel E: Global DNA methylation. The percentage of methylated cytosine residues 
is shown in medium containing $0,10,100$ or 1000 ng folic acid per $\mathrm{ml}$ either in the absence (FB) or presence of vitamins B6 and B12 (F). Panel F: Expression of the smooth muscle cell marker genes ACTA2, SM22 and MYH11 in response to F and FB media correlated to expression of the reference gene GAPDH. Results are shown as fold change of expression relative to cells in control medium (CON). Panel G: Expression of the smooth muscle cell marker genes ACTA2, SM22 and MYH11 in response to retinoic acid treatment in F and FB media relative to expression of the reference gene GAPDH. Results are shown as fold change of expression relative to untreated cells (i.e. in CON medium in the absence of retinoic acid). Measurements $(n=4)$ were analysed by one-way ANOVA. $p<0.05:{ }^{*}, p<0.01:{ }^{* *}, p<0,001$ : $* * *$.

Figure 5. Differentiation of A7r5 rat smooth muscle cells. Panel A: Micrographs of A7r5 cells at exponential growth and 3 days after reaching confluence. Cells were photographed at a magnification of 40x. Scale bar: 100um. Panel B: Western blot analysis of protein extracts from growing and confluent cells using antisera directed against $\beta$-actin (ACTB) and smooth muscle $\alpha$-actin (ACTA2). Extracts from HEK 293 cells (which do not express ACTA2) were used as negative control. Panel C: Abundance of ACTA2 protein relative to ACTB protein in proliferating and confluent A7r5 cells as quantified by densitometry. Panel $D$ : Expression of smooth muscle specific genes SM22, smooth muscle $\alpha$-actin (ACTA2), smooth muscle myosin heavy chain (MYH11), brain specific creatine kinase (CKB) and muscle specific creatine kinase (CKM) in A7r5 cells 3 days and 10 days after reaching confluence. Expression is shown as percentage of expression in proliferating cells. Statistical analysis $(n=3)$ was done by ANOVA. $\mathrm{p}<0.05:{ }^{*}, \mathrm{p}<0.01:{ }^{* *}, \mathrm{p}<0,001:{ }^{* * *}$.

Figure 6: Cellular responses to folate (F) and combined folate and B6 deficiency (FB) in A7r5 cells grown in the respective media for 21 days. Panel A: Representative microscopy pictures of $A 7 r 5$ cells grown in full medium (CON), folate deficient medium ( $F$; containing a residual concentration of $0.6 \mathrm{ng}$ folate per $\mathrm{ml}$ derived from serum) and medium deficient in folate and vitamins B6 (pyridoxal) and B12. Cells were photographed at a magnification of 100x. Scale bar: 40um. Panel B: Impact of different medium folate concentrations (from 0 to $100 \mathrm{ng} / \mathrm{ml}$ ) on cell growth over a period of 21 days (as determined by trypan blue staining at the end of the incubation period using a haemocytometer). Panel C: Growth of A7r5 cells in medium containing $10 \mathrm{ng} / \mathrm{ml}$ of folate (10F), no folate $(F)$, no folate and no vitamin $B 6(F B)$, or control medium (CON; $100 \mathrm{ng} / \mathrm{ml}$ of folate) over an 18-day period as determined by trypan blue staining at the indicated time points using a haemocytometer. Panel D: Cellular folate concentrations of cells grown in control or F or FB medium as measured by RIA. Panel E: Homocysteine concentration in medium of cells grown in control or $F$ or FB medium (measured by LC-MS) expressed as nMol of homocysteine per $\mu \mathrm{g}$ of DNA (derived from the underlying cells). Panel F: Global DNA methylation as measured by LC-MS. Results are shown as percentage of methylation in CON medium. Panel G: Expression of the smooth muscle cell marker genes ACTA2, SM22 and MYH11 in response to $F$ and FB medium correlated with expression of the reference gene GAPDH. Results are shown as fold change of expression relative to control cells. Panel H: Expression of Dnmt1 and Dnmt3a. Measurements $(n=4)$ were analysed by one-way ANOVA. p<0.05: ${ }^{*}, \mathrm{p}<0.01:^{* *}, \mathrm{p}<0,001:{ }^{* * *}$.

Supplementary Figure 3: Cellular responses to different combinations of folate and vitamin B6 content of cell culture medium. Folate concentrations were $4000 \mathrm{ng} / \mathrm{ml}$ (F:4000), 10ng/ml ( $F: 10)$ or $0 \mathrm{ng} / \mathrm{ml}$ ( $\mathrm{F}: 0$; equating to $0.6 \mathrm{ng} / \mathrm{ml}$ when the residual folate in serum is taken into account). Pyridoxal/B6 concentrations were $23 \mu \mathrm{M}$ (B6: 23, $0.1 \mu \mathrm{M}$ and $0 \mu \mathrm{M}$. Panel A: Homocysteine content of medium derived from A7r5 cells grown in different combinations of folate and vitamin B6 as measured by LC-MS expressed as nMol of homocysteine per $\mu \mathrm{g}$ 
of DNA (derived from the underlying cells). Panel B: Global DNA methylation as measured by LC-MS. Measurements $(n=4)$ were analysed by one-way ANOVA. $p<0.05:{ }^{*}, p<0.01:{ }^{* *}, p<$ $0,001:^{* * *}$.

Supplementary Figure 4: Cellular responses different combinations of folate and methionine content of cell culture medium. Folate concentrations were $4000 \mathrm{ng} / \mathrm{ml}, 10 \mathrm{ng} / \mathrm{ml}$ or $0 \mathrm{ng} / \mathrm{ml}$ (equating to $0.6 \mathrm{ng} / \mathrm{ml}$ when the residual folate in serum is taken into account). Methionine concentrations were $200 \mu \mathrm{M}, 20 \mu \mathrm{M}$ and $0 \mu \mathrm{M}$. Panel A: Impact of different combinations of folate and methionine on cell growth over a period of 11 days. Panel B: Homocysteine content of medium derived from A7r5 cells grown in different combinations of folate and methionine as measured by LC-MS expressed as nMol of homocysteine per $\mu \mathrm{g}$ of DNA (derived from the underlying cells). Panel C: Cellular folate concentrations of cells as measured by RIA. Panel D: Global DNA methylation as measured by LC-MS. Panel E: Expression of the smooth muscle cell marker genes ACTA2, and MYH11 in response to F and FM (folate and methionine deficient) medium correlated to expression of the reference gene GAPDH. Results are shown as fold change of expression relative to control cells. Measurements $(n=4)$ were analysed by one-way ANOVA. $p<0.05:{ }^{*}, p<0.01:{ }^{* *}, p<0,001$ : $* * *$.

Figure 7: Principal component analysis of a transcriptome analysis of A7r5 cells grown in medium containing $2.5 \mathrm{ng} / \mathrm{ml}$ (shown in green), $10 \mathrm{ng} / \mathrm{ml}$ (shown in orange) or $100 \mathrm{ng} / \mathrm{ml}$ of folate (shown in red) for 7, 14 and 21 days. The first principal component separates the data by day of analysis; the second principal component separates the data by folate concentration.

Figure 8: Venn diagrams of the genes changed during the different incubation periods and the different folate concentrations. Genes included were significant with a p-value $<0.001$ and a fold change of $>2$. Note that very few gene changes are found at time points between cells grown in $2.5 \mathrm{ng} / \mathrm{ml}$ and $10 \mathrm{ng} / \mathrm{ml}$.

Figure 9: Fold change of expression for 6 exemplary genes, which are highly responsive to modulations of folate concentrations in medium. Thioredoxin interacting protein (TXNIP), insulin induced gene 1 (INSIG1) and isopentenyl diphosphate isomerase (IDI1) are highly expressed in $100 \mathrm{ng} / \mathrm{ml}$ of folate but downregulated in response to folate deficiency (panels A-C). Prion protein dublet (PRND), skeletal muscle myosin heavy chain (MYH2) and skeletal muscle $\alpha$-actin (ACTA1) are induced in response to low folate concentrations (i.e. $2.5 \mathrm{ng} / \mathrm{ml}$ ) (panels D-F). Measurements $(n=5)$ were analysed by one-way ANOVA. $p<0.05:{ }^{*}, p<0.01: * *$, $p<0,001:{ }^{* * *}$.

Supplementary Figure 5: Pathway analysis using the Enrichr software suite. Panels A-C show the most significantly activated pathways detected using a list of genes activated $>2$ fold with a $\mathrm{p}$-value $<0.01$ in response to low folate supply $(2.5 \mathrm{ng} / \mathrm{ml} \mathrm{vs}$. $100 \mathrm{ng} / \mathrm{ml}$ folate at day 21). Pathways detected in the $\mathrm{NCl}$-Nature, OMIM disease and Reactome databases are shown. Panels D-F show the most significantly activated pathways detected using a list of genes activated $>2$ fold with a $p$-value $<0.01$ in response to high folate supply $(100 \mathrm{ng} / \mathrm{ml}$ vs. $2.5 \mathrm{ng} / \mathrm{ml}$ folate at day 21). Pathways detected in the NCl-Nature, WikiPathways and Reactome databases are shown.

Figure 10: Panel A: Growth of A7r5 cells in medium containing $10 \%, 0.5 \%$ and $0.1 \%$ foetal calf serum over a period of 11 days. Panel B: Growth of A7r5 cells in control medium and medium containing $0.01 \mu \mathrm{M}$ of the iron chelator deferoxamine (DFO). Panel C: Expression of 
the genes ID1, INSIG1, TXNIP1 and IDI1 which were found to be downregulated in response to folate deficiency. Gene expression was measured in cells grown in medium containing $0.5 \%$ serum (FCS), $0.01 \mu \mathrm{M}$ DFO (FE) or $0.6 \mathrm{ng} / \mathrm{ml}$ folate (F). Gene expression was correlated with expression of the reference gene $\beta$-actin. Results are shown as fold change of expression relative to control cells. Panel D: Expression of the genes MYH2, ACTA1, and PRND which were found to be upregulated in response to folate deficiency. In addition, expression of the Dnmt3a gene was measured. Measurements $(n=3)$ were analysed by oneway ANOVA. $\mathrm{p}<0.05:^{*}, \mathrm{p}<0.01:^{* *}, \mathrm{p}<0,001:^{* * *}$.

Supplementary Figure 6: Control substrates for methylation analyses. Panel A: Schematic representation of the approaches used to generate non-methylated and fully methylated genomic DNA. Panel B: Analysis of DNA methylation efficiency of the Sssl DNA methyl transferase using bacteriophage lambda DNA as template. Note that untreated lambda DNA is fully digested by BstUI (yielding 25 fragments), whereas Sssl treated DNA is fully protected against digestion. Panel C: Untreated (unmethylated) and SssI treated lambda DNA was mixed in 6 different ratios (containing 100\%, 50\%, 25\%, 12.5\%, $6.25 \%$ or $3.1 \%$ of Sssl treated DNA) and cytosine methylation was measured by LC-MS. The amount of SssI treated DNA added and percentage of methyl-cytosine measured is correlated. Panel D: Global DNA methylation as measured by LC-MS for methylated cytosine. The percentage of methylcytosine $(\% \mathrm{mC})$ is shown for DNA derived from A7r5 cells grown in control medium (CON), in medium supplemented with $10 \mu \mathrm{M}$ azacytidine, A7r5 DNA derived from whole genome amplification (WGA) or treatment with SssI (CON[+]) or DNA derived from whole genome amplification and subsequent Sss treatment (WGA[+]). Measurements $(n=3)$ were analysed by one-way ANOVA. $p<0.05:{ }^{*}, p<0.01:{ }^{* *}, p<0,001:{ }^{* *}$.

Supplementary Figure 7: Treatment of A7r5 cells with azacytidine. A7r5 cells were seeded into $6 \mathrm{~cm}$ dishes $(n=4)$ in normal medium. $24 \mathrm{~h}$ later cells the medium was changed to 4 different concentrations of azacytidine $(0.1,1,5$ or $10 \mu \mathrm{M})$ or control medium. $72 \mathrm{~h}$ later the medium was changed back to control medium. After a further $72 \mathrm{~h}$ cells were counted and genomic DNA was isolated. Panel A: Cell counts after azacytidine treatment. Panel B: Global DNA methylation as measured by LC-MS. Data were analysed by ANOVA. Error bars indicate standard deviation. $\mathrm{p}<0.05:{ }^{*}, \mathrm{p}<0.001:{ }^{* * *}$.

Figure 11: COBRA analysis of DNA methylation at LINE1 (a repetitive mobile genetic element which serves as a proxy for global DNA methylation). Panel A: Schematic representation of the LINE1 section used for DNA amplification with the primer pair LINE-1s/as (from Pogribny et al. 2006). The location of the primer binding sites, the expected PCR product and its BstUI restriction digestion products are indicated, as are the CpG nucleotides in the amplified DNA region. A BstUI site (CGCG) is maintained in methylated but not in non-methylated DNA, where it is converted to TGTG. The rate of digestion is therefore reflective of the methylation rate of both CG dinucleotides (i.e. increases in digestion signify increases in methylation). Panel B: Polyacrylamide gel analysis of BstUI digested of LINE-1 PCR product. Different ratios of non-methylated (WGA: whole genome amplification) and untreated A7r5 DNA were mixed prior to bisulfite conversion and PCR amplification (from 100:0 to 0:100). The PCR products were purified and digested with BstUl and separated on a $10 \%$ polyacrylamide gel alongside a molecular weight marker (NEB PCR marker). The sizes of the relevant DNA fragments are indicated. Panel C: Polyacrylamide gel with COBRA samples derived from A7r5 cells grown in control medium (100ng/ml folate: CON), medium containing $10 \mathrm{ng} / \mathrm{ml}$ folate (10F), medium without added folate $(0.6 \mathrm{ng} / \mathrm{ml}: \mathrm{F})$, and medium containing no added folate or vitamin B6 (FB). Panel D: Quantification of DNA methylation after image analysis of the gel shown in panel $B$. The percentage of methylated input DNA is 
correlated with DNA methylation measured by BstUI digestion. Panel E: Quantification of DNA methylation after image analysis of the gel shown in panel C. Panel F: Quantification of DNA methylation in A7r5 cells treated with folate deficient medium $(F)$, iron deficient medium (FE) or medium with $0.5 \%$ FCS (FCS) as measured by COBRA analysis of the LINE1 element. Measurements $(n=3)$ were analysed by one-way ANOVA. $p<0.05$ : *.

Supplementary Figure 8: COBRA analysis of DNA methylation at LINE1. Panel A: Schematic representation of the LINE1 section used for DNA amplification with the primer pair LINE1s/as (from Pogribny et al. 2006; table 2). The location of the primer binding sites, the expected PCR product and its Rsal restriction digestion products are indicated, as are the CpG nucleotides in the amplified DNA region. The Rsal (recognition sequence GTAC) site is generated by bisulfite conversion of the original sequence GCACG to a GTACG, but only maintained if the $C G$ dinucleotide at the end of the recognition site is maintained. Therefore, digestion of the Rsal site is reflective of an increase of methylation at this CG site. Panel B: Polyacrylamide gel analysis of Rsal digested of LINE-1 PCR product. Different ratios of nonmethylated (WGA: whole genome amplification) and untreated A7r5 DNA were mixed prior to bisulfite conversion and PCR amplification (from 100:0 to 0:100). The PCR products were purified and digested with Rsal and separated on a $10 \%$ polyacrylamide gel alongside a molecular weight marker (NEB PCR marker). The sizes of the relevant DNA fragments are indicated. Panel C: Polyacrylamide gel with COBRA samples derived from A7r5 cells grown in control medium (100ng/ml folate: $\mathrm{CON}$ ), medium containing $10 \mathrm{ng} / \mathrm{ml}$ folate (10F), medium without added folate $(0.6 \mathrm{ng} / \mathrm{ml}: \mathrm{F})$, and medium containing no added folate or vitamin B6 (FB). Panel D: Quantification of DNA methylation after image analysis of the gel shown in panel C. The percentage of methylated input DNA is correlated with DNA methylation measured by Rsal digestion. Measurements $(n=3)$ were analysed by one-way ANOVA. p<0.05: *.

Supplementary Figure 9: COBRA analysis of DNA methylation at the first exon of the estrogen receptor alpha (ERa) gene. Panel A: Schematic representation of the ERa gene used for DNA amplification with the primer pair ERa-e1 s/as (from Monje et al. 2007, table 2) [34]. The location of the primer binding sites, the expected PCR product and its BstUI restriction digestion products are indicated, as are the $\mathrm{CpG}$ nucleotides in the amplified DNA region. Panel B: Polyacrylamide gel analysis of BstUI digested ERa PCR product. Different ratios of non-methylated (WGA: whole genome amplification) and untreated A7r5 DNA were mixed prior to bisulfite conversion and PCR amplification (from 100:0 to 0:100). The PCR products were purified and digested with BstUI and separated on a $10 \%$ polyacrylamide gel alongside a molecular weight marker (NEB PCR marker). The sizes of the relevant DNA fragments are indicated. Panel C: Polyacrylamide gel with COBRA samples derived from A7r 5 cells grown in control medium (100ng/ml folate: $\mathrm{CON}$ ), medium containing $10 \mathrm{ng} / \mathrm{ml}$ folate (10F), medium without added folate $(0.6 \mathrm{ng} / \mathrm{ml}: \mathrm{F})$, and medium containing no added folate or vitamin B6 (FB). Panel D: Quantification of DNA methylation after image analysis of the gel shown in panel C. The percentage of methylated input DNA is correlated with DNA methylation measured by BstUI digestion. Measurements $(n=3)$ were analysed by one-way ANOVA. $\mathrm{p}<0.05$ : $^{*}$.

Supplementary Figure 10: DNA methylation and activity of the CMV promoter. Panel A: Fluorescent microscope picture of A404 cells stably transfected with the plasmid CMV-nGFP carrying a GFP gene linked to a nuclear localisation signal under the control of the CMV promoter. Panel B: Fluorescent microscope picture of HEK293 cells stably transfected with the plasmid CMV-nGFP. Panel C: Schematic representation of the CMV promoter region used for DNA amplification with the primer pair CMV-BSP-s and CMV-BSP-as. The location of 
the primer binding sites, the expected PCR product and its SfaNI restriction digestion products are indicated. Panel D: Polyacrylamide gel analysis of SfaNI digested CMV PCR product. Different ratios of non-methylated (WGA: whole genome amplification) and untreated genomic DNA (derived from transfected HEK293 cells) were mixed prior to bisulfite conversion and PCR amplification (from 100:0 to 0:100). The PCR products were purified and digested with $\mathrm{SfaNI}$ and separated on a $10 \%$ polyacrylamide gel alongside a molecular weight marker (NEB PCR marker). The sizes of the relevant DNA fragments are indicated. Panel E: Polyacrylamide gel analysis of SfaNI digested CMV PCR product amplified from genomic DNA of 4 independent stable CMV-nGFP cell clones derived from HEK293 and A404 cells.

Figure 12: COBRA analysis of DNA methylation at the rat PRND gene. Panel A: Schematic representation of the PRND gene section used for DNA amplification with the primer pair PP2-s and PP2-as. The location of the primer binding sites, the expected PCR product and its BstUI restriction digestion products are indicated, as are the $\mathrm{CPG}$ nucleotides in the amplified DNA region. Panel B: Polyacrylamide gel analysis of BstUI digested PRND PCR product amplified from A7r5 cells grown in control medium (100ng/ml folate: CON), folate deficient medium (F), iron deficient medium (FE) or medium with $0.5 \%$ FCS (FCS). The PCR products were purified and digested with BstUI and separated on a $10 \%$ polyacrylamide gel. The sizes of the relevant DNA fragments are indicated. Panel C: Quantification of DNA methylation after image analysis of the gel shown in panel $B$. The percentage of methylated input DNA is correlated with DNA methylation measured by BstUI digestion. Measurements $(n=3)$ were analysed by one-way ANOVA. $p<0.01{ }^{* *}$.

Supplementary Figure 11: Schematic representation of the MYH2, ACTA1, ID1, PRND, INSIG1, IDI1 and TXNIP genes regulated by folate supply in A7r5 cells. The mRNA, coding sequences (CDS), the predicted CPG islands and the regions used for pyrosequencing analysis are indicated.

Figure 13: Pyrosequencing analysis of $C p G$ islands of the ACTA1 (panel A), MYH2 (panel B), INSIG1 (panel C), TXNIP (panel D), ID1 (panel E), IDI1 (panel F) and PRND genes (panels G and $\mathbf{H}$ ). Genomic DNA was derived from A7r5 cells grown in low serum (0.5\% FCS; indicated as FCS), iron deficiency (10 $\mu \mathrm{M}$ DFO; indicated as FE) or folate deficiency (0.6nM folate; indicated as F). The percentage of methylated $\mathrm{Cs}$ at each of the polymorphism positions is indicated. Panel G: Quality control of the pyrosequencing analysis for the Prnd gene. Different ratios of non-methylated (WGA: whole genome amplification) and untreated A7r5 DNA were mixed prior to bisulfite conversion and PCR amplification (from 100:0 to 0:100) before being analysed by pyrosequencing at the Prnd gene. Data are the average of 3 independent replicates and were analysed by ANOVA. $p<0.05:$.

Supplementary Figure 12: Pyrosequencing analysis of $\mathrm{CpG}$ rich regions of the MYH2 (panel A), PRND (panel B), TXNIP (panel C), and IDI1 (panel D) genes. Genomic DNA was derived from A7r5 cells grown in folate and vitamin B6 deficient medium (FB) or $10 \mathrm{mM}$ azacytidine (as outlined in suppl. Fig. 7; AZA). The percentage of methylated Cs at each of the polymorphism positions is indicated. Data are the average of 3 independent replicates and were analysed by ANOVA. $\mathrm{p}<0.05:^{*}, \mathrm{p}<0.01:^{* *}, \mathrm{p}<0.001:^{* * *}$. 
Table 1: Oligonucleotides used for quantitative PCR. Primer sequences, annealing temperatures and expected product sizes are given.

\begin{tabular}{|c|c|c|c|c|c|}
\hline gene ID & $\begin{array}{l}\text { primer } \\
\text { name }\end{array}$ & primer sequence & annealing & product & Genbank \\
\hline \multirow[t]{2}{*}{ rat MYH11 } & rsmMYH3 & CTGGGGAGCTGCGTGTC & $57.4^{\circ} \mathrm{C}$ & $530 \mathrm{bp}$ & NM_001170600.1 \\
\hline & rsmMYH4 & AGCGGCCTTCTCCTCATACTG & & & \\
\hline \multirow[t]{2}{*}{ rat CKB } & rbCK1 & AGAAAGGGGGCAACATGAAGGAAG & $58.3^{\circ} \mathrm{C}$ & $482 \mathrm{bp}$ & NM_012529.3 \\
\hline & $\mathrm{rbCK} 2$ & GCACTGCCCGGGTAATAAG & & & \\
\hline \multirow[t]{2}{*}{ rat CKM } & rmCK1 & GCGTGGGCCTGCAGAAGATTGA & $62.9^{\circ} \mathrm{C}$ & $441 \mathrm{bp}$ & NM_012530.2 \\
\hline & rmCK2 & TCCAGGGGGCGGGGCTCCAG & & & \\
\hline \multirow[t]{2}{*}{ rat TAGLN } & rSM22-1 & ATGGCGTGATTCTGAGCAAGTT & $57^{\circ} \mathrm{C}$ & $415 \mathrm{bp}$ & NM_031549.2 \\
\hline & rSM22-2 & GGTCGCCCATAGCCTGTC & & & \\
\hline \multirow[t]{2}{*}{ rat ACTA2 } & rsm-a-actin1 & CTGGCCGAGATCTCACCGACTACC & $59.6^{\circ} \mathrm{C}$ & 490bp & NM_031004.2 \\
\hline & rsm-a-actin2 & GAGCCGCCGATCCAGACAGAATA & & & \\
\hline \multirow[t]{2}{*}{ rat GAPDH } & rGAPDH3 & GCTTTCCAGAGGGGCCATCCACA & $59^{\circ} \mathrm{C}$ & $426 \mathrm{bp}$ & NM_017008.4 \\
\hline & rGAPDH4 & ACGGCAAGTTCAACGGCACAGTCA & & & \\
\hline \multirow[t]{2}{*}{ rat DNMT1 } & rDnmt1-3 & GTGCCTGCCAGCTGAGTGTTGTG & $60^{\circ} \mathrm{C}$ & $483 \mathrm{bp}$ & NM_053354.3 \\
\hline & rDnmt1-4 & ACCAGGGGATGAGCGTGTTGAAT & & & \\
\hline \multirow[t]{2}{*}{ rat DNMT3a } & rDnmt3a-1 & GCACGGGCCGCCTCTTCTT & $60^{\circ} \mathrm{C}$ & $502 \mathrm{bp}$ & NM_001003957.1 \\
\hline & rDnmt3a-2 & CACGATCGGCCCAGCAGTCTCT & & & \\
\hline \multirow[t]{2}{*}{ rat DNMT3b } & rDnmt3b-1 & AGCCAGGAGACGCGAGAACAAAAG & $60^{\circ} \mathrm{C}$ & $412 \mathrm{bp}$ & NM_001003959.1 \\
\hline & rDnmt3b-2 & ACCCACCAGCACCTCCAGACACTC & & & \\
\hline \multirow[t]{2}{*}{ rat INSIG1 } & rlnsig1-1 & TCTCCTCCGCCTGGTGGGTG & $60^{\circ} \mathrm{C}$ & $268 \mathrm{bp}$ & NM_022392.1 \\
\hline & rInsig1-2 & CCCAGGCCACTTCGGGATCG & & & \\
\hline \multirow[t]{2}{*}{ rat IDI1 } & rIDI1-1 & GTTGAAGTACGGCGCTCCGCA & $60^{\circ} \mathrm{C}$ & $418 \mathrm{bp}$ & NM_053539.1 \\
\hline & rIDI1-2 & AGCGCTTCTGTGCTGCTCGTTT & & & \\
\hline \multirow[t]{2}{*}{ rat LUM } & rLum1 & GCCCGCTGGCCTTCCAACAT & $55^{\circ} \mathrm{C}$ & $350 \mathrm{bp}$ & NM_031050.1 \\
\hline & rLum2 & GGGGATTGCCATCCAAGCGCA & & & \\
\hline \multirow[t]{2}{*}{ rat ID1 } & rIDB1 & TGTCGGAGCAAAGCGTTGCCA & $61.5^{\circ} \mathrm{C}$ & $331 \mathrm{bp}$ & NM_012797.2 \\
\hline & rIDB2 & GCTGGAACACATGCCGCCTCGG & & & \\
\hline \multirow[t]{2}{*}{ rat PRND } & rPPD1 & ACCGAAGCCCAGGTGGCTGA & $60^{\circ} \mathrm{C}$ & $373 b p$ & NM_001102431.1 \\
\hline & rPPD2 & CCAGCAGGCAGACCATCGCC & & & \\
\hline \multirow[t]{2}{*}{ rat ACTA1 } & rACTA1-1 & GGCAATGAGCGCTTCCGTTGC & $59^{\circ} \mathrm{C}$ & $392 \mathrm{bp}$ & NM_019212.2 \\
\hline & rACTA1-2 & AGACGCGGGTGCGCCTAGAAG & & & \\
\hline \multirow[t]{2}{*}{ rat MYH2 } & rMYH2-1 & TGGAGGCCAGAGTGCGTGAAC & $55^{\circ} \mathrm{C}$ & $436 \mathrm{bp}$ & NM_001135157.1 \\
\hline & rMYH2-2 & CACATGGGGACATGACCAAAGGC & & & \\
\hline \multirow[t]{2}{*}{ rat TXNIP } & rTIP-1 & AGTGGGTACACCCCCGCCTC & $55^{\circ} \mathrm{C}$ & $300 \mathrm{bp}$ & NM_001008767.1 \\
\hline & rTIP-2 & TGGCTCTGTTGCCCCATGGC & & & \\
\hline \multirow[t]{2}{*}{ mm DNMT1 } & mDnmt1-1 & GGTGGATGGCCGGGTCTACTGC & $60^{\circ} \mathrm{C}$ & $489 \mathrm{bp}$ & NM_001199431.1 \\
\hline & mDnmt1-2 & GGGCCCCCTTGTGAATAATCCT & & & \\
\hline \multirow[t]{2}{*}{ mm DNMT3a } & mDnmt3a-1 & САCCTATGGGCTGCTGCGAAGAC & $60^{\circ} \mathrm{C}$ & $419 b p$ & NM_007872.4 \\
\hline & mDnmt3a-2 & GGCGGCCAGTACCCTCATAAAGT & & & \\
\hline \multirow[t]{2}{*}{$\mathrm{mm}$ DNMT3b } & $\mathrm{mDnmt} 3 \mathrm{~b}-1$ & TGTCGGAGCAAAGCGTTGCCA & $60^{\circ} \mathrm{C}$ & $414 b p$ & NM_001003961.4 \\
\hline & mDnmt3b-2 & TGGCAGCGCTGAGGGAGGCACATA & & & \\
\hline \multirow[t]{2}{*}{$\mathrm{mm}$ Oct4 } & mOct4-1 & ACCGCCCCAATGCCGTGAAGTT & $60^{\circ} \mathrm{C}$ & $593 \mathrm{bp}$ & NM_013633.3 \\
\hline & mOct4-2 & TGGGGGCAGAGGAAAGGATACAGC & & & \\
\hline \multirow[t]{2}{*}{$\mathrm{mm}$ ACTA2 } & mACTA2 & AGTCGCTGTCAGGAACCCTGAGACG & $57^{\circ} \mathrm{C}$ & $296 \mathrm{bp}$ & NM_007392.3 \\
\hline & mACTA2 & ATCTTTTCCATGTCGTCCCAGTTG & & & \\
\hline mm MYH11 & mMYH11-1 & AGGAAACACCAAGGTCAAGCA & $57^{\circ} \mathrm{C}$ & $324 b p$ & NM_013607.2 \\
\hline & mMYH11-2 & CCCTGACATGGTGTCCAATC & & & \\
\hline mm SM22 & mSM22a-1 & TCCAGTCCACAAACGACCAAGC & $57^{\circ} \mathrm{C}$ & $328 \mathrm{bp}$ & NM_011526.5 \\
\hline & mSM22a-2 & GAATTGAGCCACCTGTTCCATCTG & & & \\
\hline
\end{tabular}


Table 2: Oligonucleotides used for COBRA analyses

\begin{tabular}{|c|c|c|c|c|c|}
\hline gene ID & $\begin{array}{l}\text { primer } \\
\text { name }\end{array}$ & primer sequence & annealing & product & Genbank \\
\hline \multirow[t]{2}{*}{ rat LINE1 } & rLINE1-s & TTTGGTGAGTTTGGGATA & $56^{\circ} \mathrm{C}$ & $163 b p$ & AC229945 \\
\hline & rLINE1-as & СТСАААААТАСССАССТААС & & & (Pogribny et al. 06) \\
\hline \multirow[t]{2}{*}{ rat $\mathrm{ER} \alpha$} & rERa-e1-s & TTTTGTTGTATTAGATTTAAGGGAA & $59^{\circ} \mathrm{C}$ & $272 b p$ & NM_012689.1 \\
\hline & rERa-e1-as & AAAAAAAACССССАААСТАТТАAC & & & (Monje et al. 07) \\
\hline \multirow[t]{2}{*}{ rat $14-3-3 \sigma$} & rSFN1-s & TTTTAGGAGTTATTTGGGTGTTGAT & $60^{\circ} \mathrm{C}$ & $229 b p$ & XM_003750048 \\
\hline & rSFN1-as & ССССТАААСТАААТААААСТАСТСТСС & & & (Chen et al. 10) \\
\hline \multirow[t]{2}{*}{ rat PRND } & rPP2-s & TTATTGGTAGTTTTTTGATGGGA & $59^{\circ} \mathrm{C}$ & $283 b p$ & NM_001102431.1 \\
\hline & rPP2-as & AAACCAAATAAAACCCAACAAA & & & \\
\hline \multirow[t]{2}{*}{ CMV } & CMV-BSP-S & TGATTTTATGGGATTTTTTTTATTT & $52^{\circ} \mathrm{C}$ & $269 b p$ & X17403.1 \\
\hline & CMV-BSP-as & СААСТСТАСТТАТАТАААССТСССА & & & \\
\hline
\end{tabular}


Table 3: Oligonucleotides used for pyrosequencing analyses and gene sequences analysed

\begin{tabular}{|c|c|c|c|c|}
\hline gene ID & $\begin{array}{l}\text { primer } \\
\text { name }\end{array}$ & sequence & annealing & product \\
\hline \multirow[t]{5}{*}{ rat ACTA1 } & ACTA1-ps-1 & TTTGGTTTTTAGTATTATGAAGATTAAGGT & $56^{\circ} \mathrm{C}$ & $205 \mathrm{bp}$ \\
\hline & ACTA1-ps-2 & АСТССТАСТTААТААТССАСАТСТАСТА & & \\
\hline & ACTA1-seq & TTTAGTATTATGAAGATTAAGGTG & & \\
\hline & sequence & GATGAYGYGT TTGGTATGGG YGGAGATTAG GGGYGGGGGG & & \\
\hline & analysed & AATTYGTAGG [+2554 to +2700 from transcriptional start] & & \\
\hline \multirow[t]{5}{*}{ rat $\mathrm{MYH} 2$} & MYH2-ps-1 & TAGATTTTGAAGGTGAAAGAAGATTAGA & $56^{\circ} \mathrm{C}$ & $178 \mathrm{bp}$ \\
\hline & MYH2-ps-2 & ACATTAAAAACCCCTAATATAAATCAC & & \\
\hline & MYH2-seq & AGATAGAGGATATGGTTATGATG & & \\
\hline & & ATTTATTTTT AYGAGTTYGT TGTGTTGTAT AATTTTAAAG & & \\
\hline & $\begin{array}{l}\text { sequence } \\
\text { analysed }\end{array}$ & $\begin{array}{l}\text { AGYGTTAYGT AGTTTGGATG ATTTAYGT [+2379 to }+2502 \\
\text { from transcriptional start] }\end{array}$ & & \\
\hline \multirow[t]{5}{*}{ rat PRND } & PRND-ps-1 & GGGATTTATTAAGAAGGTTGTTTTGAAG & $56^{\circ} \mathrm{C}$ & $221 \mathrm{bp}$ \\
\hline & PRND-ps-2 & AAACCCAACAAACAAACCA & & \\
\hline & PRND-seq & GTGATTAAGGAGGTGTT & & \\
\hline & & GGTGATTYGT TGYGTTAAYG TTATTTAGGY GGTTAATTAG & & \\
\hline & $\begin{array}{l}\text { sequence } \\
\text { analysed }\end{array}$ & $\begin{array}{l}\text { GTTGAGTTTT TTYGGGAGAA [+311 to +405 from } \\
\text { transcriptional start] }\end{array}$ & & \\
\hline \multirow[t]{5}{*}{ rat TXNIP1 } & TXNIP-ps-1 & GGTTTAATTATGGTGATGTTTAAGAAGATT & $56^{\circ} \mathrm{C}$ & $205 \mathrm{bp}$ \\
\hline & TXNIP-ps-2 & АТCTATTTACACTACTAAAACCCTTACAT & & \\
\hline & TXNIP-seq & ATGGTAGAGGGGAGAA & & \\
\hline & sequence & GGTGGTYGGT YGGGTGATAG TGGAAGTGTG TGAAGTTATT & & \\
\hline & analysed & YGAGTTAAAG TYGTTAGGAT TTTGGTTTGY G [+210 to +357] & & \\
\hline rat INSIGI & $\begin{array}{l}\text { sequence } \\
\text { analysed }\end{array}$ & $\begin{array}{l}\text { YGGAATGTTAYGTTTTTTTYGGAYGA [PM00547638] [+308 to } \\
\text { +343 from transcriptional start] }\end{array}$ & $56^{\circ} \mathrm{C}$ & $163 \mathrm{bp}$ \\
\hline rat ID1 & $\begin{array}{l}\text { sequence } \\
\text { analysed }\end{array}$ & $\begin{array}{l}\text { YGGGTAGGYGYGTTTTAGYGTAGYGYGA [PM00543697] } \\
\text { [+174 to +202 from transcriptional start] }\end{array}$ & $56^{\circ} \mathrm{C}$ & $208 \mathrm{bp}$ \\
\hline rat IDI1 & $\begin{array}{l}\text { sequence } \\
\text { analysed }\end{array}$ & $\begin{array}{l}\text { TTYGTAYGTTTAGTTGTTTTGYGGT [PM00504119] [-65 to }-23 \\
\text { from transcriptional start] }\end{array}$ & $56^{\circ} \mathrm{C}$ & $112 \mathrm{bp}$ \\
\hline
\end{tabular}


Table 4: Top 20 gene expression changes in response to folate deficiency. Fold change of gene expression between $A 7 \mathrm{r} 5$ cells grown in in folate sufficient $(100 \mathrm{ng} / \mathrm{ml})$ and folate deficient $(2.5 \mathrm{ng} / \mathrm{ml})$ medium
name
gene description
fold change Genbank

expression increased in $100 \mathrm{ng} / \mathrm{ml}$ vs $2.5 \mathrm{ng} / \mathrm{ml}$ folate

\begin{tabular}{llll}
\hline Txnip & thioredoxin interacting protein & 8.97 & U30789 \\
Itgb8 & integrin subunit beta 8, transcript variant X1 & 8.61 & XM_006240697.3 \\
\hline Lum & lumican & 8.34 & NM_031050 \\
Insig1 & insulin induced gene 1 & 8.10 & NM_022392 \\
\hline Idi1 & isopentenyl-diphosphate delta isomerase & 6.55 & NM_053539 \\
Ednra & endothelin receptor type A & 6.04 & BF414702 \\
Ptn & pleiotrophin & 5.99 & NM_017066 \\
Itgb8 & integrin subunit beta 8, transcript variant X1 & 5.97 & XM_006240697.3 \\
Scd2 & stearoyl-Coenzyme A desaturase 2 & 5.84 & NM_031841 \\
Cdc20 & cell division cycle 20 homolog & 5.44 & U05341 \\
\hline Idi1 & isopentenyl-diphosphate delta isomerase & 4.61 & BI290053 \\
LOC684841 & histone H3.2-like & 4.48 & XM_006222398.2 \\
Slc29a1 & solute carrier family 29 (nucleoside transporters), member 1 & 4.46 & NM_031684 \\
Cenpw & centromere protein W & 4.41 & NM_001246319.1 \\
Kif20a & kinesin family member 20A & 4.38 & BE111697 \\
Cdca3 & cell division cycle associated 3 & 4.34 & BF417638 \\
Nrp1 & neuropilin 1 & 4.21 & AF016296 \\
Arrdc4 & arrestin domain containing 4 & 4.18 & XM_006229367.3 \\
Hmgcs1 & 3-hydroxy-3-methylglutaryl-Coenzyme A synthase 1 & 3.93 & NM_017268 \\
\hline Kif11 & kinesin family member 11 & 3.93 & BE116384
\end{tabular}

expression increased in $2.5 \mathrm{ng} / \mathrm{ml}$ vs $100 \mathrm{ng} / \mathrm{ml}$ folate

\begin{tabular}{llll}
\hline Prnd & prion protein dublet & 24.95 & BF551984 \\
Myh2 & myosin, heavy polypeptide 2, skeletal muscle, adult & 11.52 & BI277586 \\
Id1 & inhibitor of DNA binding 1 & 9.79 & M86708 \\
Acta1 & actin, alpha 1, skeletal muscle & 9.11 & NM_019212 \\
F3 & coagulation factor III & 9.10 & NM_013057 \\
Tnnt1 & troponin T1, skeletal, slow & 8.92 & AF399874 \\
Plcxd2 & phosphatidylinositol-specific phospholipase C & 7.81 & NM_001134481.1 \\
Myh3 & myosin, heavy polypeptide 3, skeletal muscle, embryonic & 7.38 & NM_012604 \\
Id2 & inhibitor of DNA binding 2 & 6.96 & BC086391.1 \\
Scg2 & secretogranin II & 6.73 & NM_022669 \\
Vsn11 & visinin-like 1 & 6.51 & Al227991 \\
Rnf181 & ring finger protein 181 & 6.31 & Al008549 \\
Tnc & tenascin C & 6.31 & Al176034 \\
Isg12(b) & putative ISG12(b) protein & 6.13 & AA819034 \\
Prss35 & protease, serine, 35 & 5.88 & AA866443 \\
Myl2 & myosin, light polypeptide 2, regulatory, cardiac, slow & 5.38 & BF419995 \\
\hline Trib3 & tribbles homolog 3 & 5.37 & AB020967 \\
Pcp4 & Purkinje cell protein 4 & 5.10 & NM_013002 \\
\hline Ppp1r1a & protein phosphatase 1, regulatory (inhibitor) subunit 1A & 5.00 & NM_022676 \\
Plekhb2 & pleckstrin homology domain containing, family B member 2 & 4.99 & AW254369
\end{tabular}



Table 5: TOP-GO pathway analysis of transcriptome changes in response to folate deficiency. elimKS here gives the $p$-values from topGO specific Kolmogorov-Smirnov Test with elimination of genes of significant GO-terms in parent terms.

\begin{tabular}{llrrrr} 
GO.ID & Term & Annotated & Significant & Expected & elimKS \\
\hline GO:0007076 & mitotic chromosome condensation & 17 & 16 & 5.02 & $3.40 \mathrm{E}-07$ \\
\hline GO:0006695 & cholesterol biosynthetic process & 65 & 38 & 19.18 & $1.30 \mathrm{E}-06$ \\
\hline GO:0051301 & cell division & 621 & 249 & 183.24 & $1.40 \mathrm{E}-06$ \\
\hline GO:0000381 & regulation of alternative mRNA splicing & 80 & 43 & 23.61 & $2.20 \mathrm{E}-06$ \\
\hline GO:0070507 & regulation of microtubule cytoskeleton & 288 & 104 & 84.98 & $6.10 \mathrm{E}-06$ \\
\hline GO:0007059 & chromosome segregation & 412 & 188 & 121.57 & $1.10 \mathrm{E}-05$ \\
\hline GO:0034508 & centromere complex assembly & 31 & 19 & 9.15 & $1.70 \mathrm{E}-05$ \\
\hline GO:0031055 & chromatin remodelling at centromere & 14 & 12 & 4.13 & $1.70 \mathrm{E}-05$ \\
\hline GO:0045214 & sarcomere organization & 87 & 45 & 25.67 & $1.90 \mathrm{E}-05$ \\
\hline GO:0071897 & DNA biosynthetic process & 215 & 98 & 63.44 & $2.00 \mathrm{E}-05$
\end{tabular}




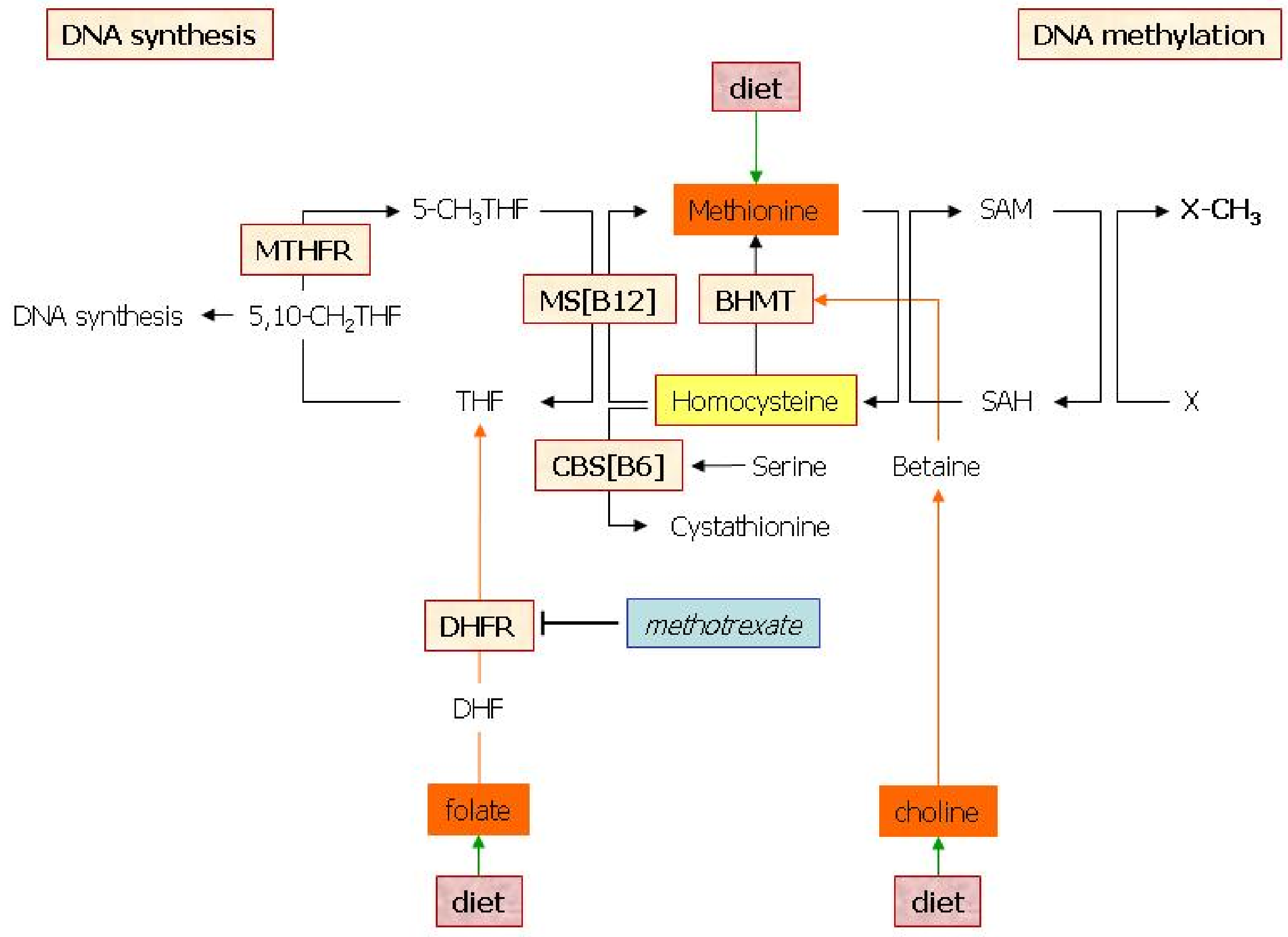


A

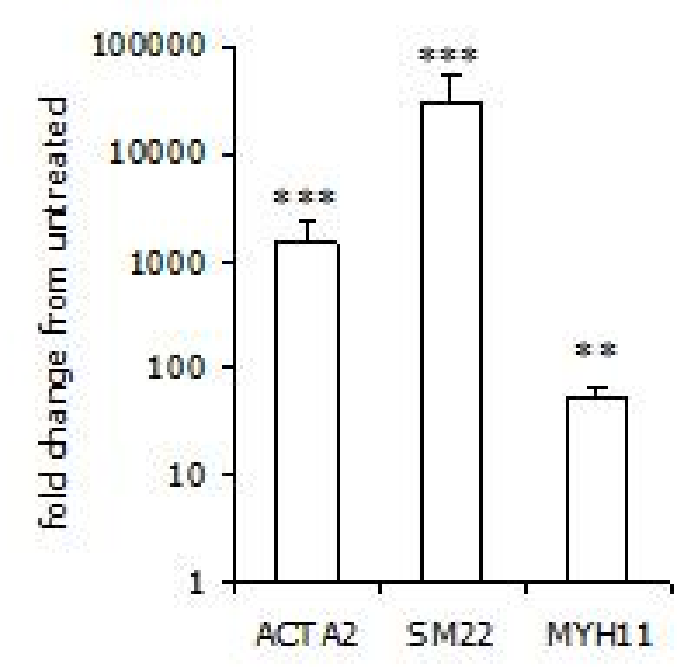

D

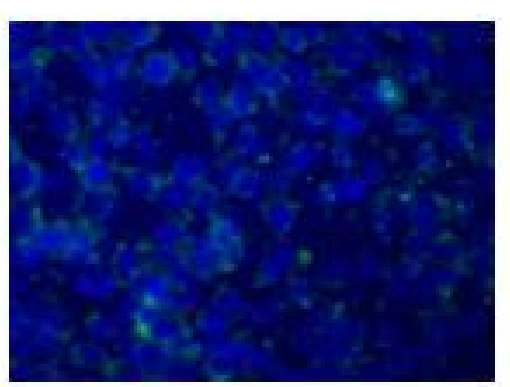

[-]RA [-]puro
B
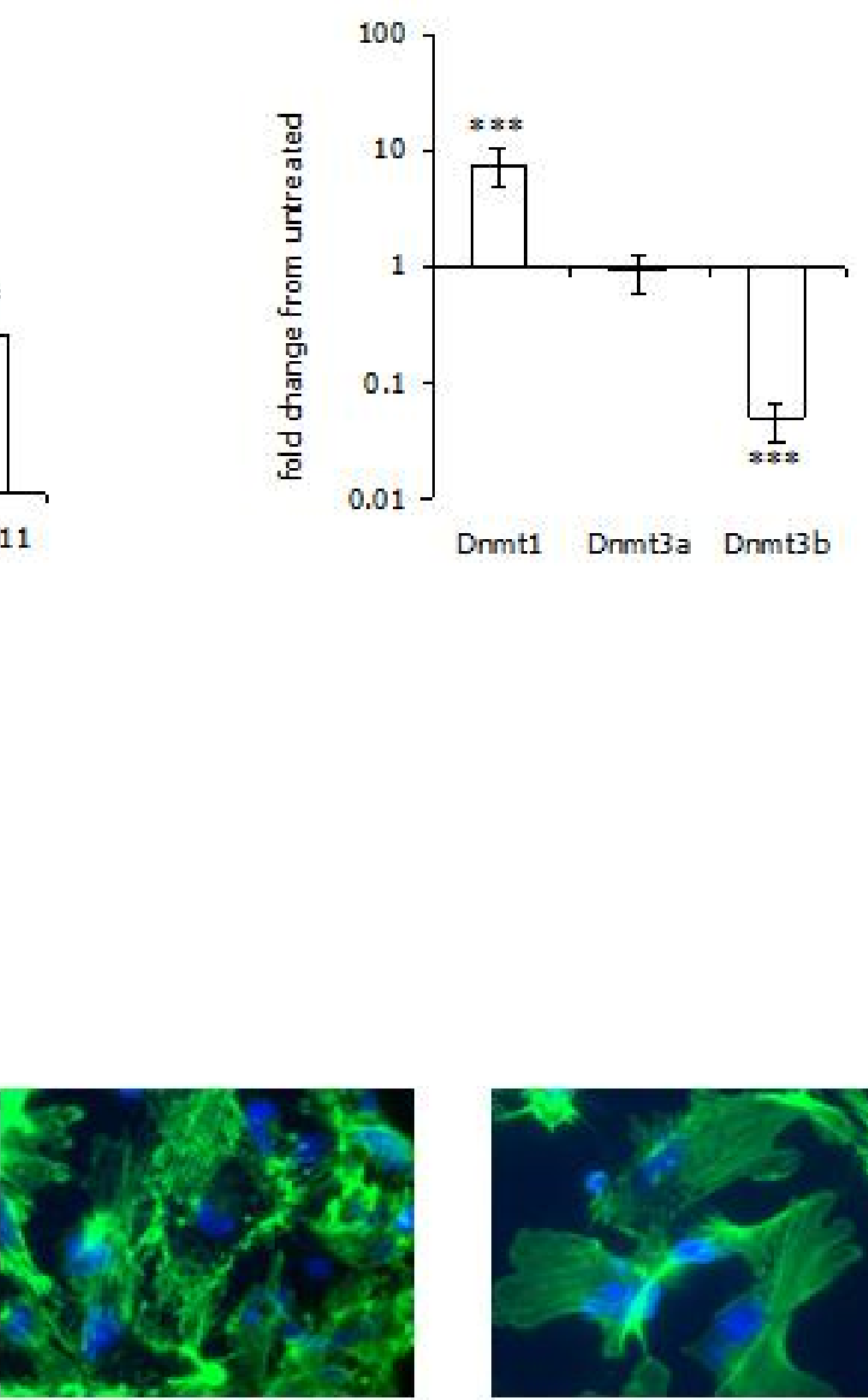

[+]RA [-]puro

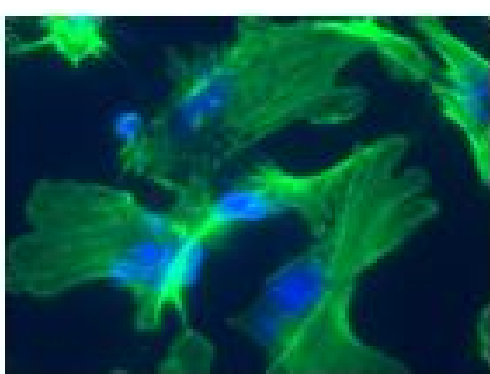

[+]RA [+]puro
C
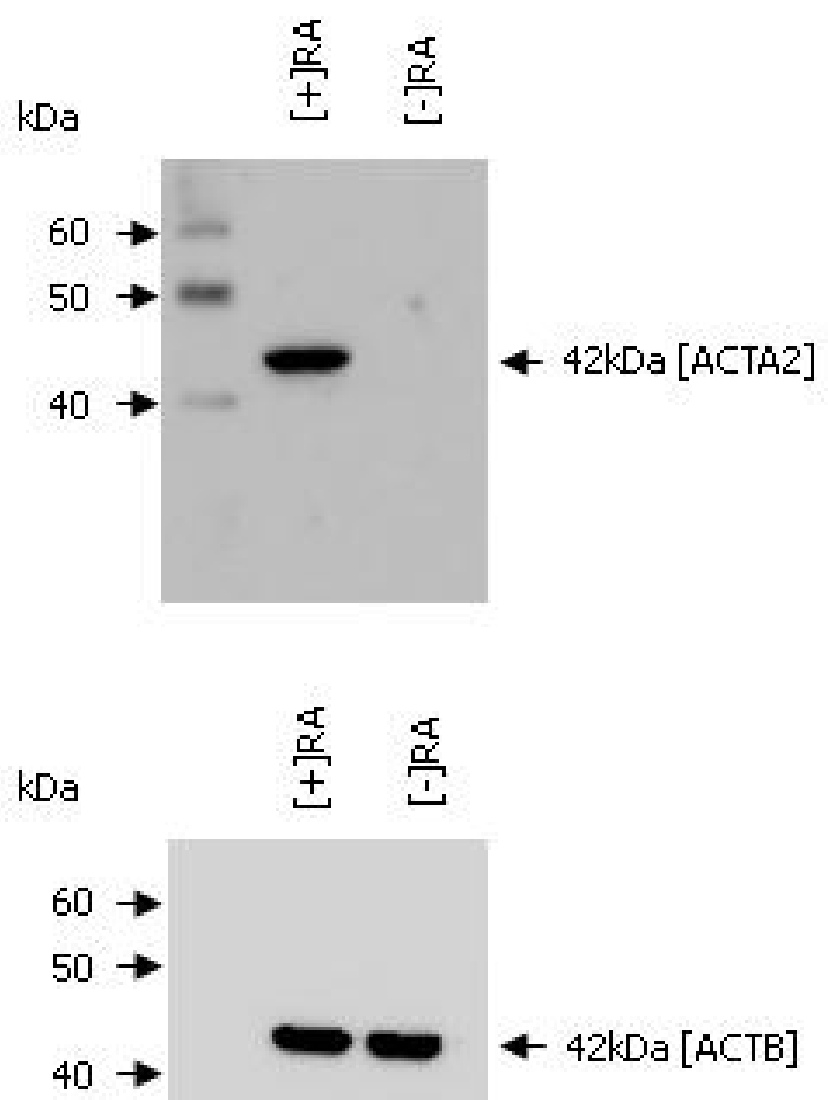
A

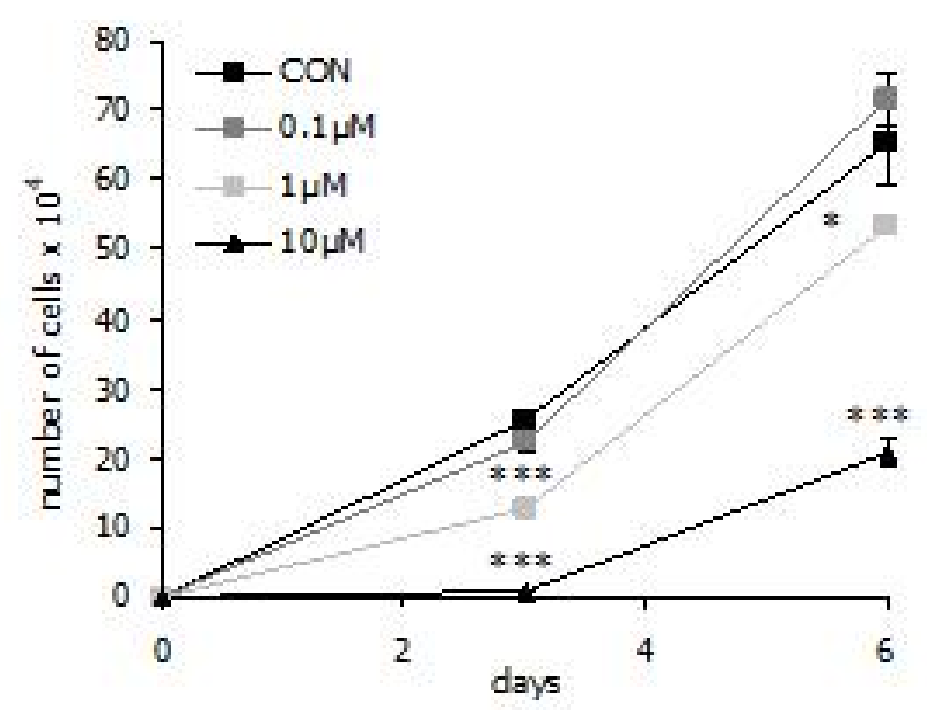

D

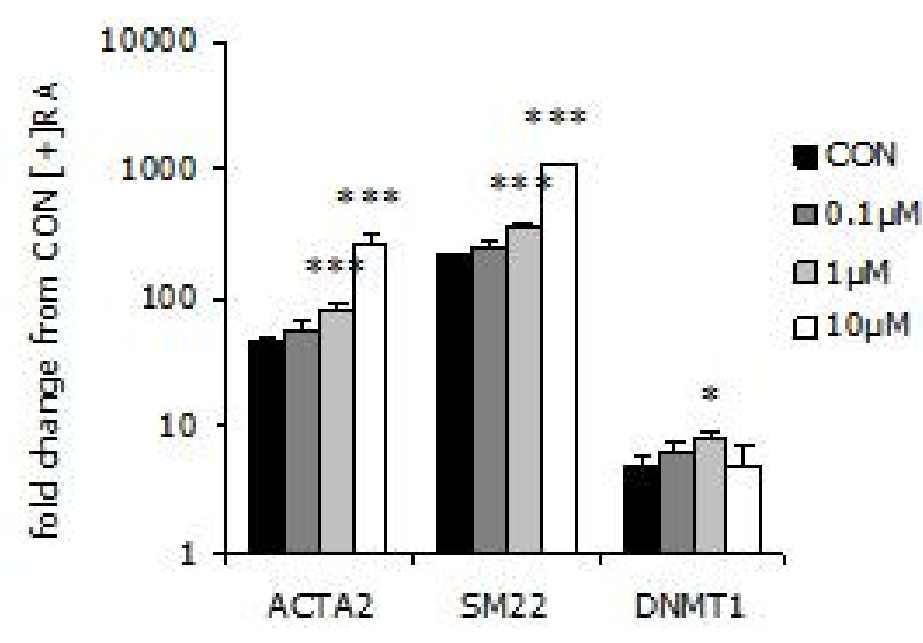

B

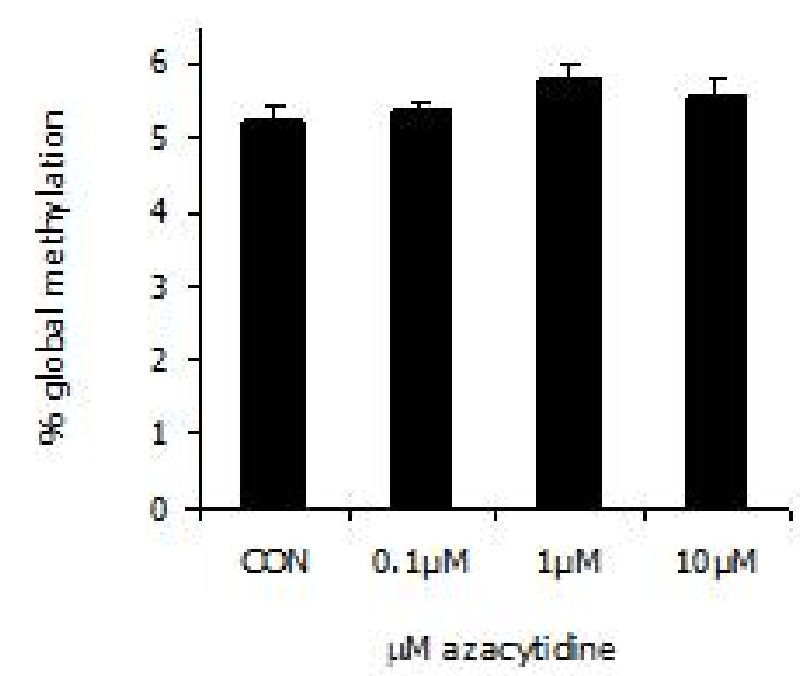

C

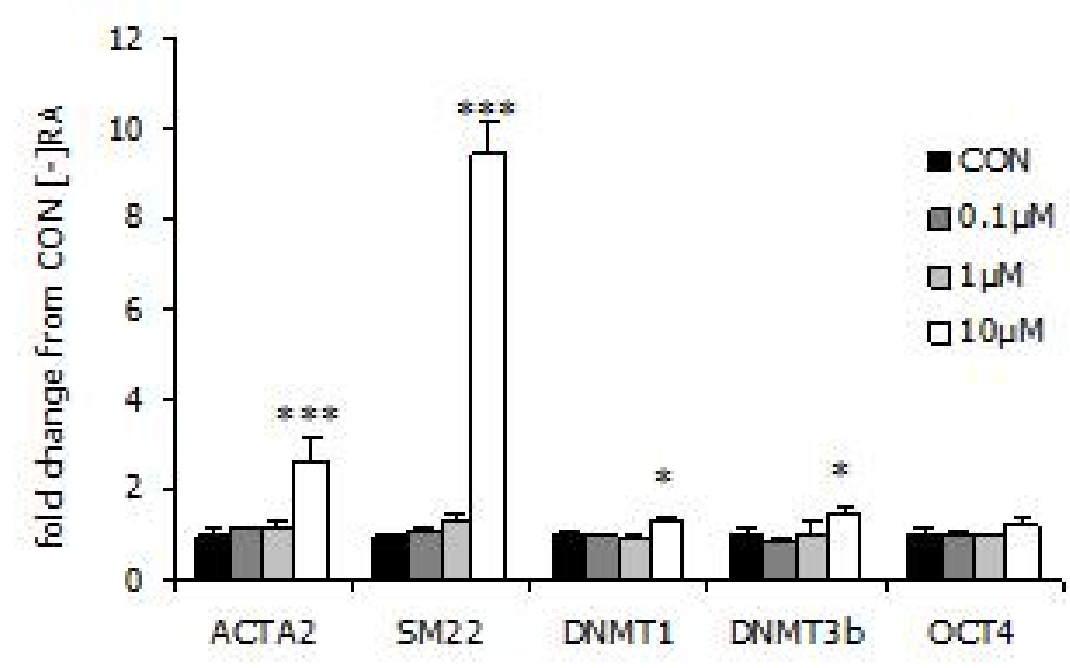

E

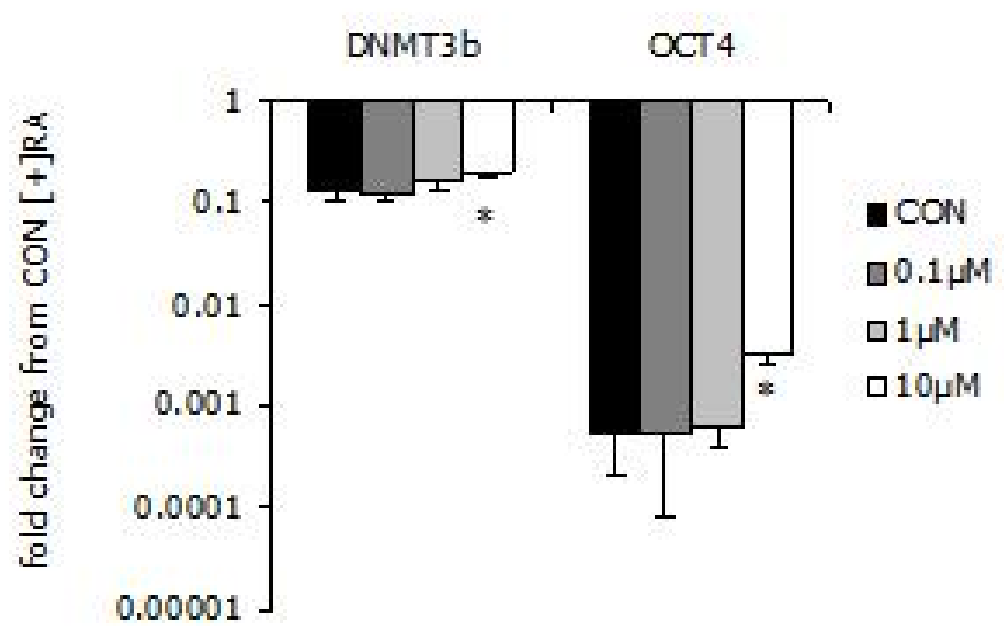


Kolb et al.; Fig. 4

A

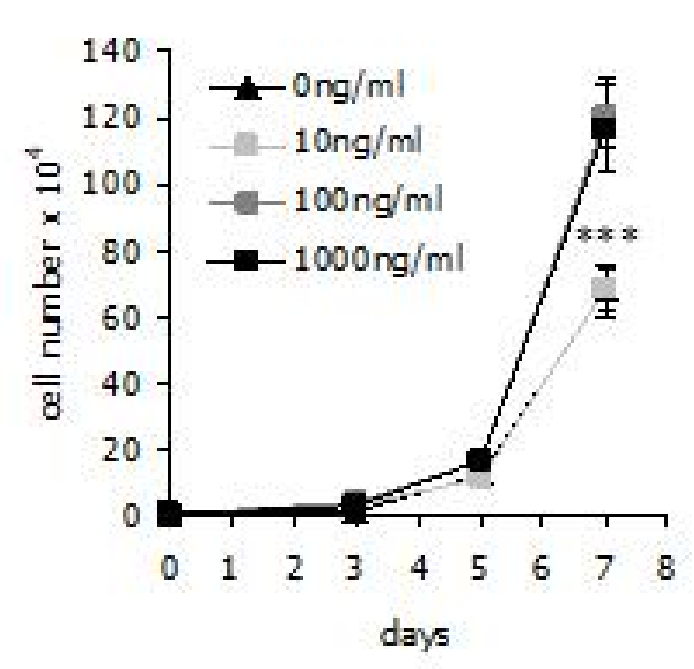

B

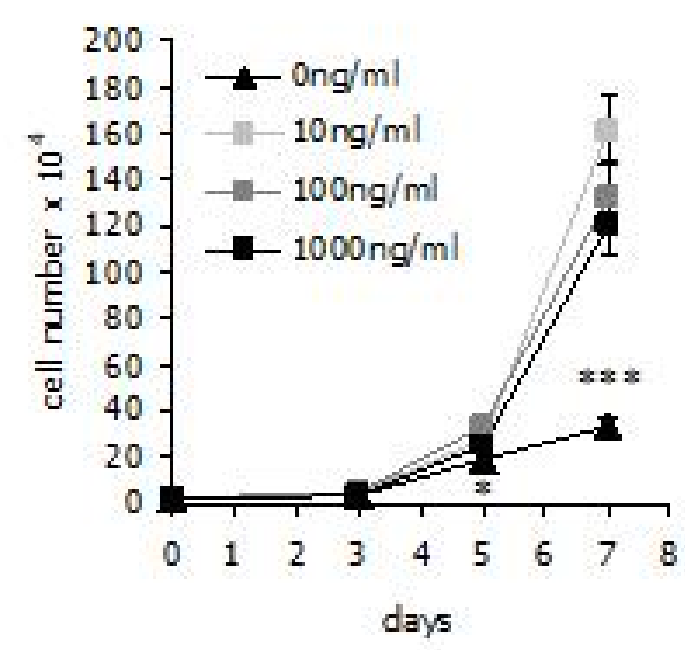

C

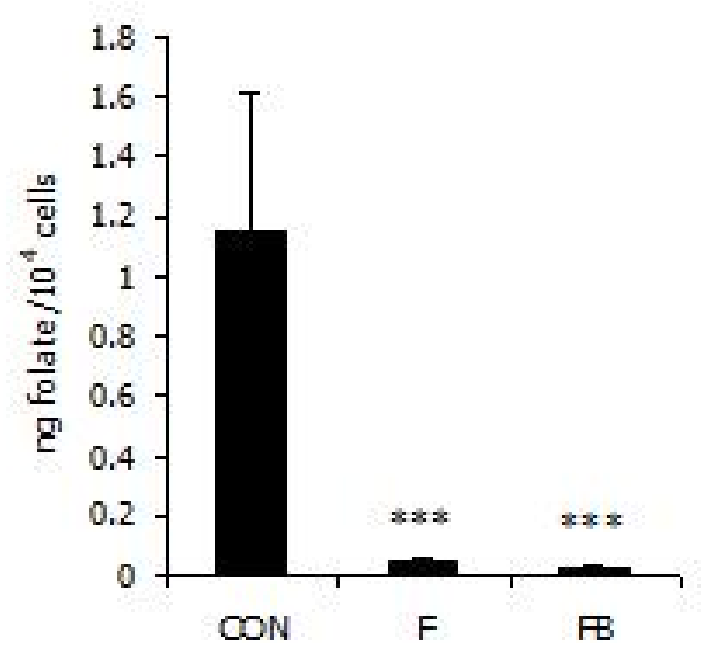

D

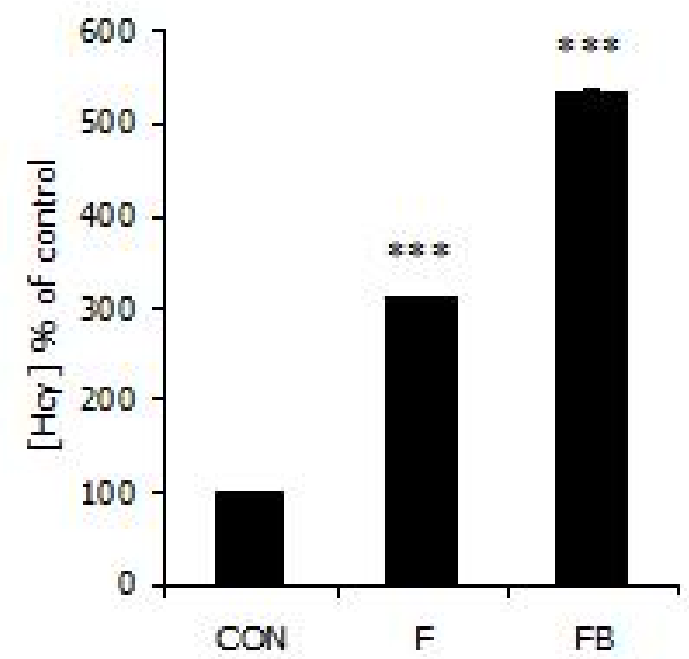

E

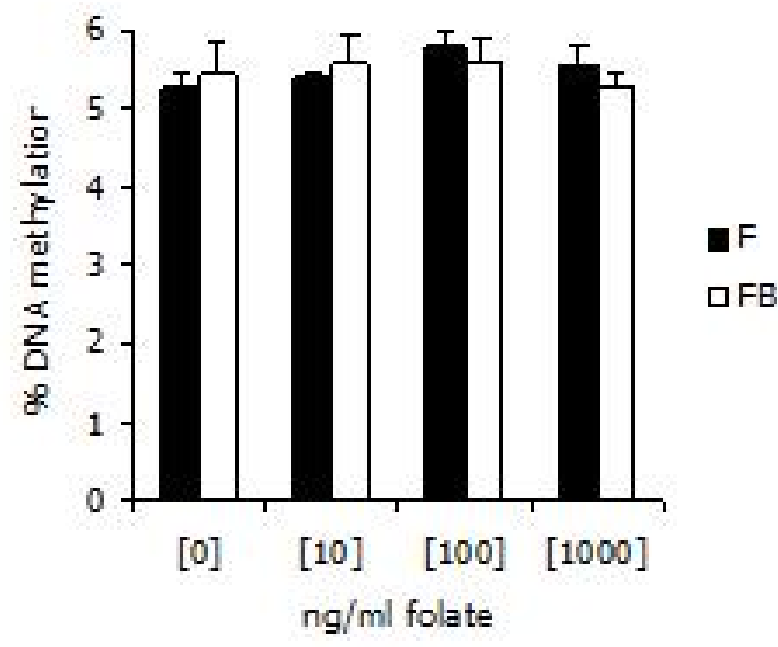

F

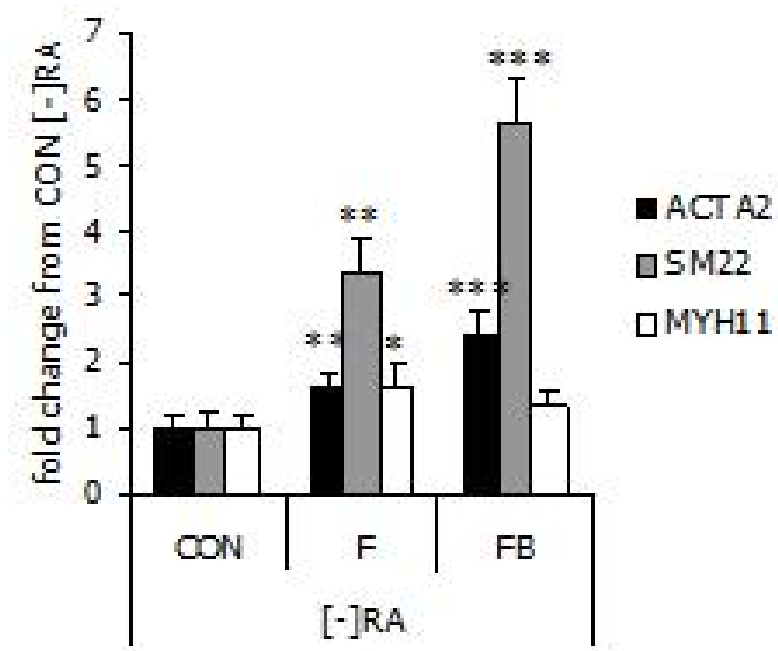

G 
A

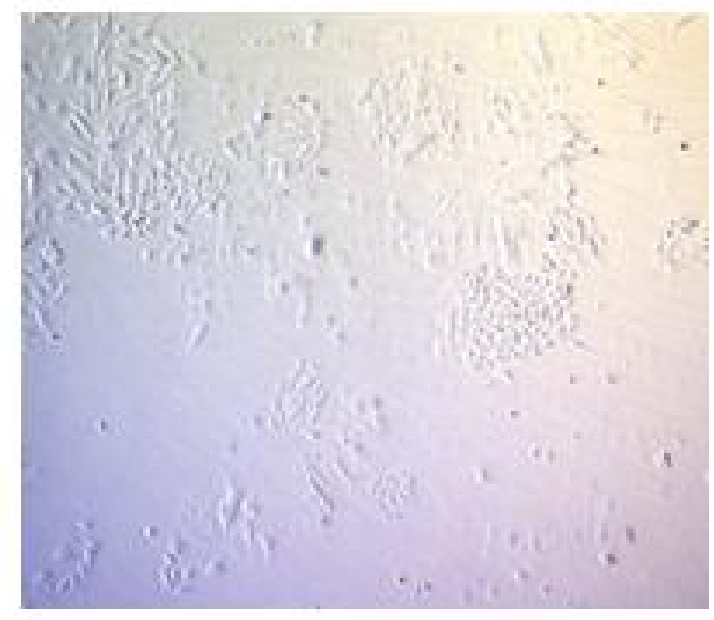

pre-corfluent

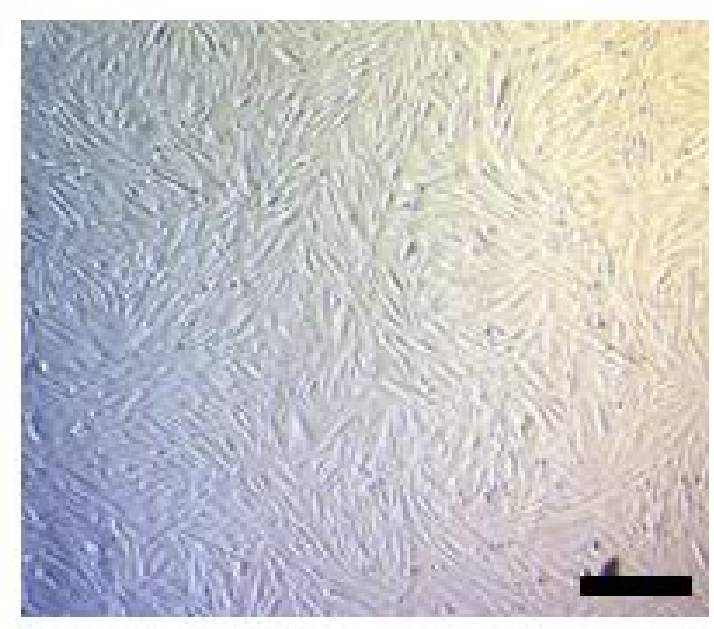

confluent
B

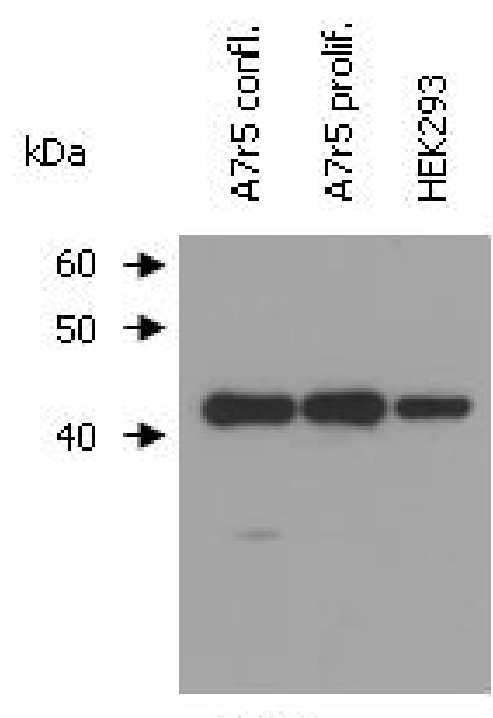

ACTB
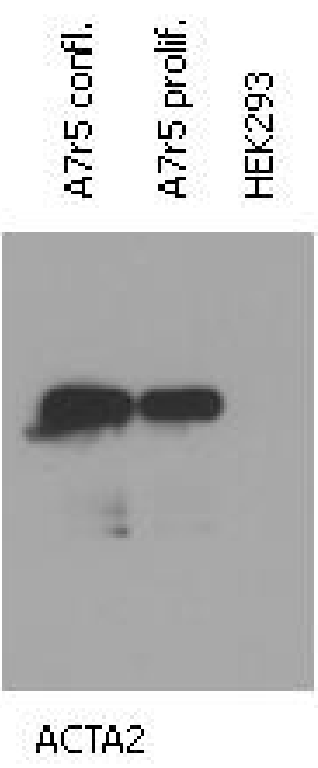

C

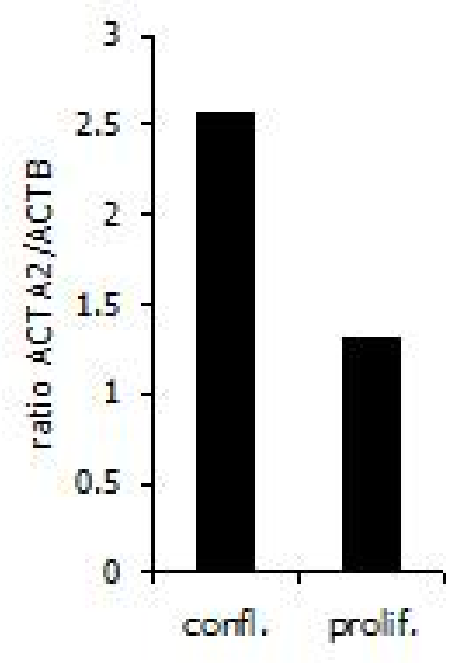

D

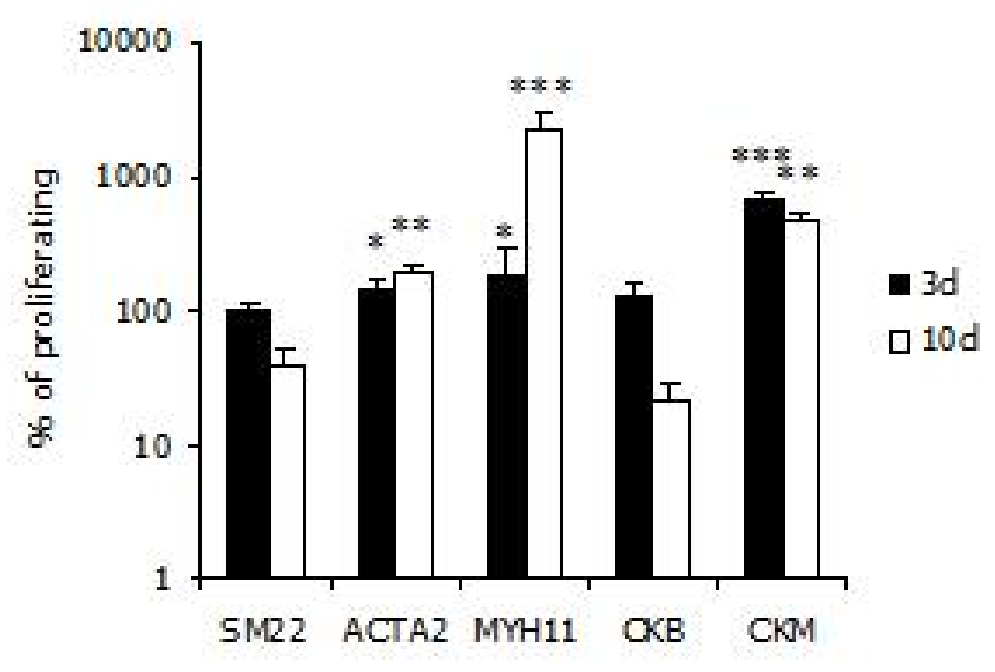


A

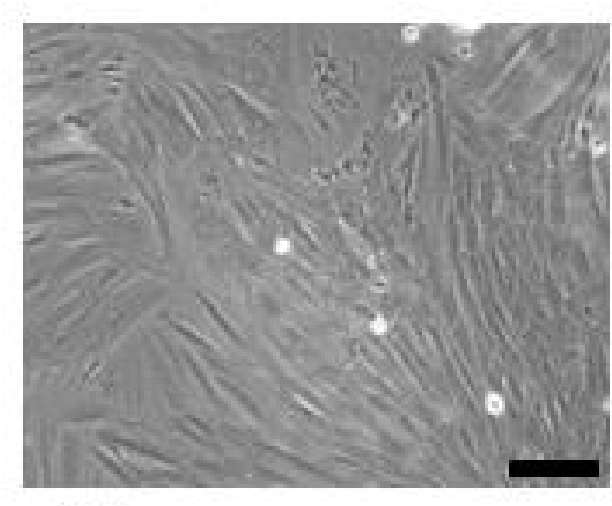

CON
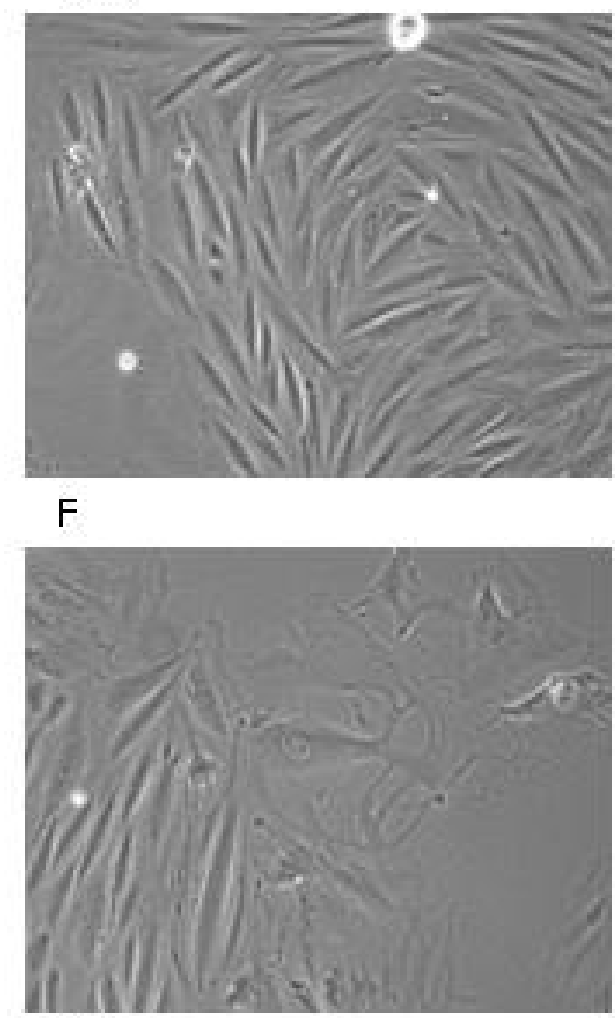

FB
B

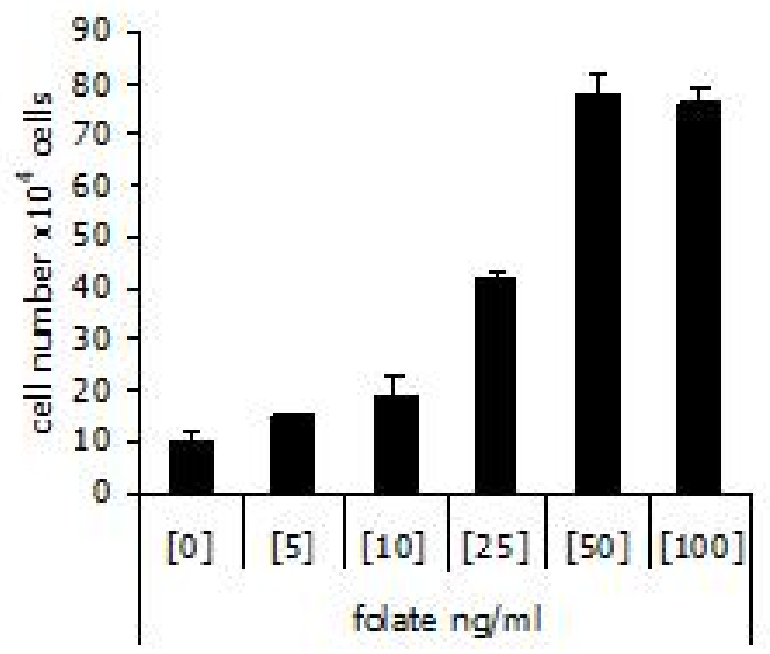

D

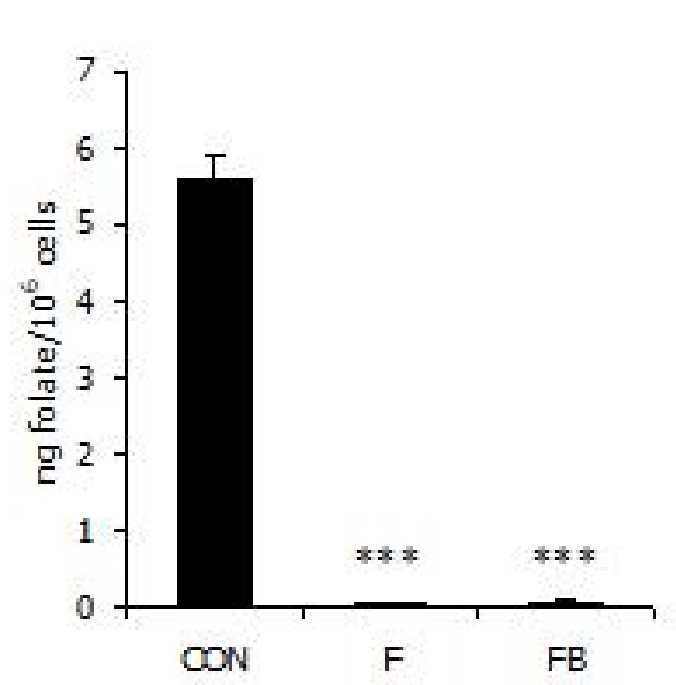

G

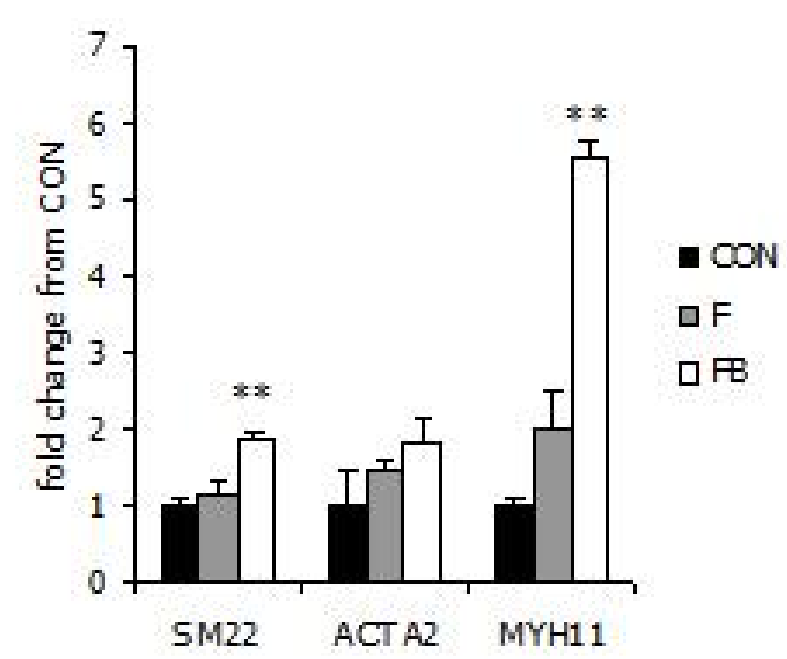

E
C
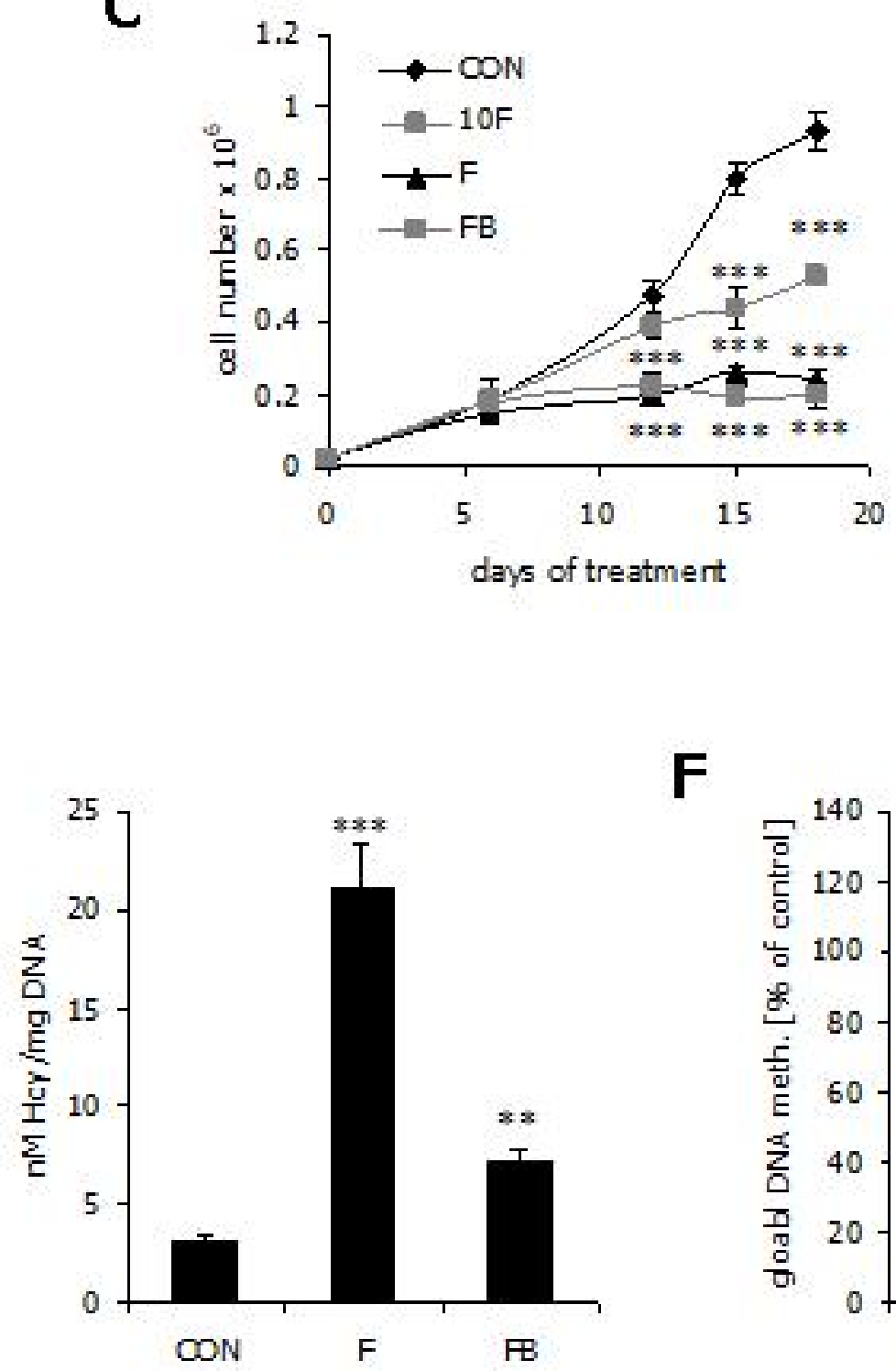

F

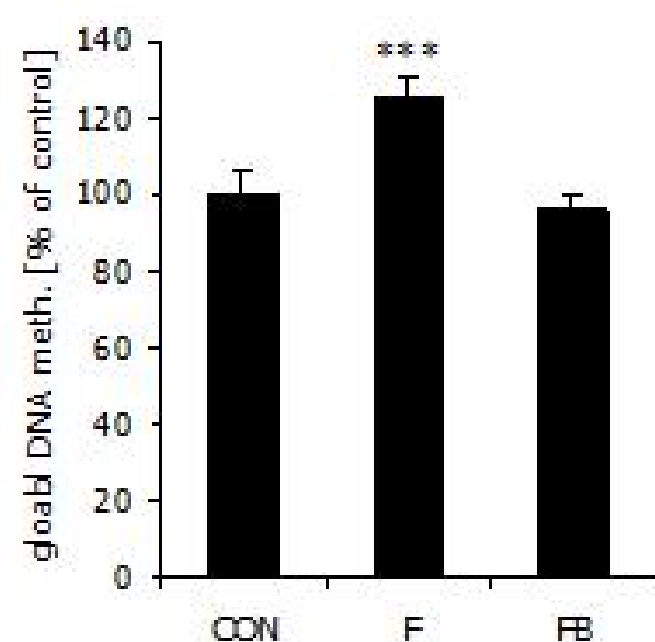

H

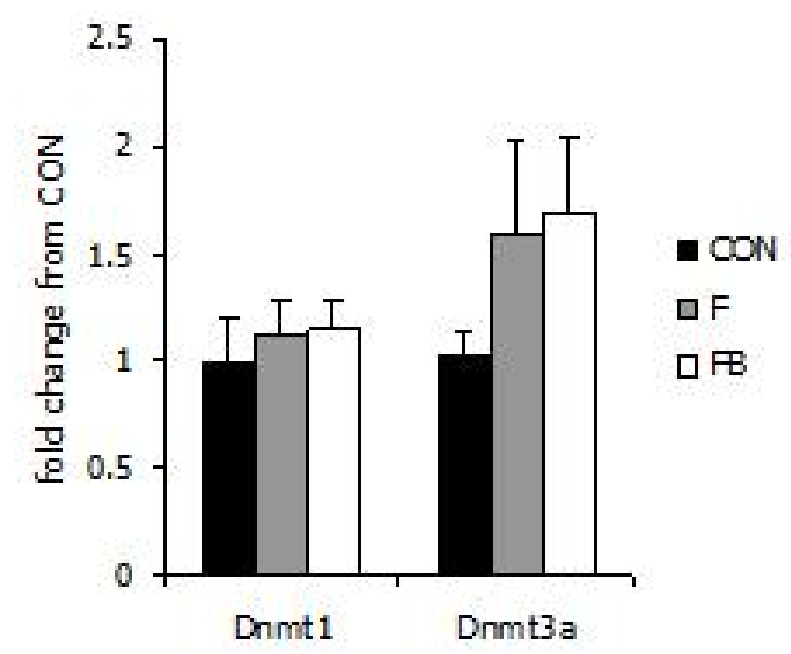




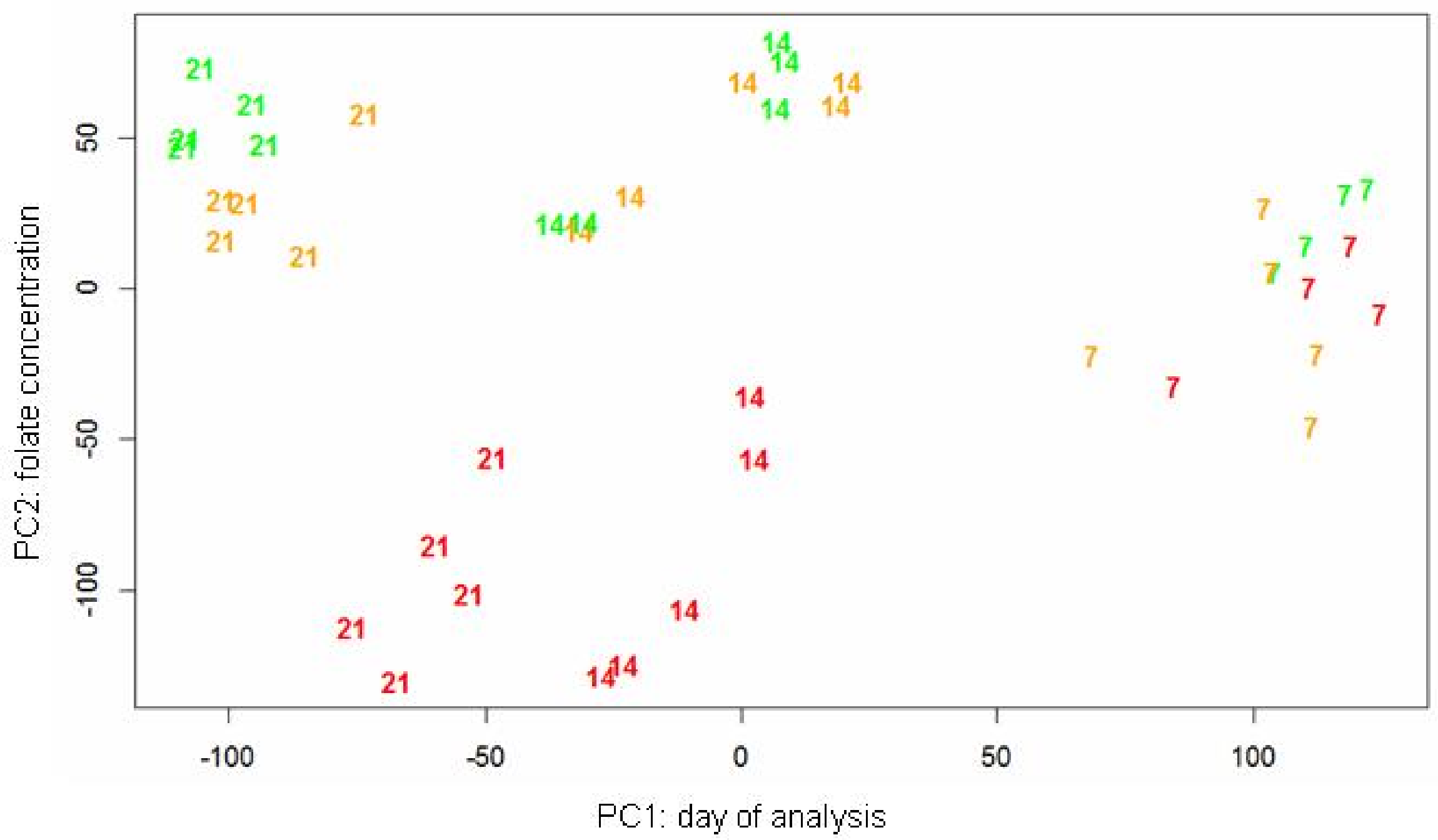



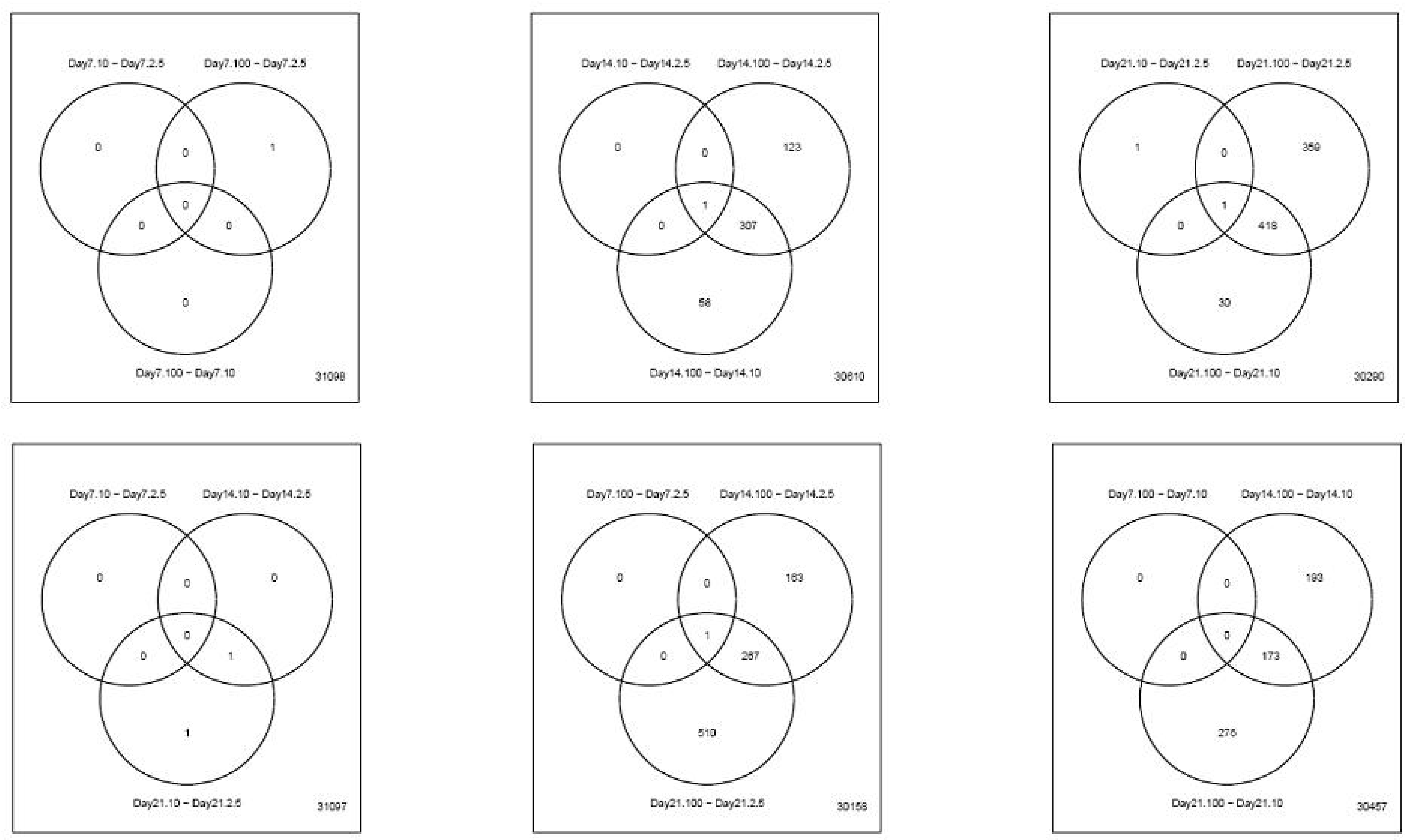
A

thioredoxin interacting protein [TXNIP]

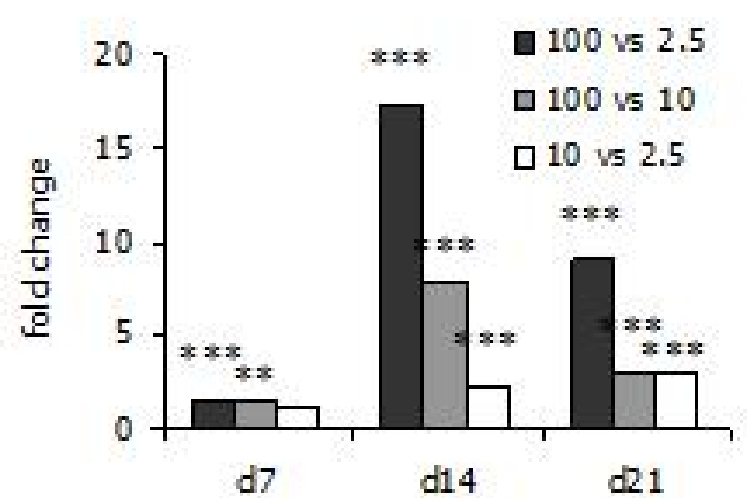

D

prion protein dublet [PRND]

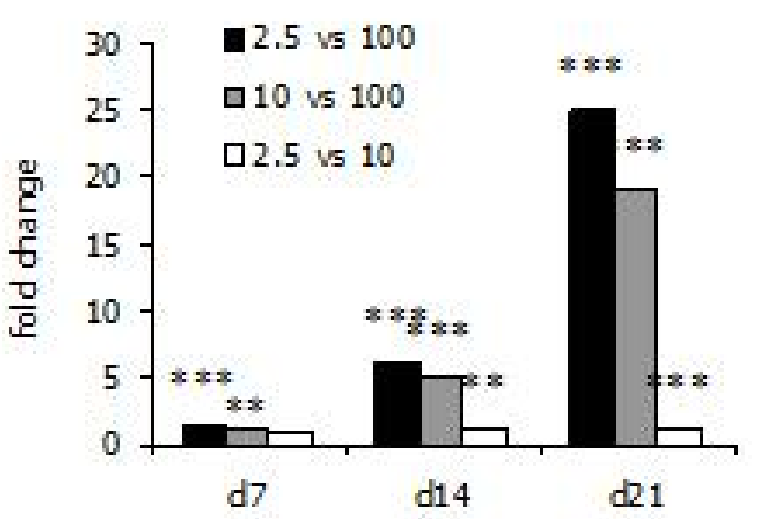

B

insulin induced gene 1 [INSIG1]

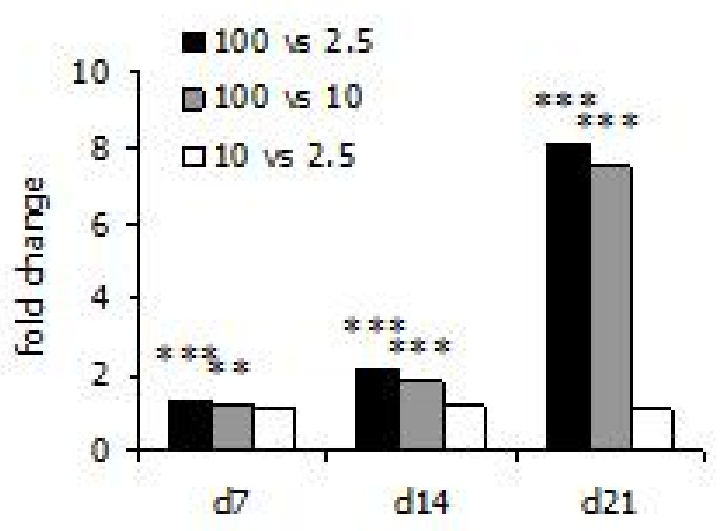

E

myosin heavy chain s km [MYH2]

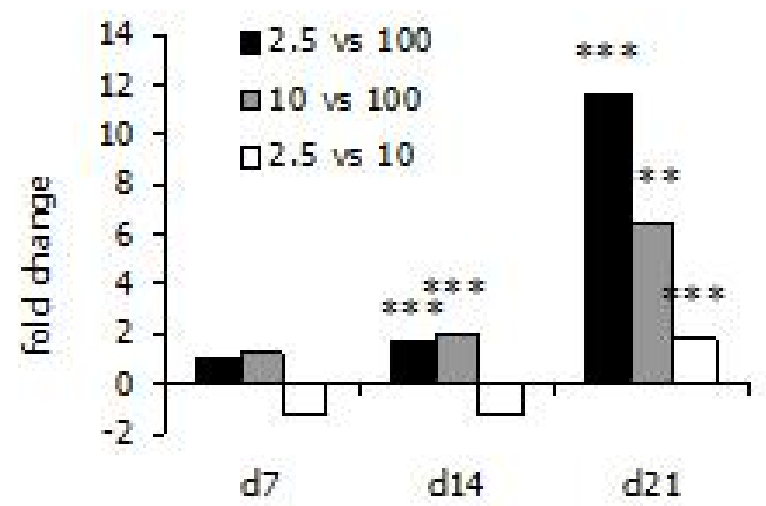

C

iopentenyl diphos phate isomerase [IDI1]

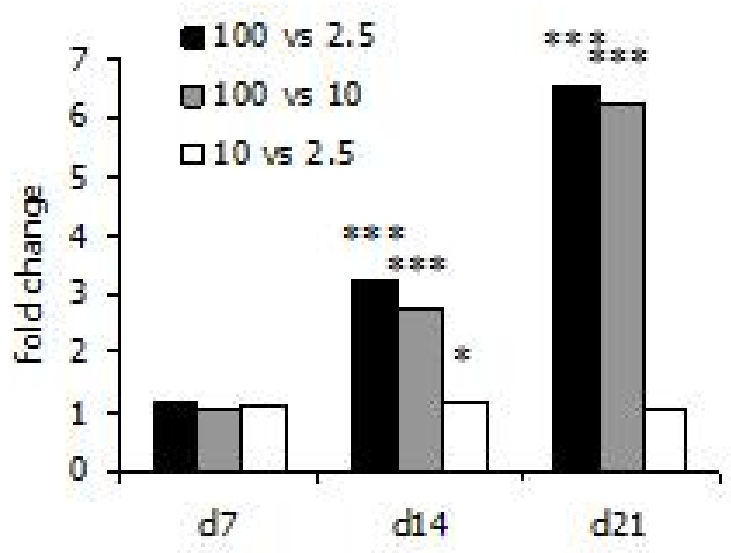

F

a-actin s km [ACTA1]

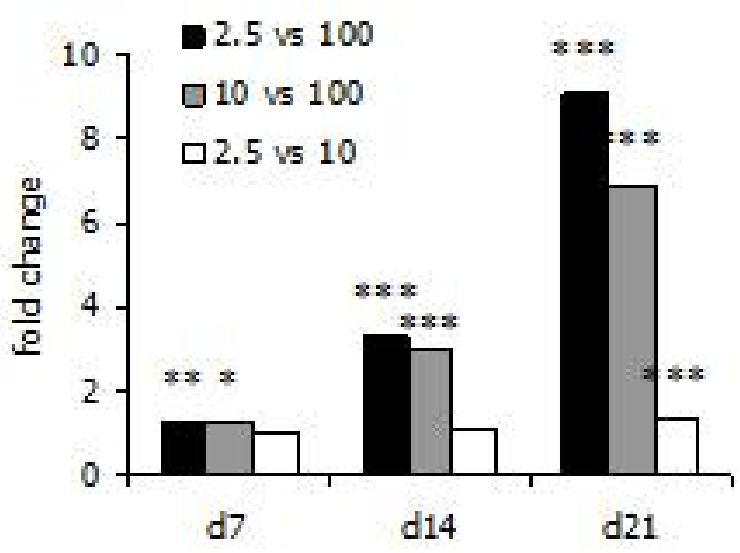


A

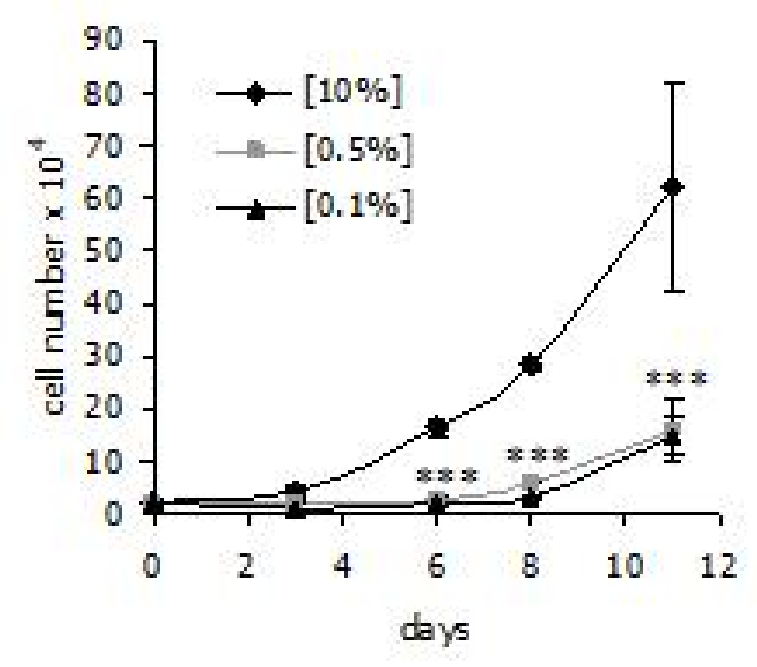

C

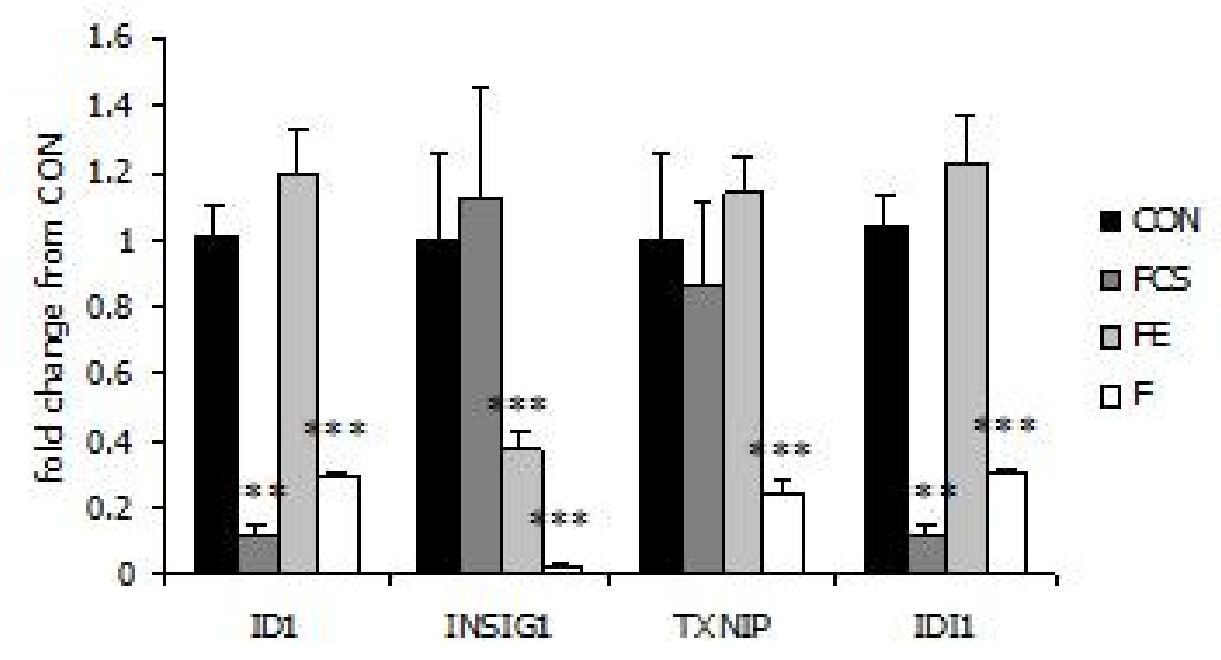

B

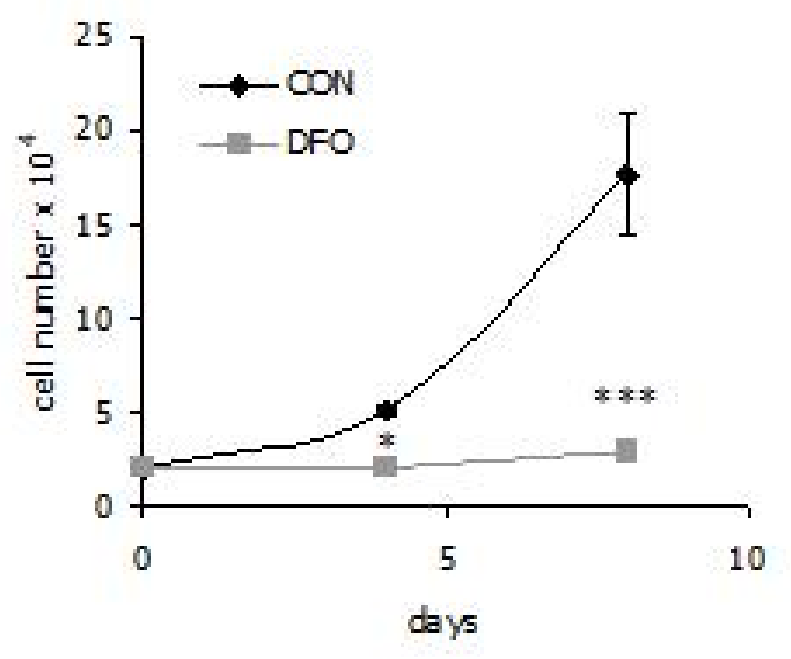

D

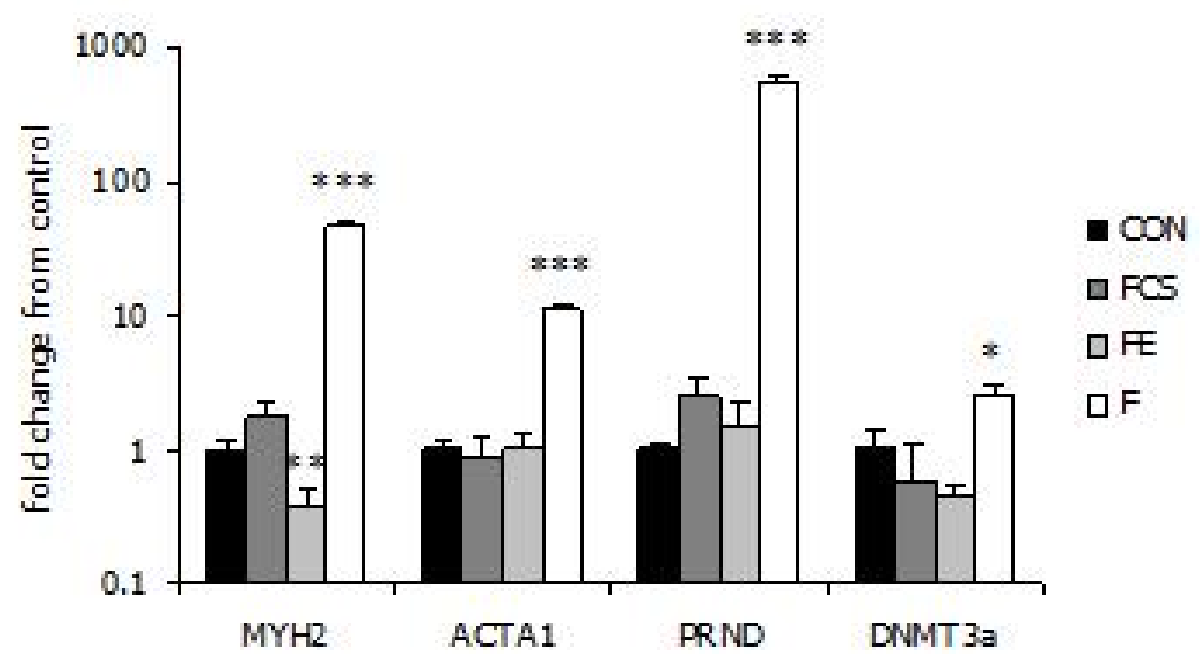



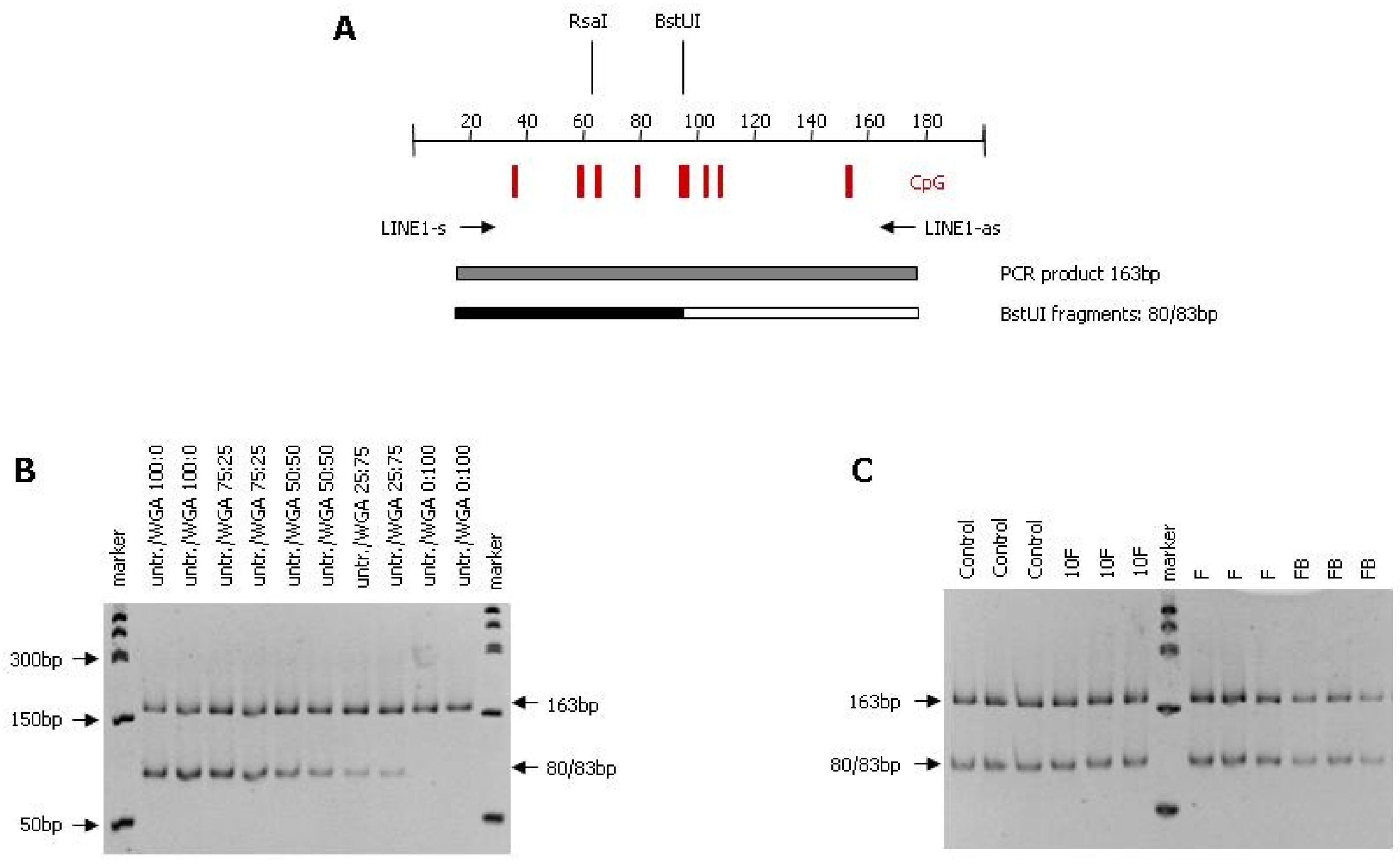

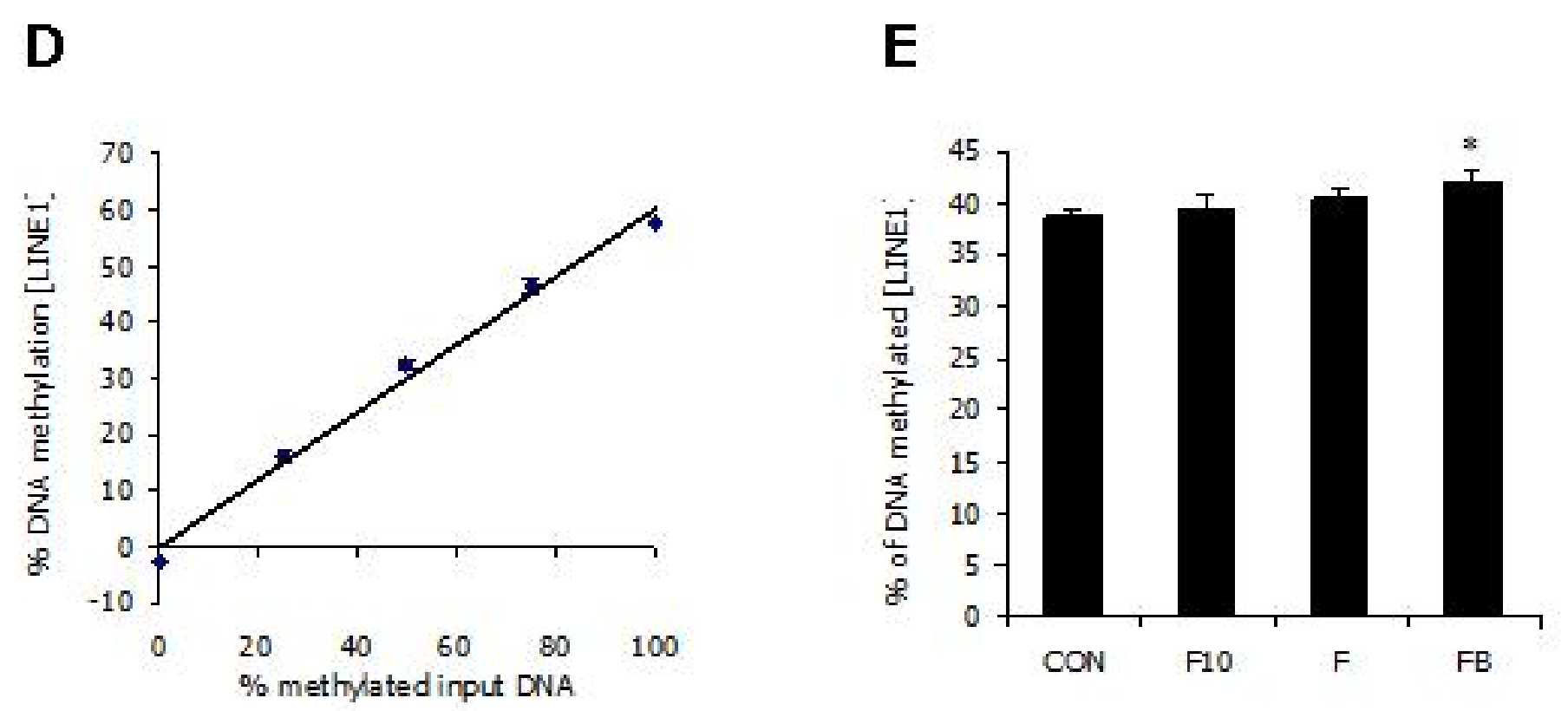

F

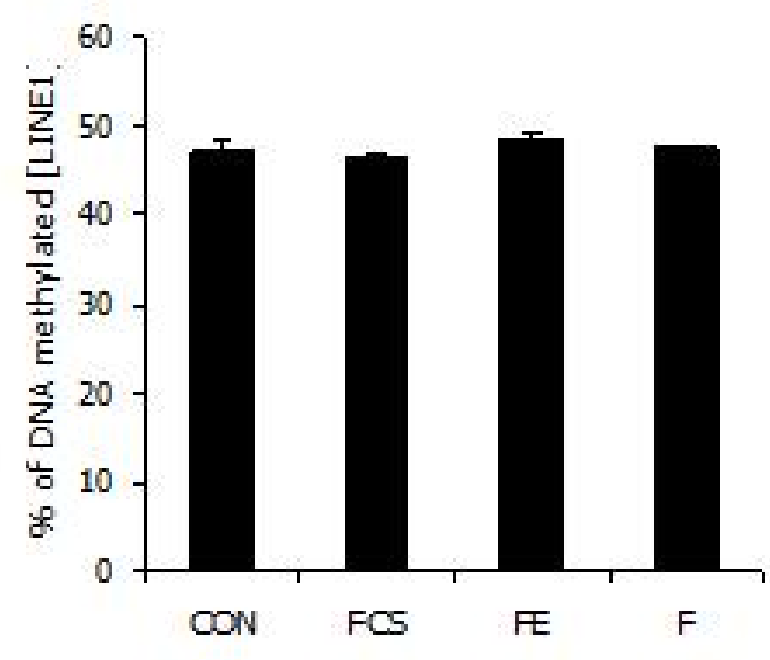


A

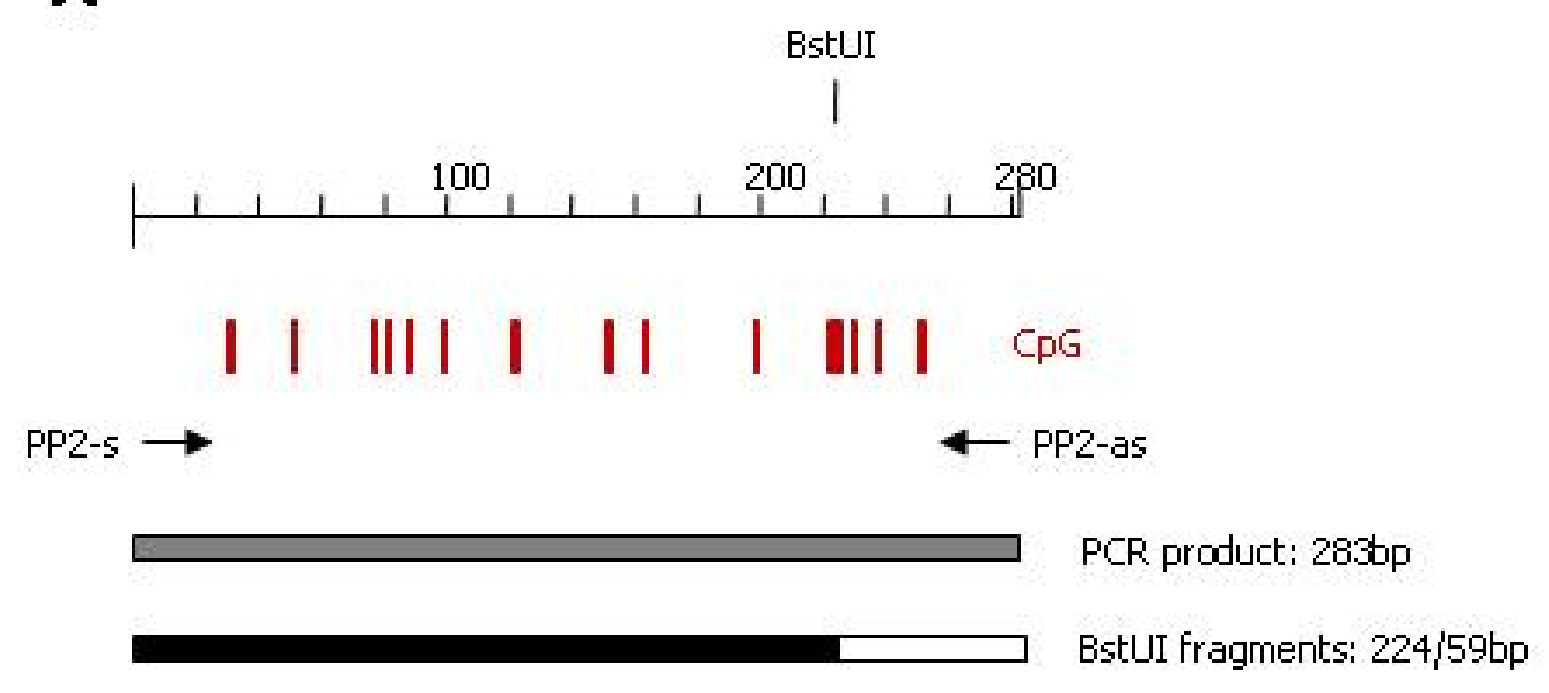

C

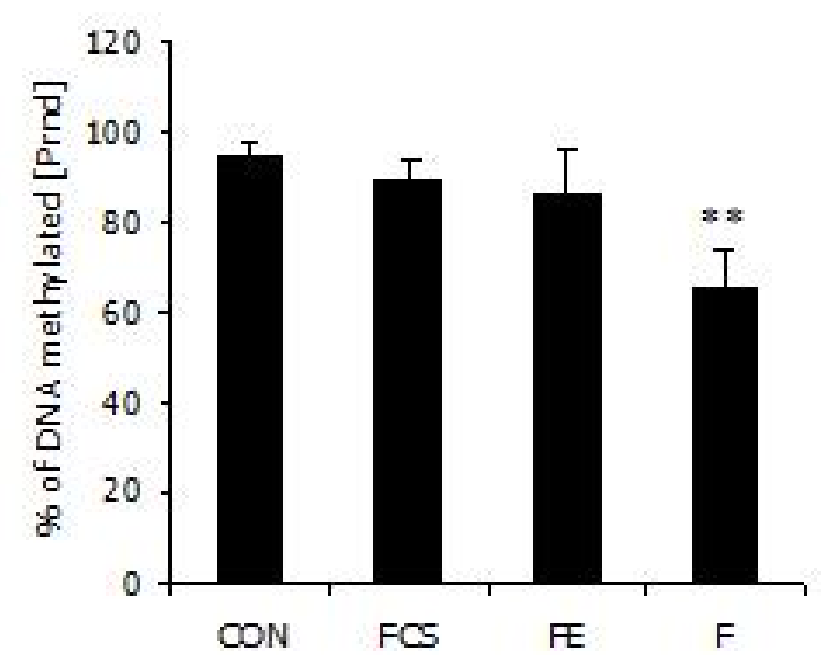

B

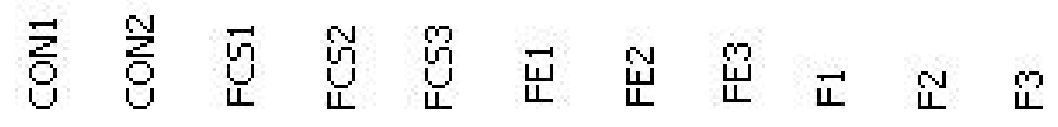

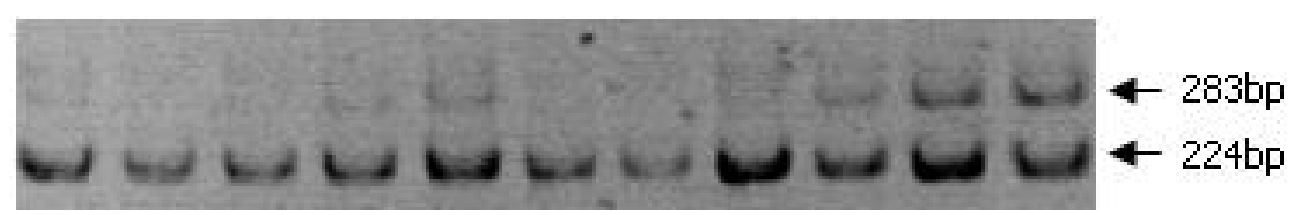


G

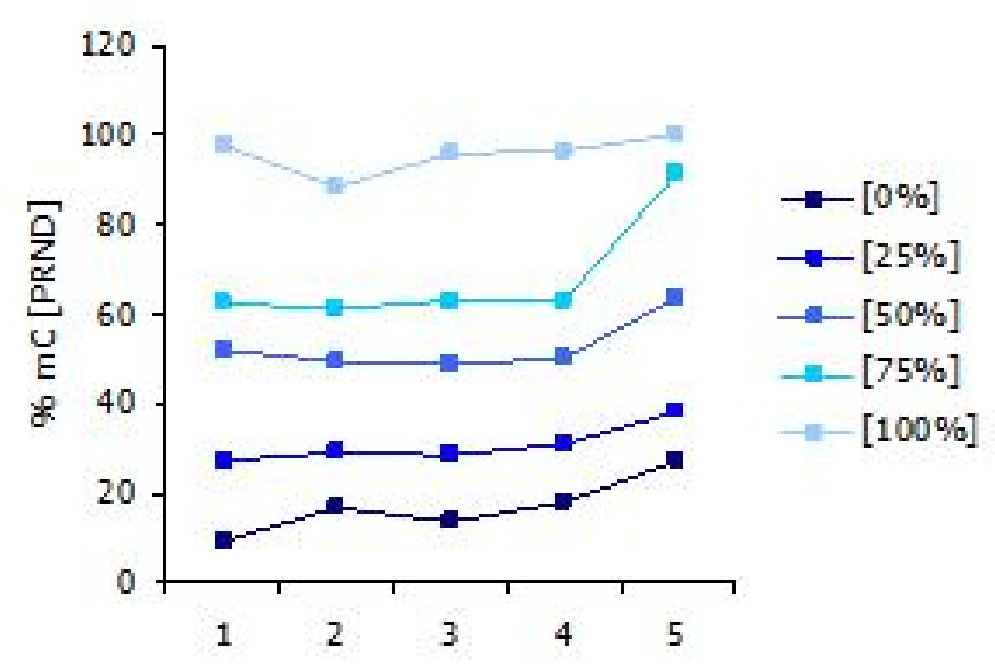

H

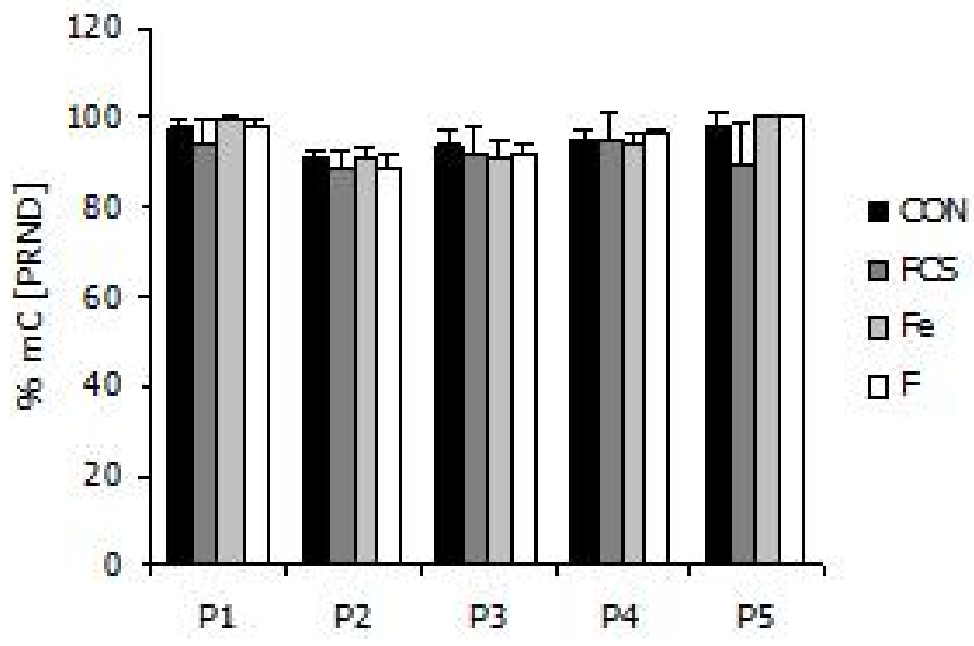


A

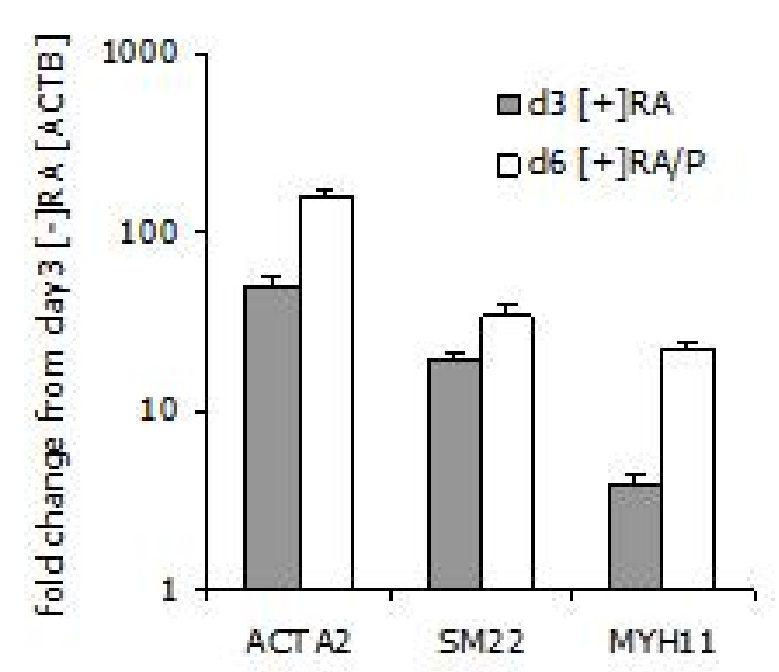

B

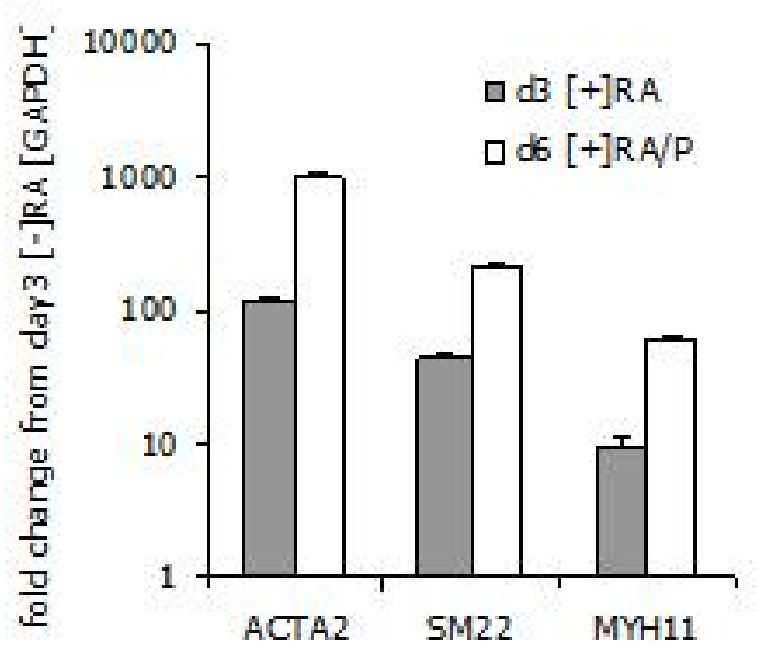

C

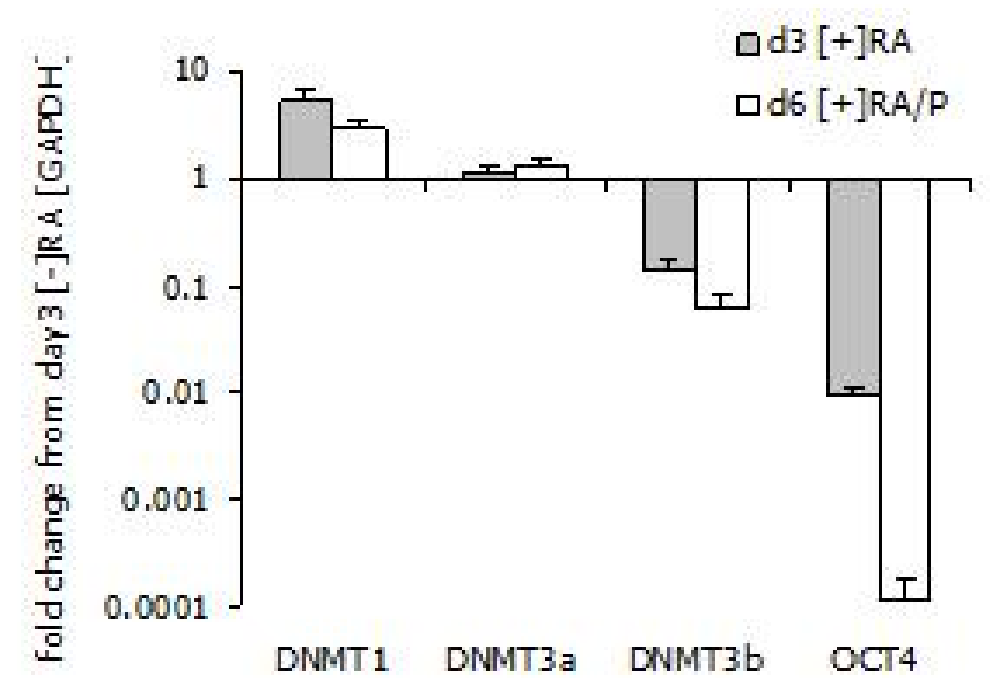

D

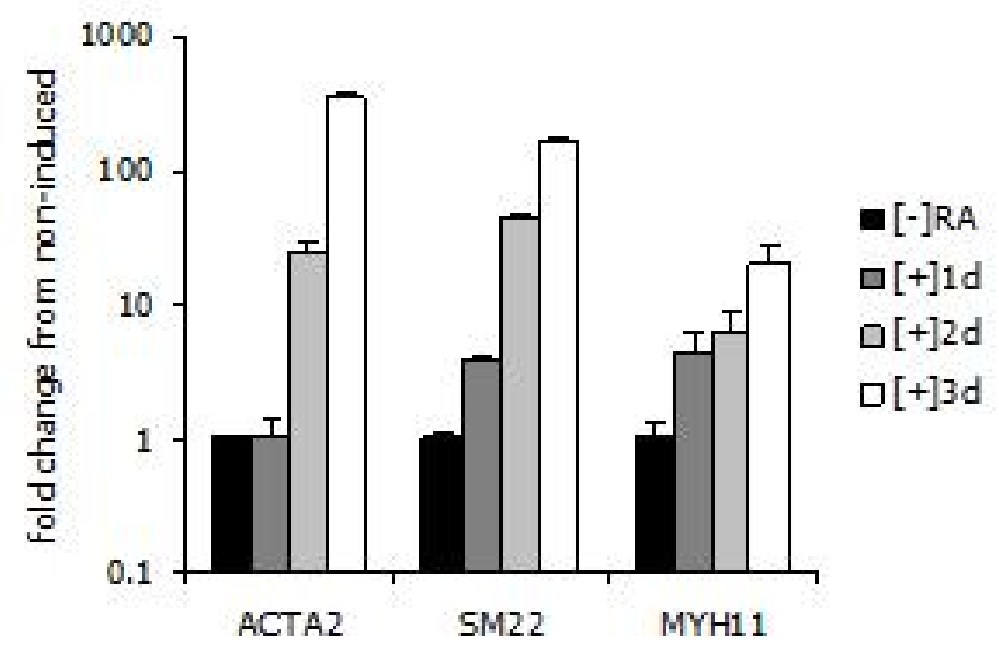


A

ACTA2 - ID 7687

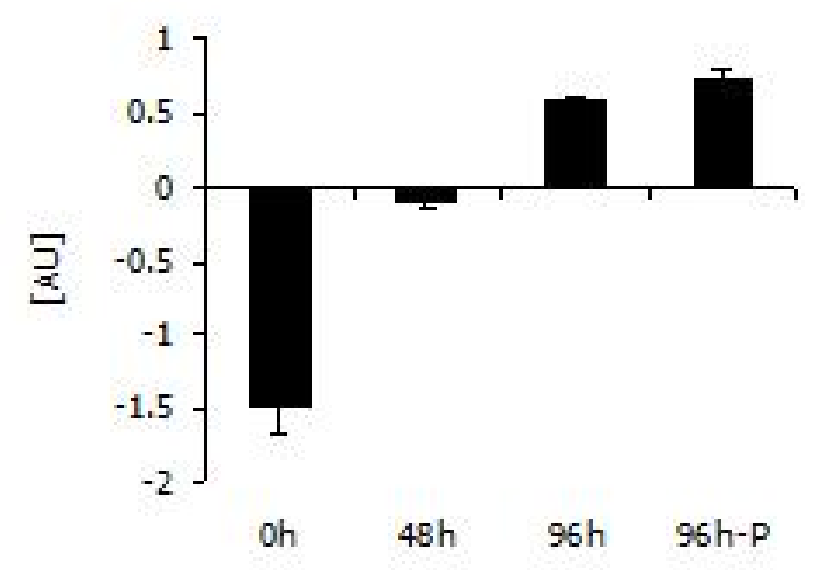

D

Dnmt1 - ID 19991

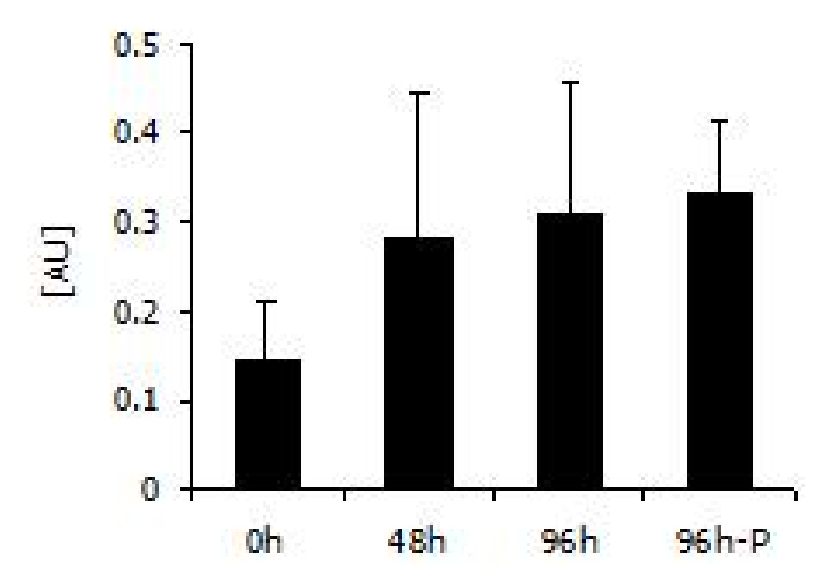

B

SM22 - ID 15803

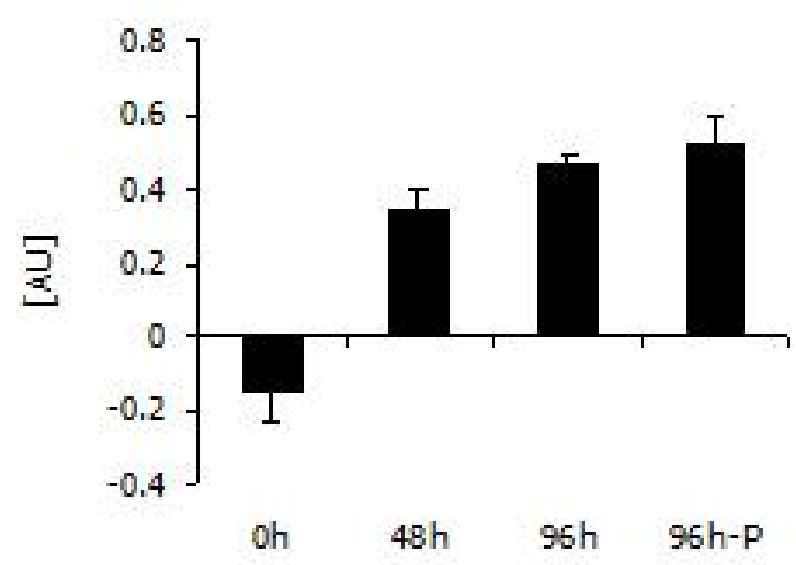

E

Dnmt3a

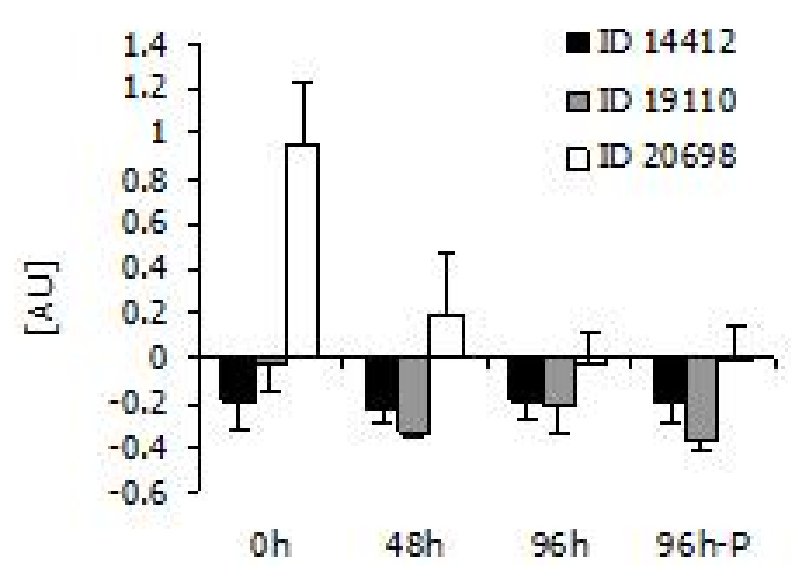

C

Oct4 - ID 5193

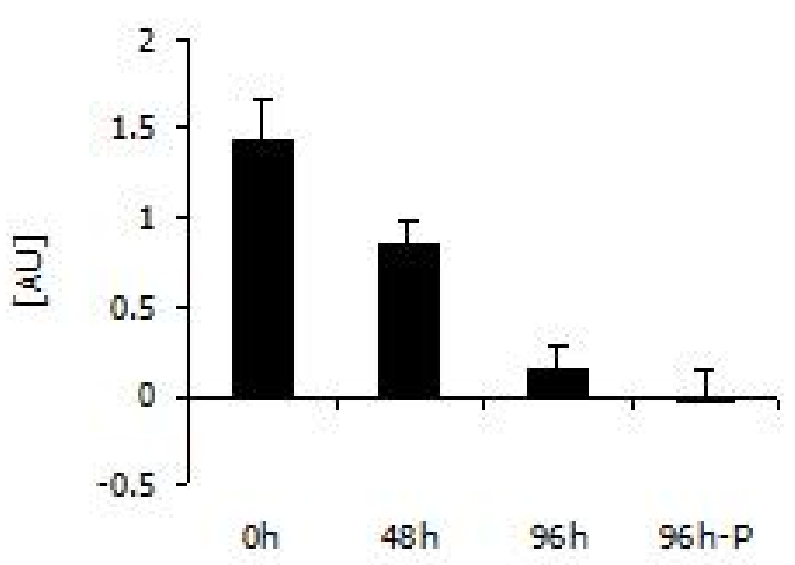

F

Dnmt3b - ID 14143

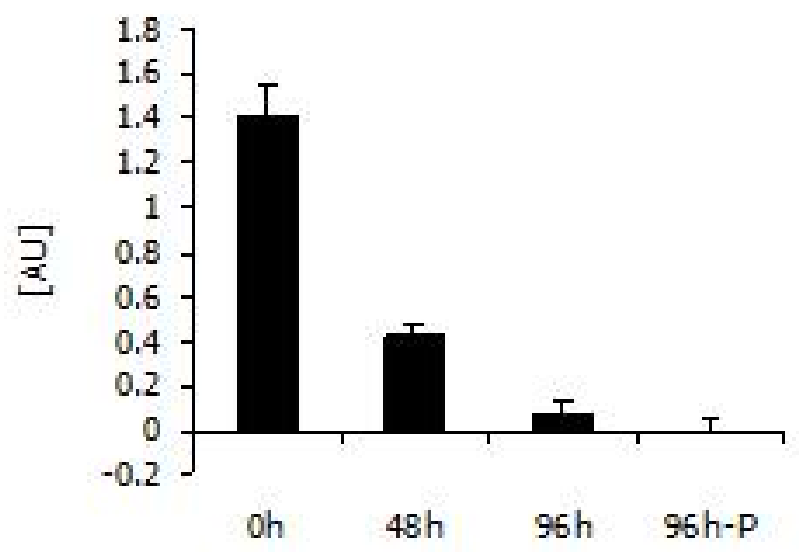


A

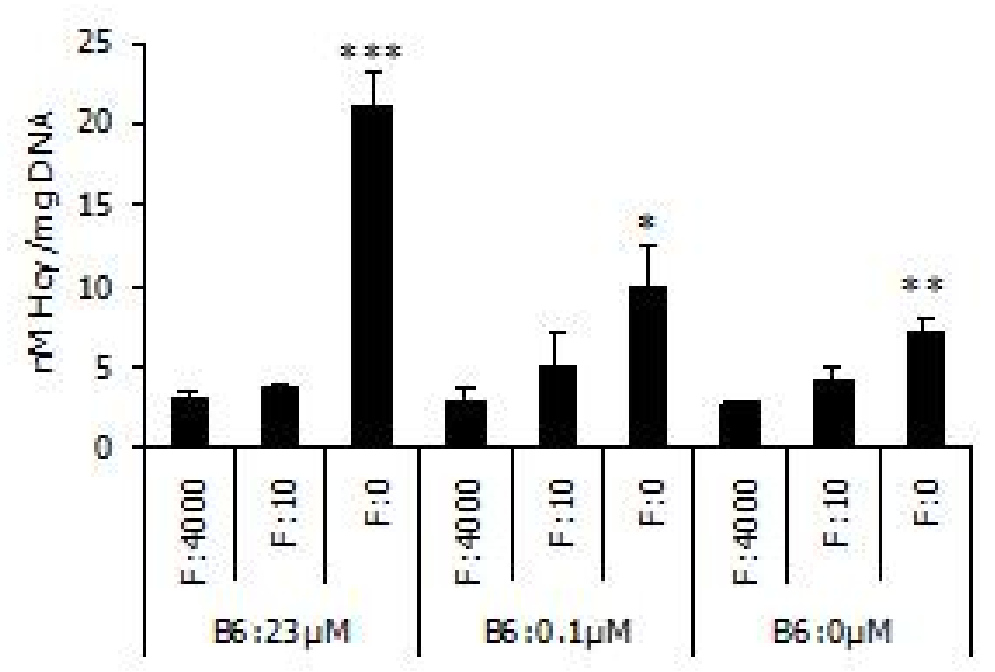

B

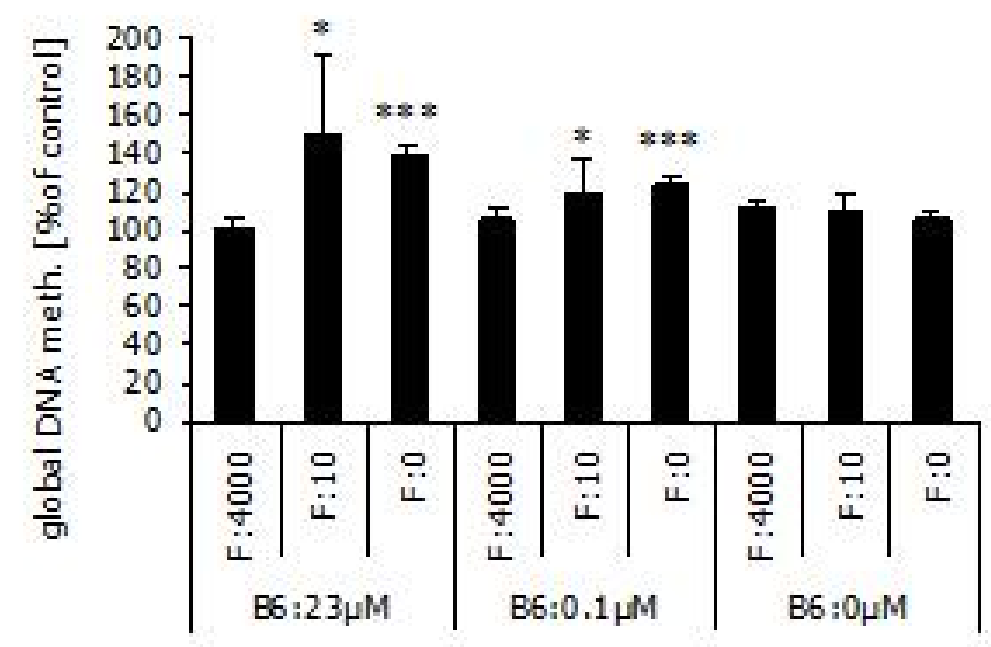


A

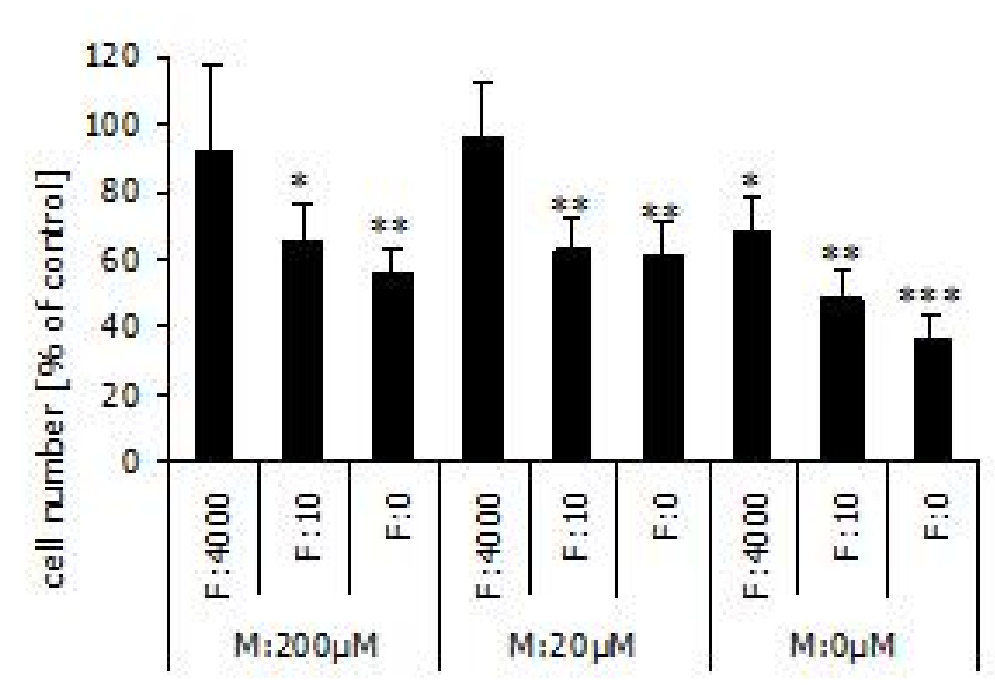

C

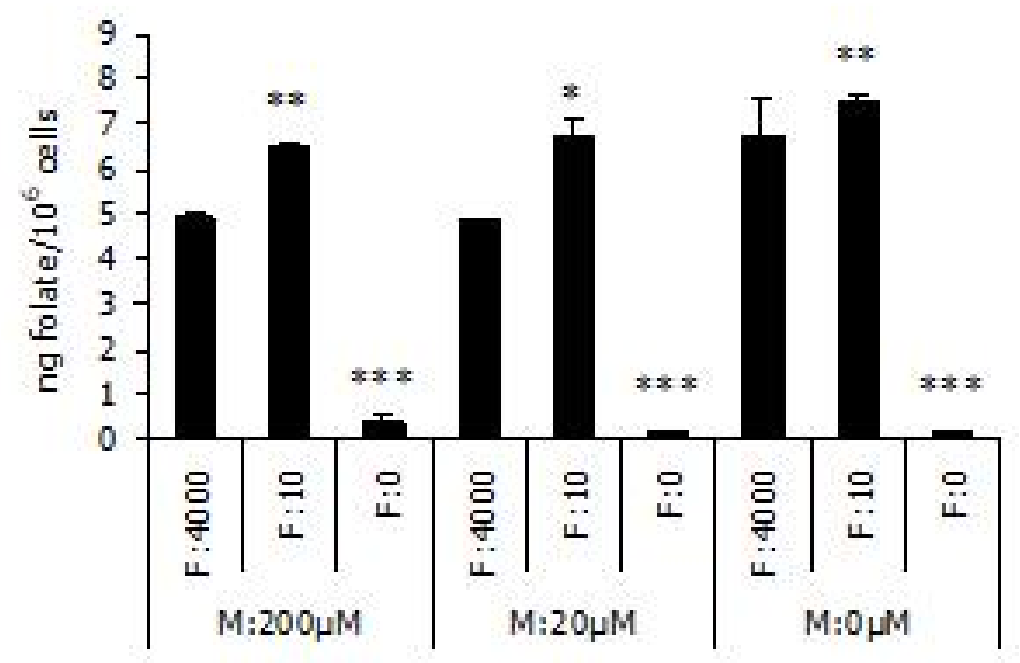

B

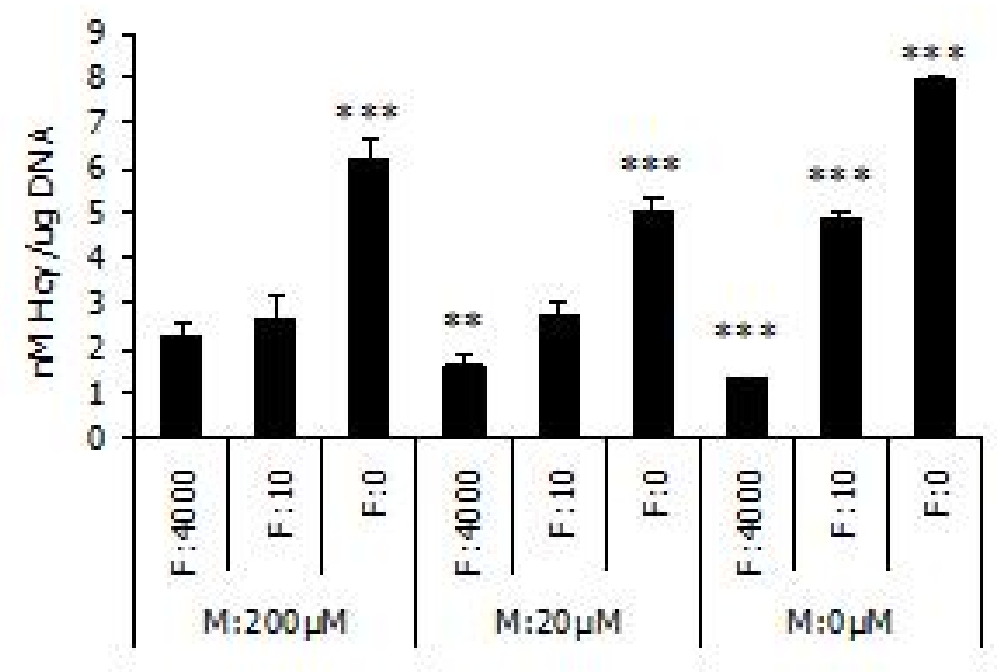

D

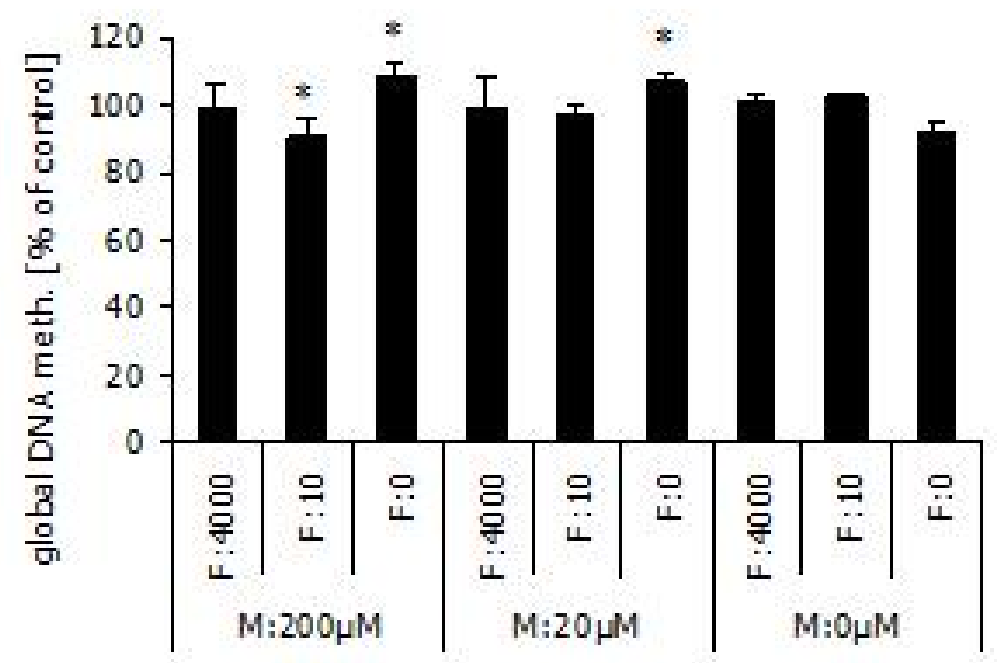

E

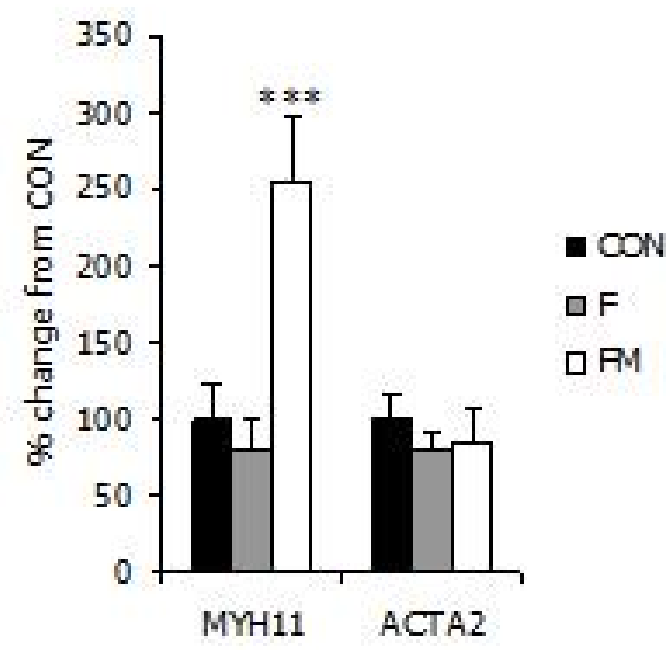


[-] F gene list [p<0.01; fold change $>2]$

genes activated by folate deficiency

A

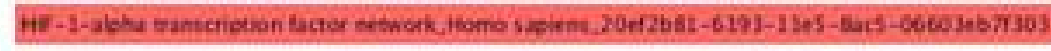

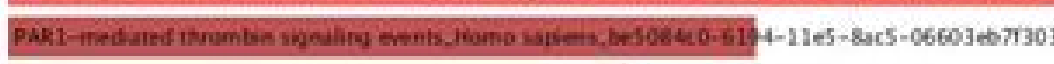

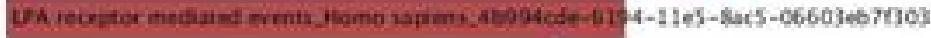

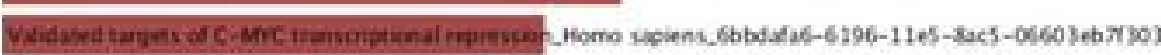

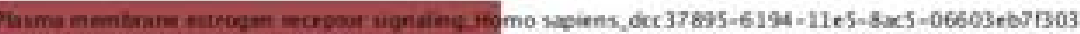

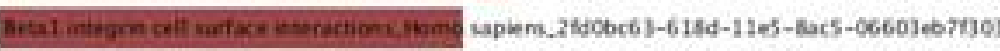

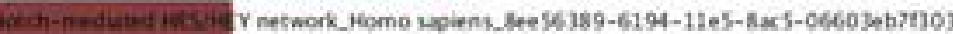

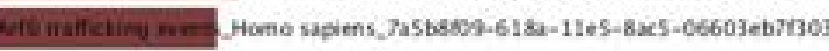

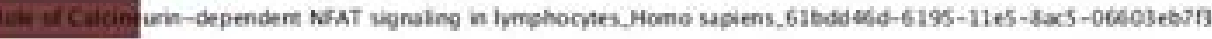

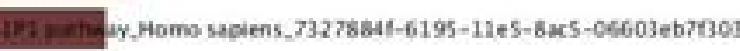

NCI-Nature 2016

B

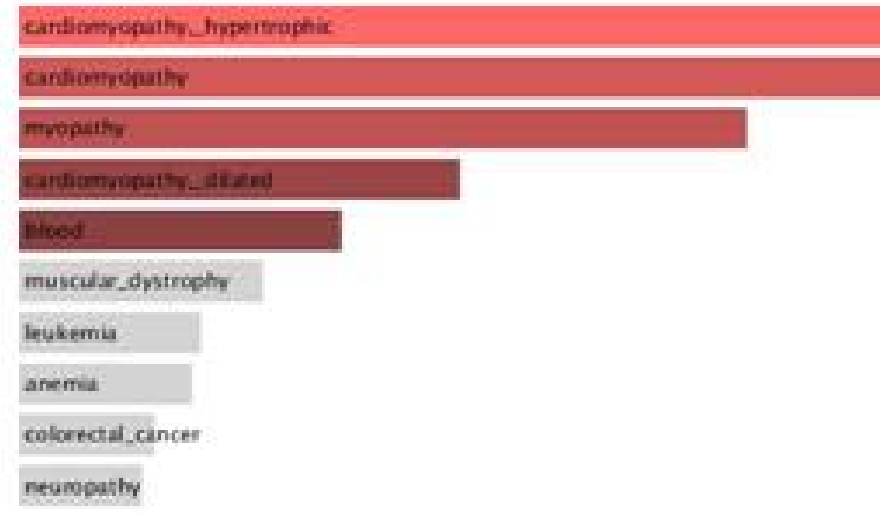

OMIM disease

C

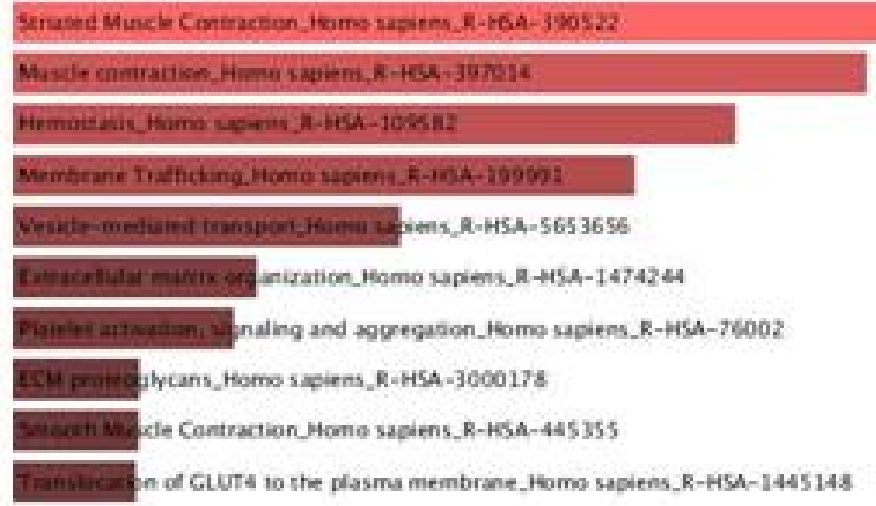

Reactome 2016
[+] F gene list [ $<<0.01$; fold change $>2$ ] genes silenced by folate deficiency

D

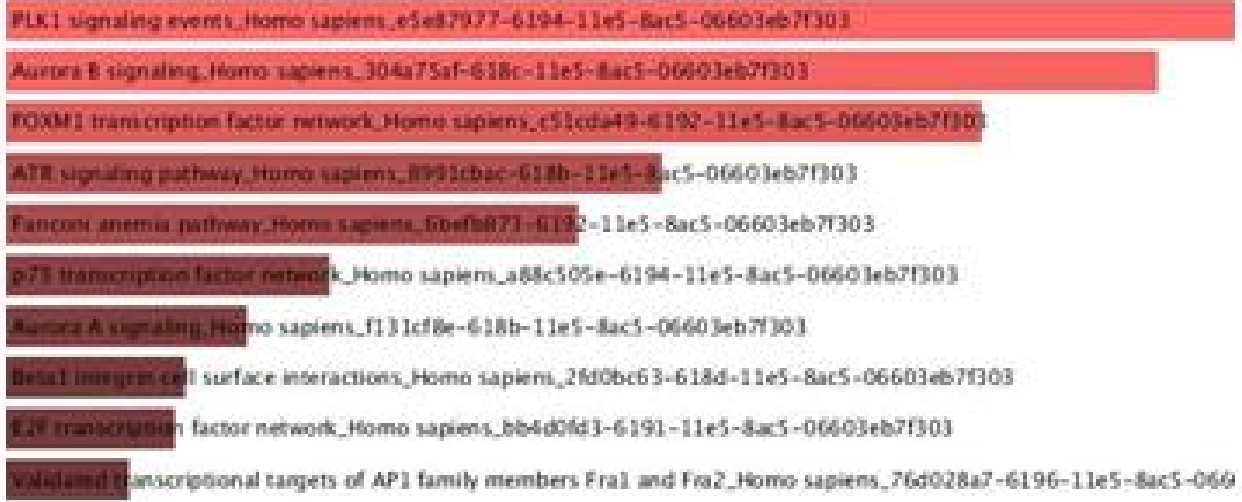

NCI-Nature 2016

$\mathbf{E}$

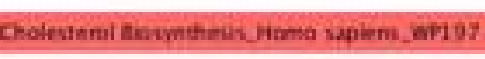

Cer Cycle, , womo sapiem, WP179

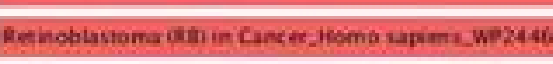

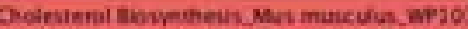

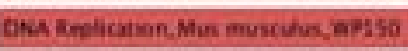

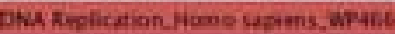

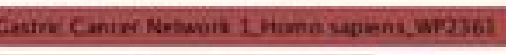

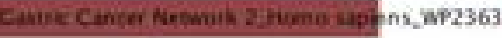

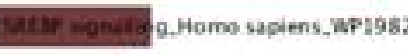

cycie control.,Homo sapiens. Wpes

WikiPathways 2016

$\mathbf{F}$

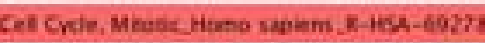

Cet Cyde, hama warens, K-HSA-1640170

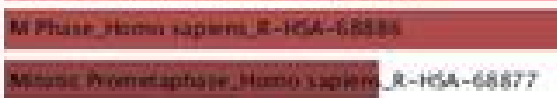

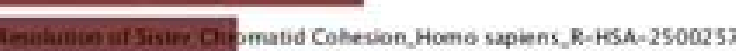

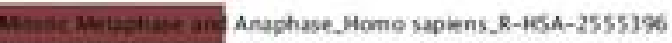

Ter Chromatidi.Homo sapiens, R-H6A-2467s

ave.Homo sapiens, $k$-HSA-6s8:

heckooins Homo sapiens_ $R-16 A-69620$

mo sabiens_R-HSA-9s318:

Reactome 2016 
A

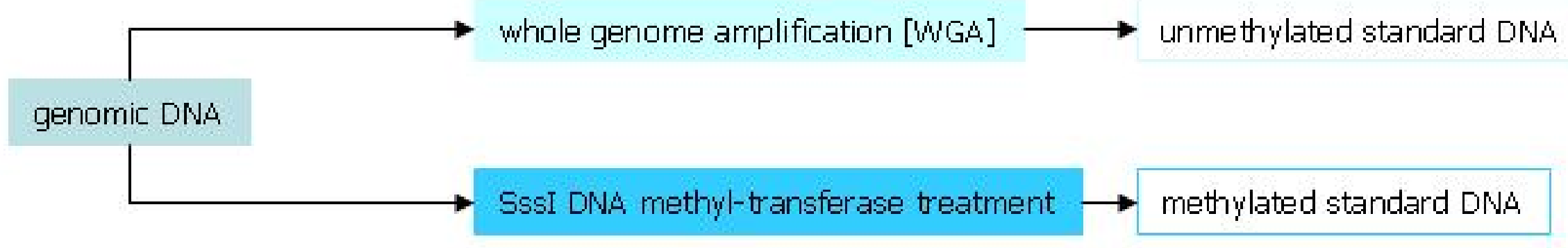

B

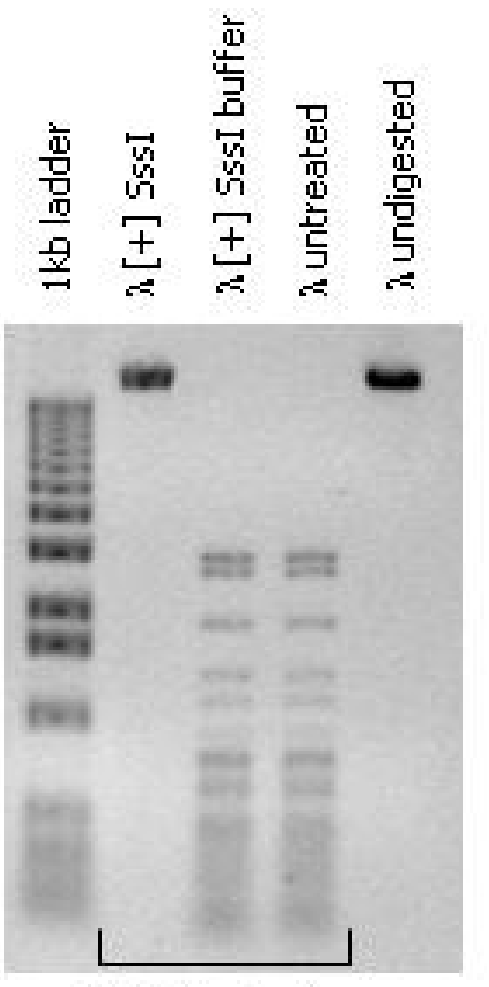

BstuI digested
C

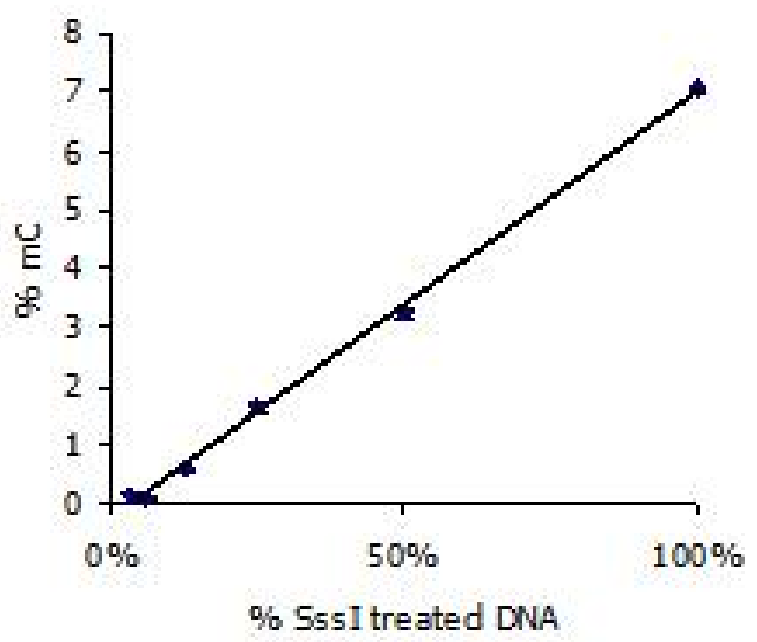

D

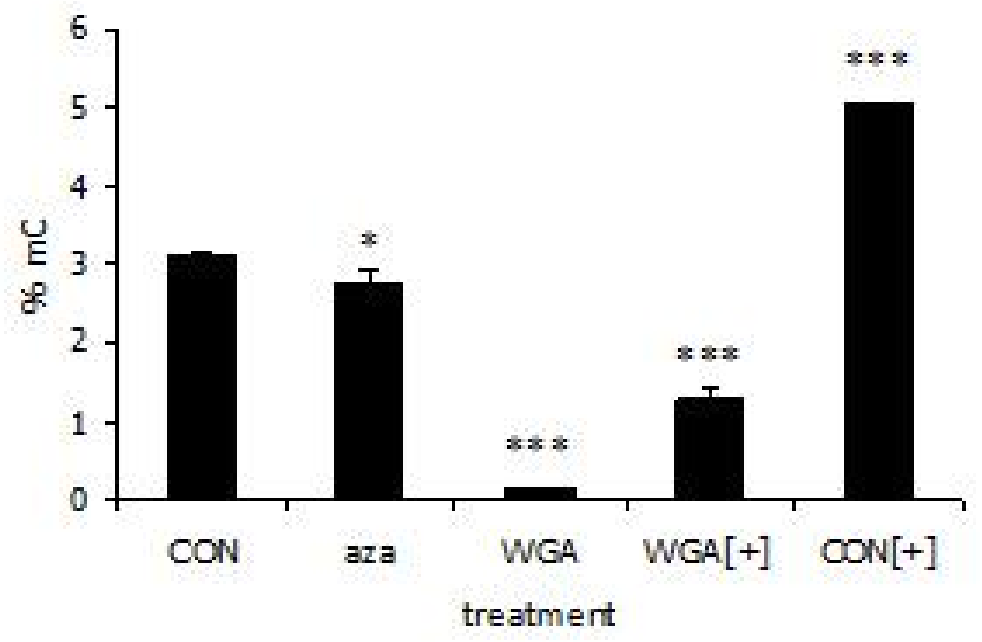


A

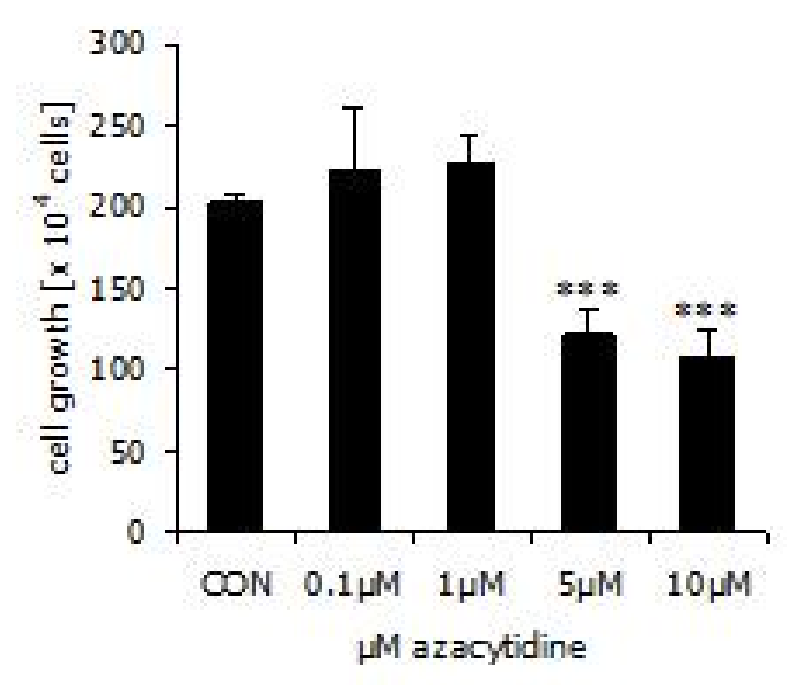

B

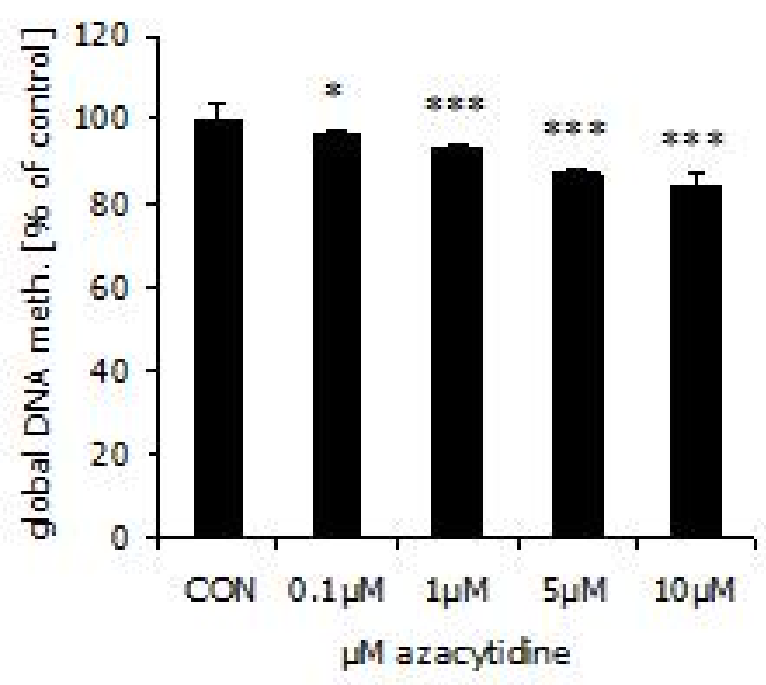


A

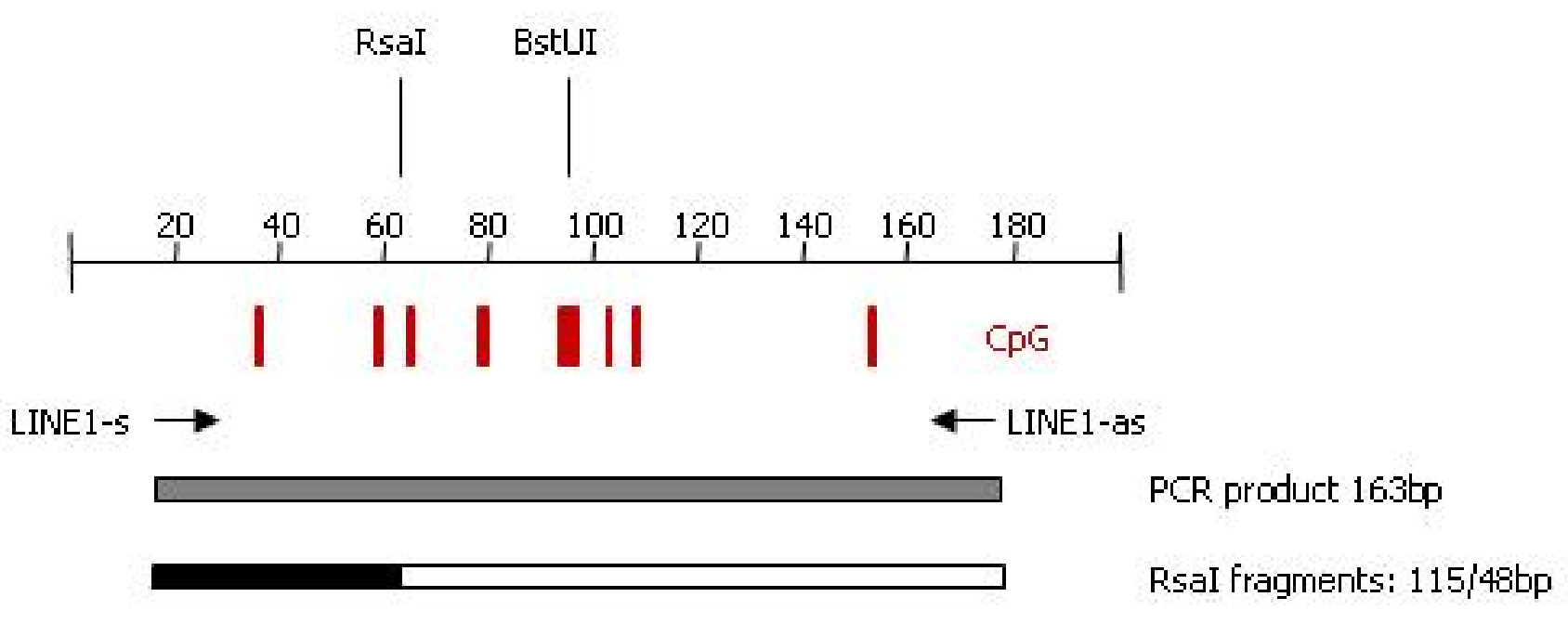

C

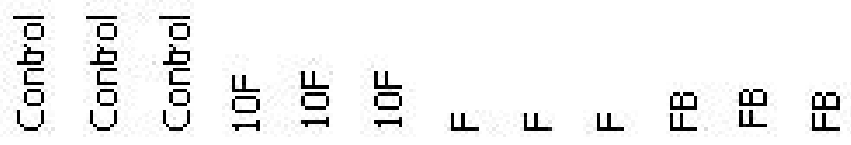

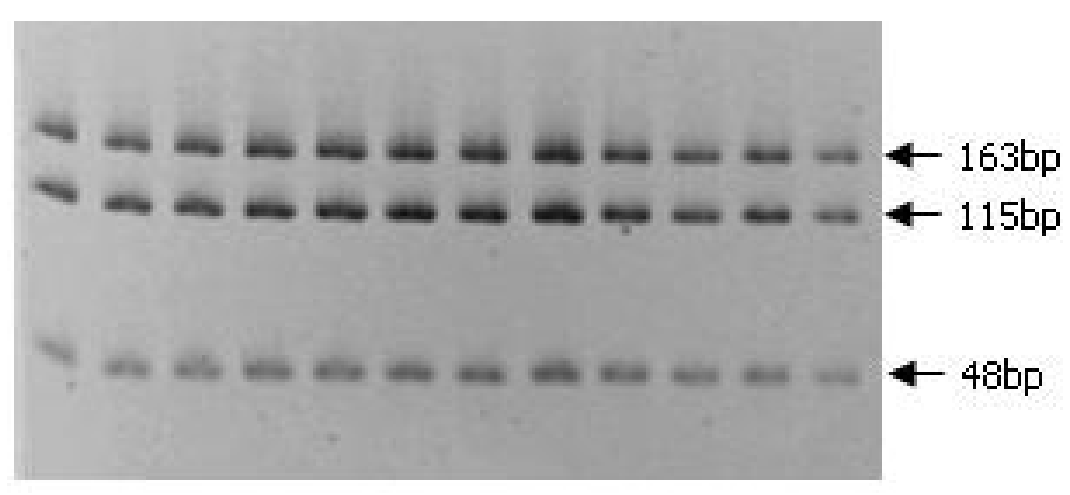

B

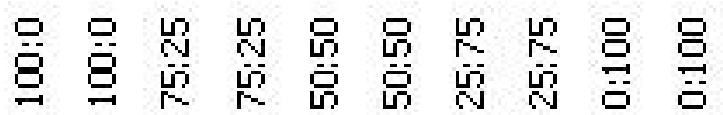

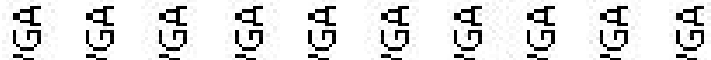

$\geq 2 \geq 2 \geq 2 \geq 2$

站站站站站站站站站站

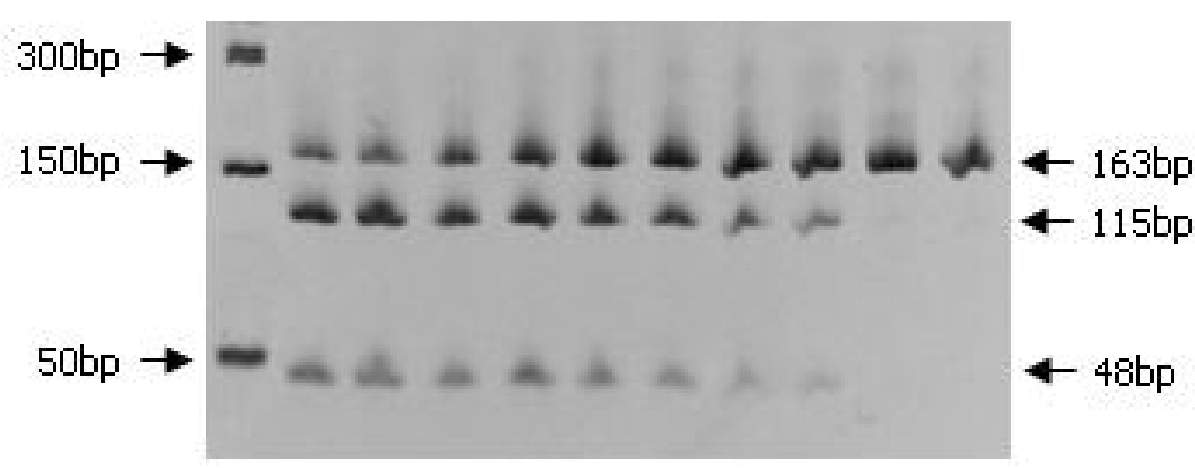

D

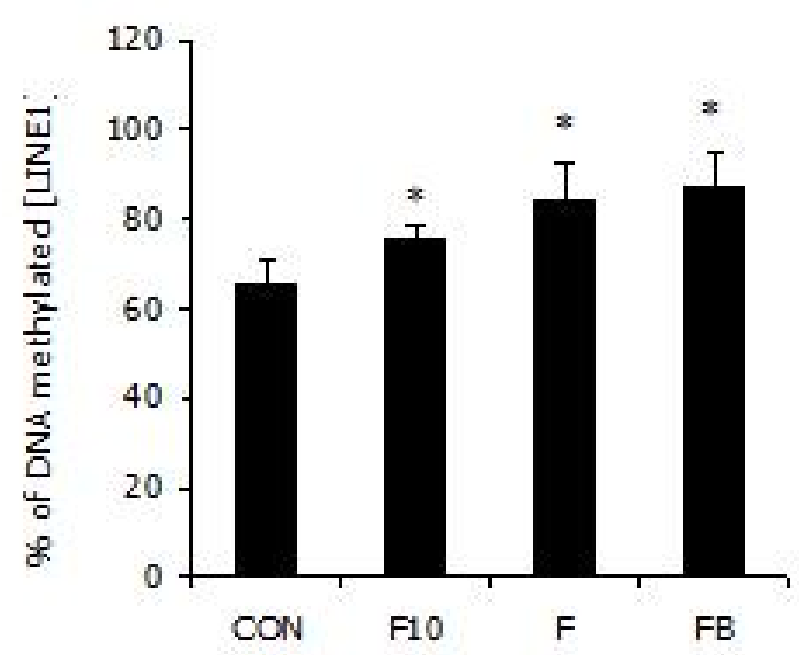


A

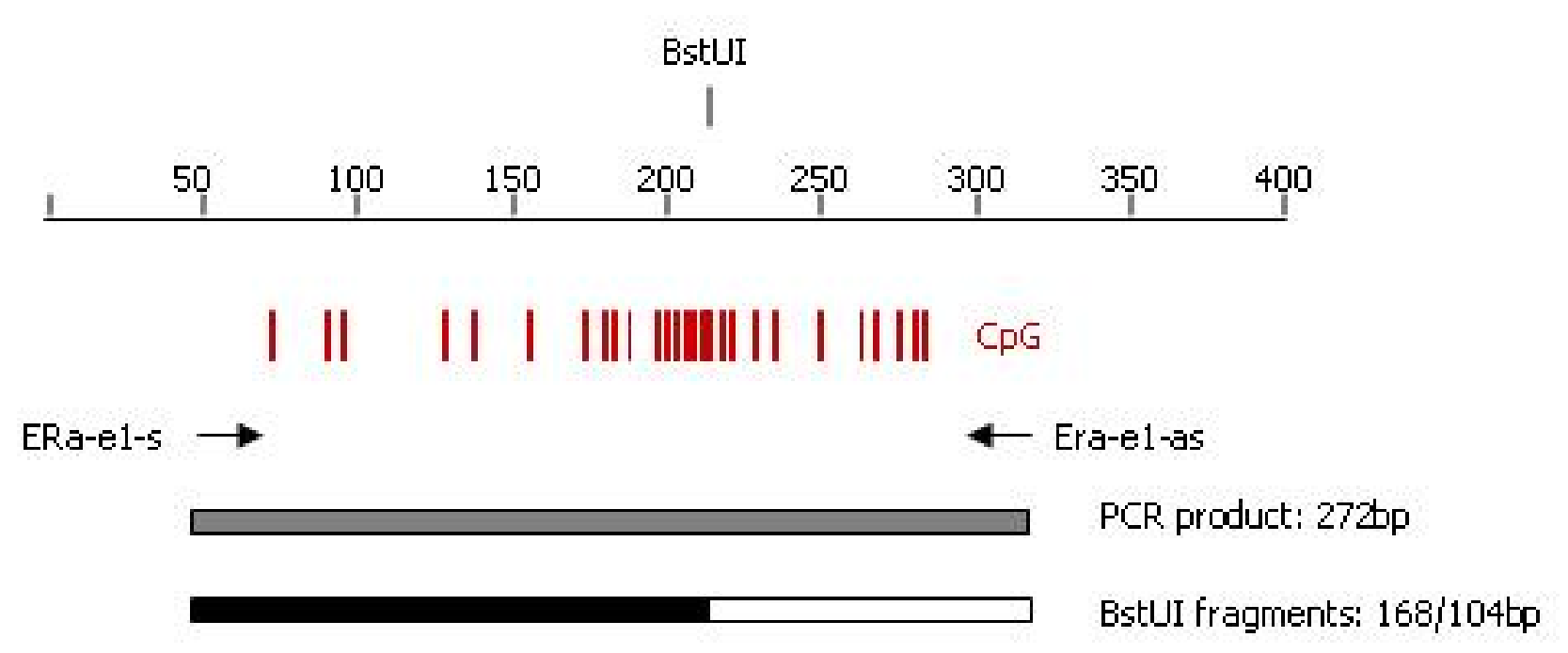

C

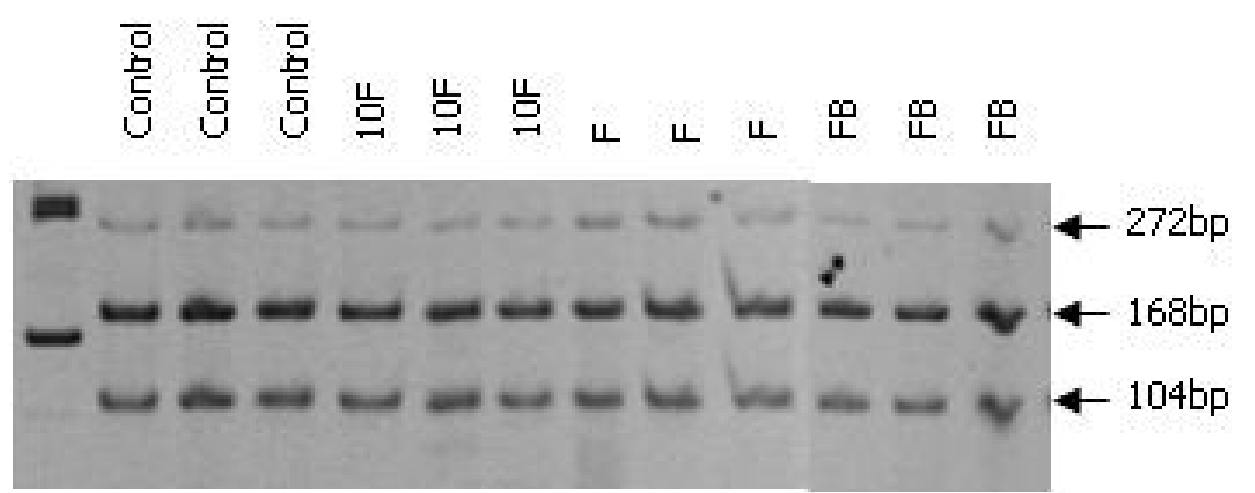

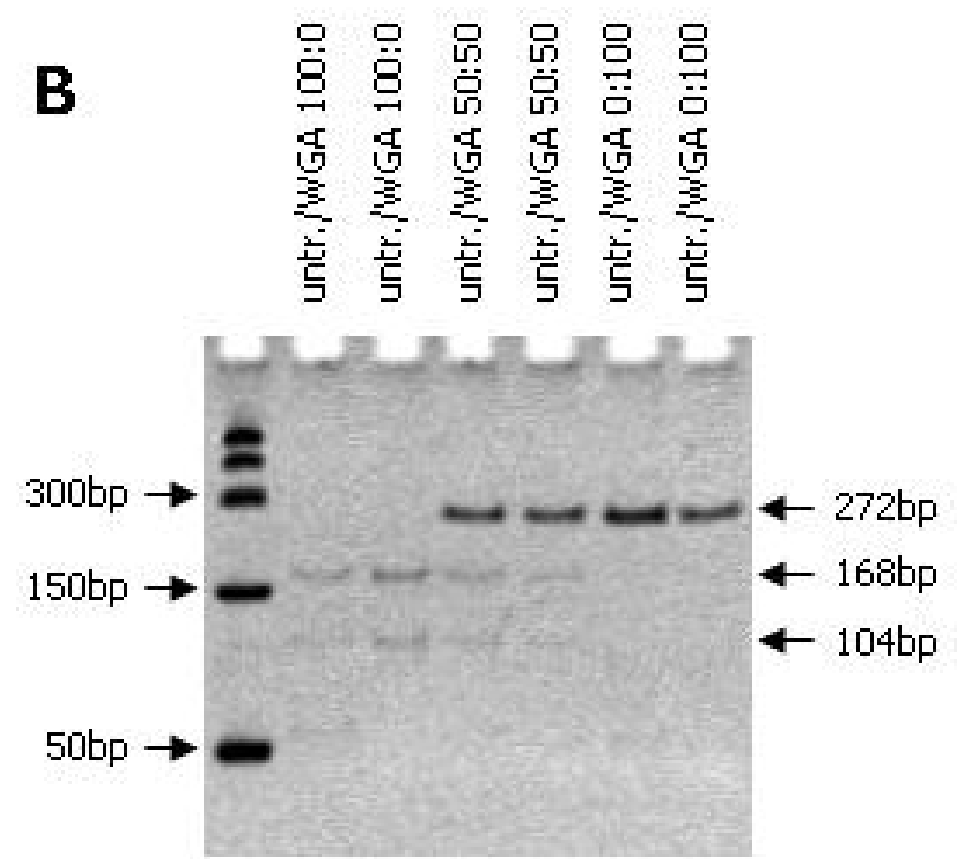

ER- $\alpha$ exon 1

D

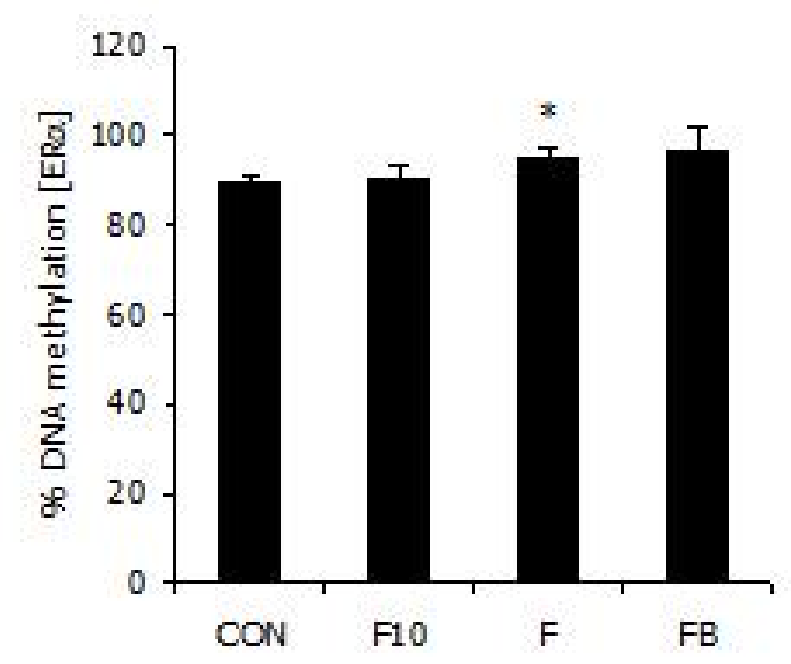


A

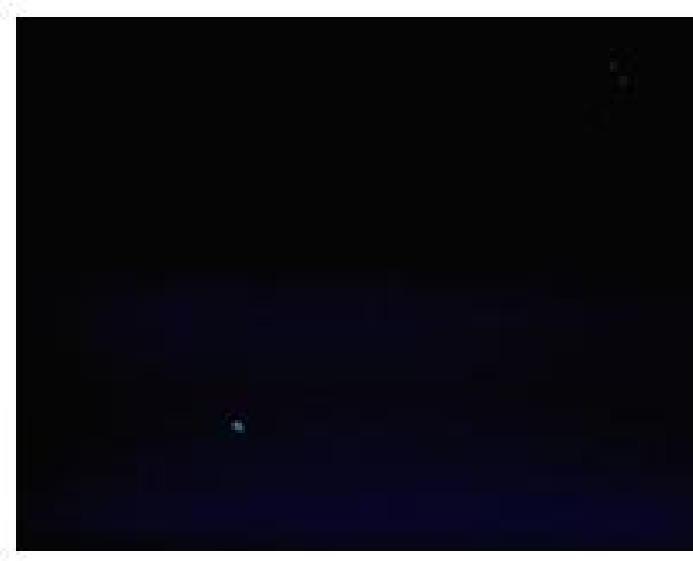

nuclear GFP [A404 cells]
B

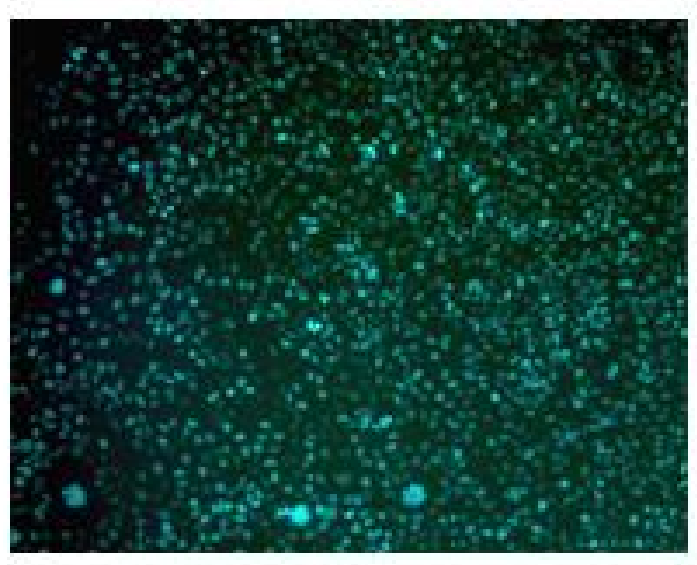

nuclear GFP [HEK293 cells]
C

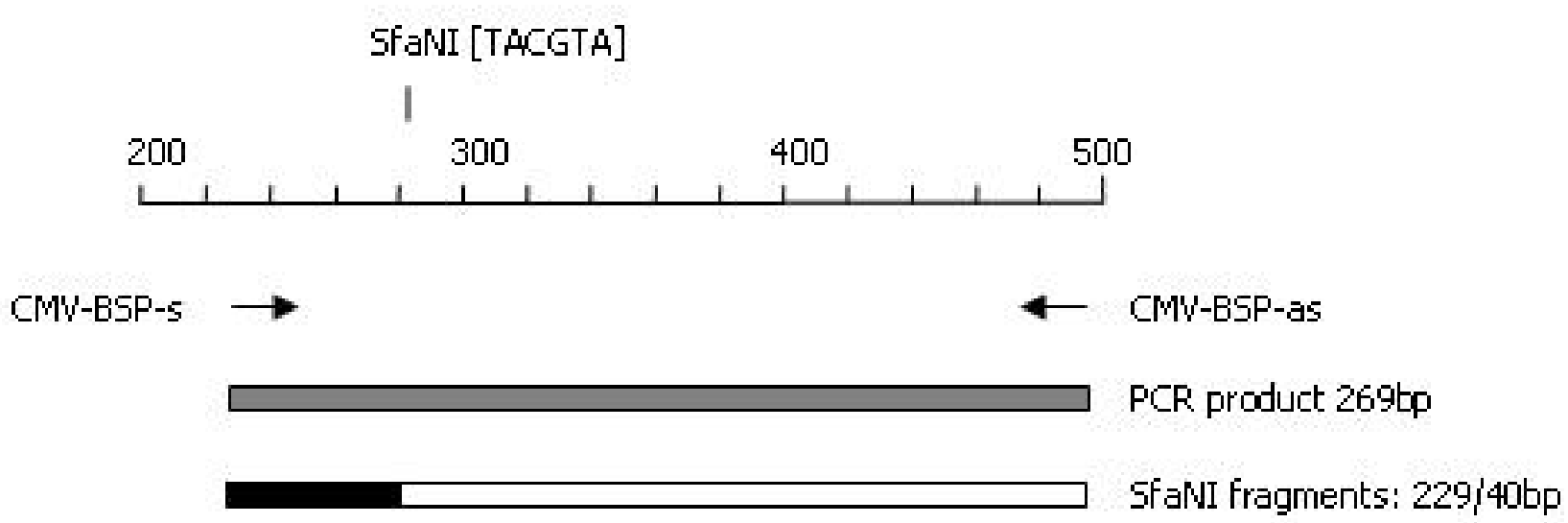

E

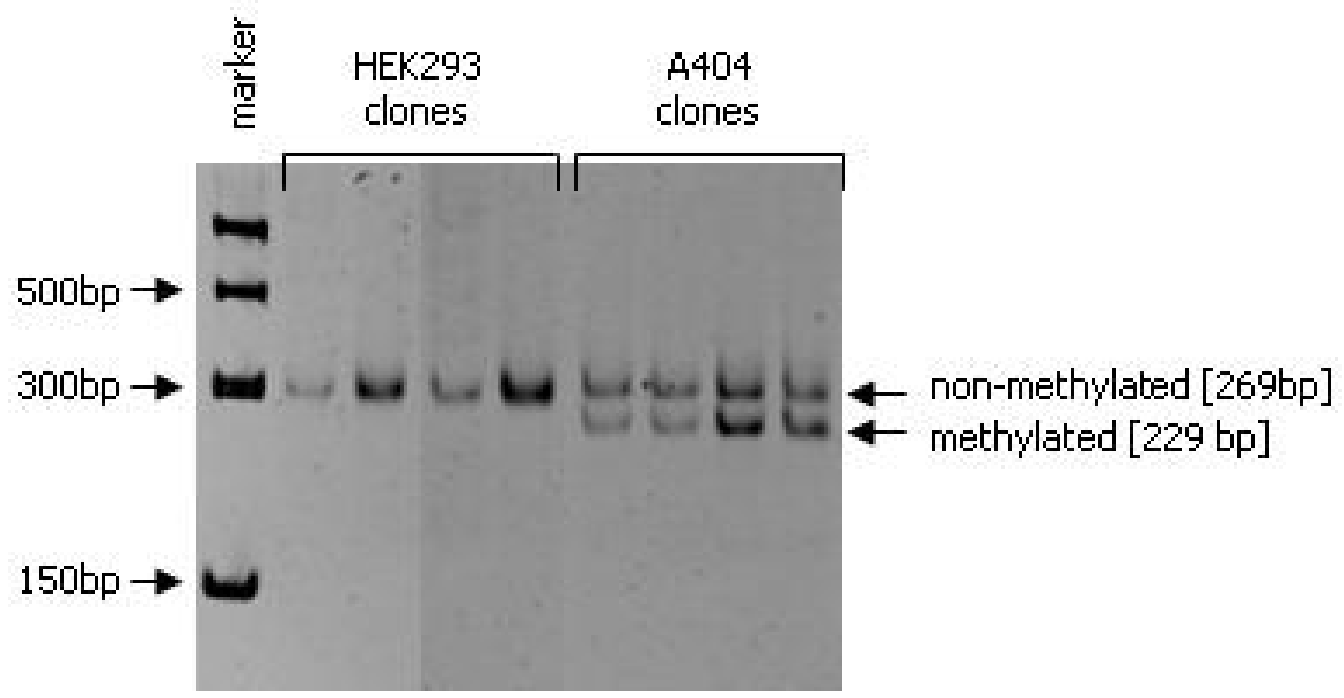


Kolb et al.; Supplementary Fig. 11

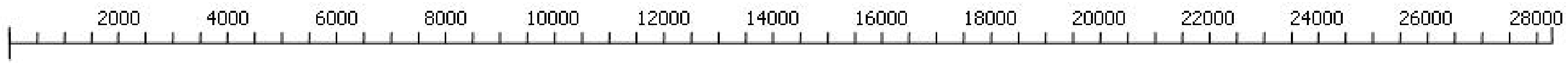

Myh2 mRNA
Myhr $\mathrm{CDS}$

\begin{tabular}{ll|}
\hline ACTA IMRNA \\
ACTA1 CDS \\
CPG island \\
Pyrosequencing
\end{tabular}

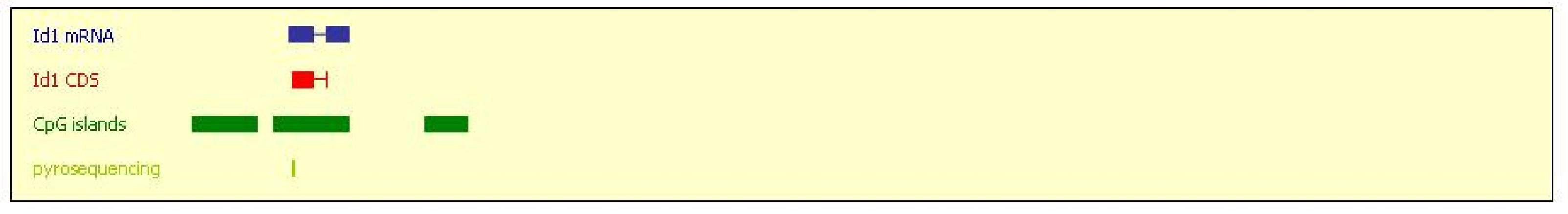

Prnd mRNA
Prnd CDS
CpGisland
Pyrosequencing
COBRA



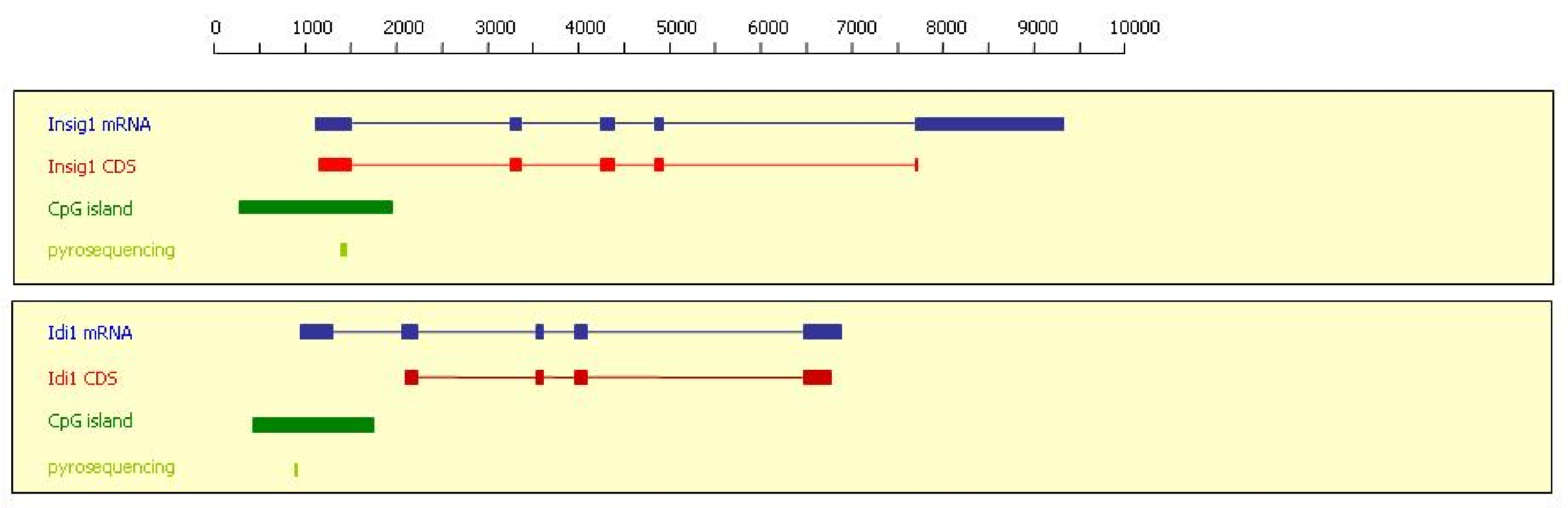

TXnip mRNA
TXnip CDS
Cyg island


A

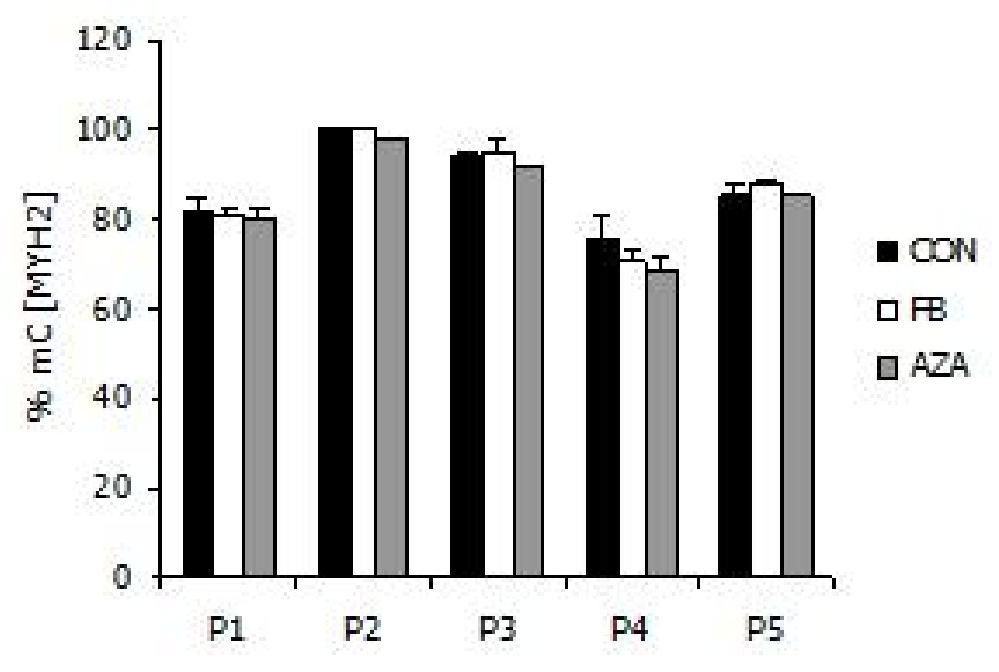

C

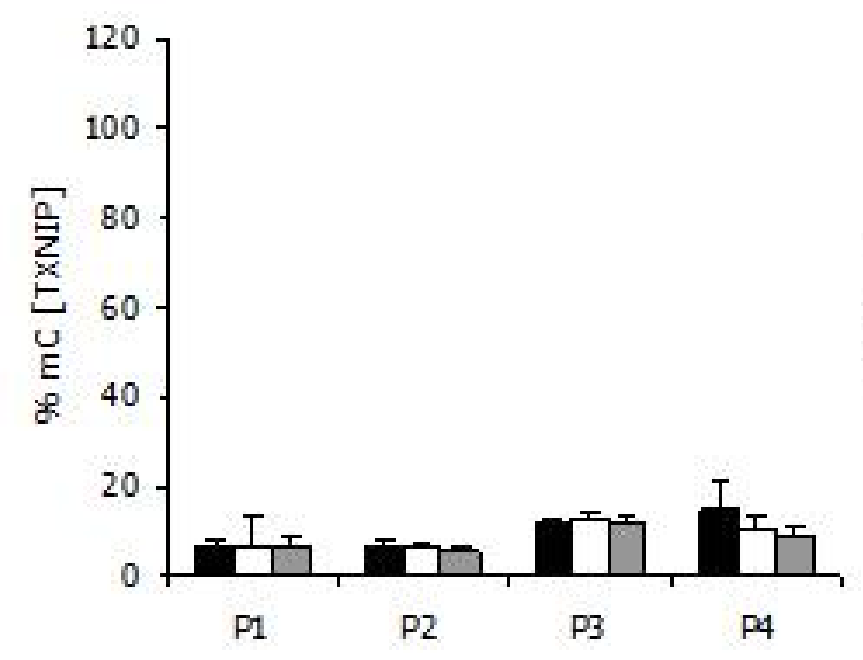

B

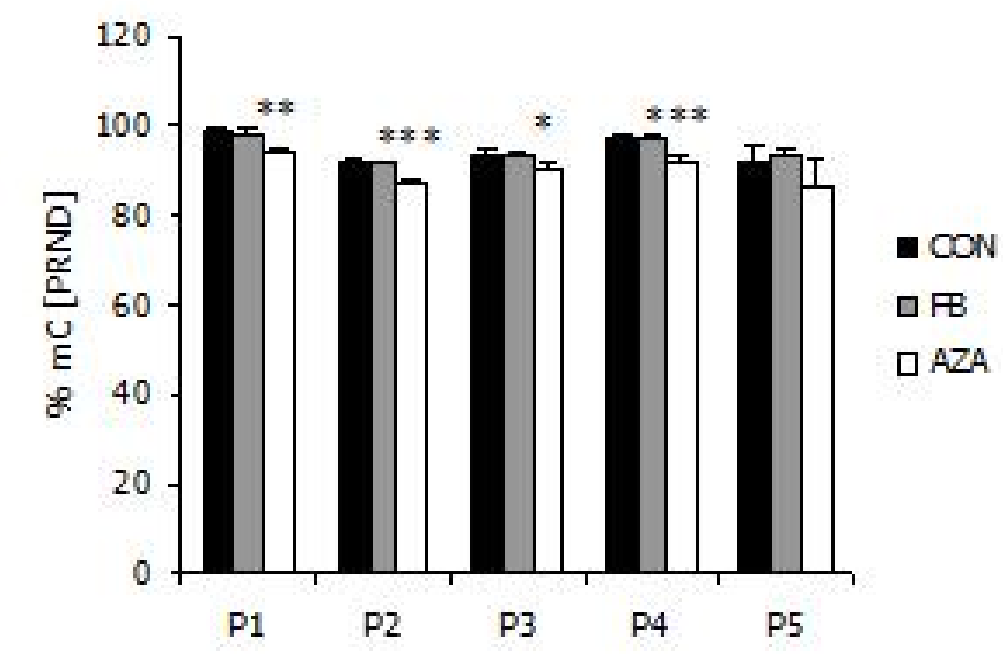

D

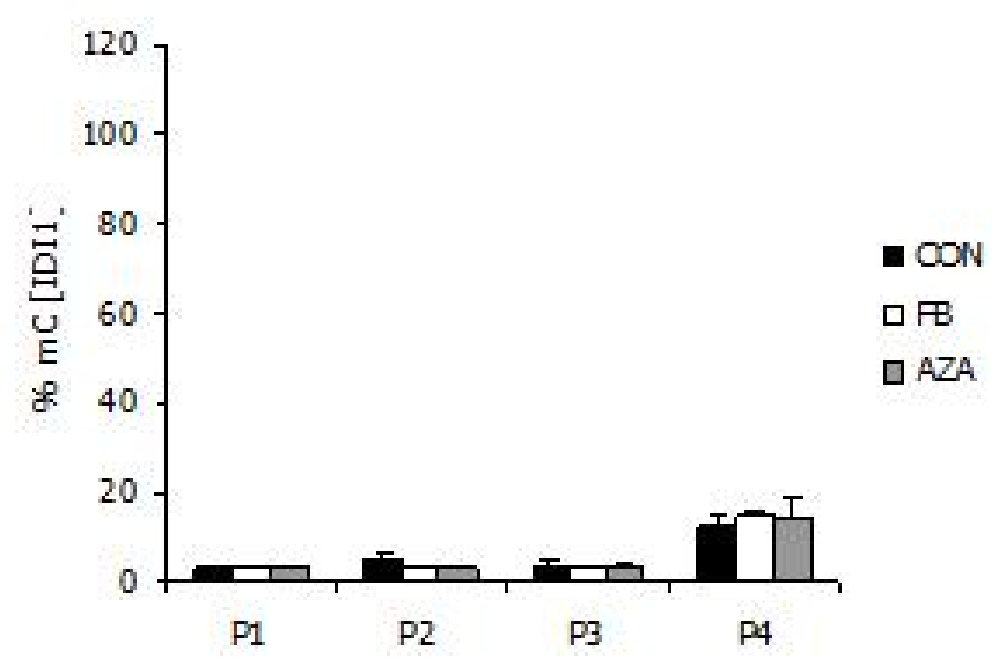

